\title{
Indução de tolerância nasal com colágeno tipo V em modelo experimental de esclerodermia
}

Tese apresentada à Faculdade de Medicina da Universidade de São Paulo para a obtenção do título de Doutor em Ciências

Área de Concentração: Reumatologia

Orientador: Prof. Dr. Natalino Hajime Yoshinari 
Aos meus queridos pais Ilídio e Conceição, a quem devo tudo o que sou, dedico mais este trabalho e agradeço por toda dedicação, amor e incentivo e por terem me ensinado o sentido da vida, sendo meus primeiros mestres.

Ao meu amado esposo Carlos, companheiro que Deus colocou no meu caminho, por seu amor, paciência, compreensão, insentivo e auxílio em todos os momentos e por ter dado um novo brilho à minha vida.

Aos meus irmãos Bruno, Valéria e André pelo carinho, companheirismo e amizade em todos estes anos de convivência alegre e agradável.

Um agradecimento muito especial a Walcy Rosolia Teodoro, que com certeza posso chamar de amiga, por acreditar no meu potencial desde o início da minha carreira, sendo a principal incentivadora do meu ingresso no curso de pós-graduação e, principalmente, por sua capacidade criadora, que deu origem a mais este trabalho. Também, pela oportunidade de concretizar meu antigo sonho de trabalhar na área imunológica. 


\section{AGRADECIMENTOS}

Agradecer a todas as pessoas que, de algum modo, participaram deste trabalho é uma tarefa muito difícil, pois por menores que tenham sido as contribuições, todas foram fundamentais na realização deste estudo e no desenvolvimento do meu aprendizado.

A algumas destas pessoas, gostaria de deixar uma breve mensagem de gratidão:

Ao meu orientador Prof. Dr. Natalino Hajime Yoshinari, pela sua paciência, capacidade e apoio constante na realização de mais este trabalho e por me ensinar, como só fazem os mestres, a direcionar os meus pensamentos. Principalmente, por ter acreditado no meu potencial e novamente contribuir, com muita competência, para meu crescimento no campo profissional.

À Profa. Dra. Eloísa Silva Dutra de Oliveira Bonfá pela oportunidade dentro da Disciplina de Reumatologia da FMUSP e no curso de pósgraduação.

À Profa. Dra. Vera Luiza Capelozzi por sua amizade, paciência e disponibilidade, que com toda a sua competência e docilidade nos orientou e auxiliou na compreensão das alterações patológicas, ensinos fundamentais na realização deste trabalho. Também, por abrir um espaço valioso no Departamento de Patologia.

À Cristiane Carla de Oliveira e ao Rodnei Francisco Moutinho por sua amizade em todos estes anos de convivência alegre e pela participação e auxílio constantes na experimentação animal e ensaios laboratoriais, essenciais na realização deste estudo. 
Ao Antônio dos Santos Filho pela amizade em todos estes anos e pelo essencial auxílio na manipulação e experimentação animal. Principalmente por ter tratado com muita dedicação e carinho todas as coelhinhas envolvidas neste trabalho.

Ao Luciano e Romildo, cujo auxílio na manipulação e experimentação animal foram fundamentais para realização deste trabalho.

À Cássia Arruda, mestra na arte da histologia, pela sua incomparável disponibilidade, sempre pronta a colaborar na realização dos procedimentos histológicos. Principalmente pela sua amizade, paciência e compreensão nos momentos mais difíceis. Também, a todas as meninas do Laboratório de histologia do Departamento de Patologia que de algum modo contribuíram para a realização deste trabalho.

Ao Dr. Edwin Roger Parra pela amizade, disponibilidade e auxílio e por contribuir, com seus conhecimentos no campo da Palologia e estatística, na realização deste trabalho. Também, por seu auxílio na realização de muitas das fotografias presentes neste trabalho.

À Cleonice Bueno pela amizade em todos estes anos, pela paciência, pela disponibilidade e por orientar e auxiliar com tanta competência, na realização dos ensaios sorológicos.

À Margarete B. G. Vendramine pela amizade em todos estes anos, pela paciência e disponibilidade e por contribuir com toda a sua experiência na realização do FAN.

À Ângela Gomes Santos e Maria Cristina R. Medeiros do Laboratório de imunohistoquímica do Departamento de Patologia pela amizade e auxílio na realização das reações de imunofluorescência para o TGF- $\beta$ e o PDGF. 
À Fátima Abatepaulo e Sueli K. kubo Ariga pela amizade em todos estes anos e pela gentil realização da reação do TUNEL.

À Valéria Pereira Velosa, pelo auxílio profissional na revisão gramatical deste trabalho. E mesmo não sendo da área, pela paciência de ler este trabalho até o fim.

À Solange Carrasco pela amizade em todos estes anos, que embora não tenha contribuído diretamente com este trabalho, nos auxiliou no armazenamento dos vários órgãos dos animais e na cultura de fibroblastos de pele, que originarão vários outros trabalhos.

A tantas pessoas que diariamente entram e saem do Laboratório de Matriz Extracelular pela amizade, paciência e incentivo, entre elas gostaria de citar: as Pós-graduandas Luciana, Mailze, Sandra....; os alunos de Medicina, Mateus, Daniel, Guilherme,.....; as alunas de iniciação científica, Verônica, Dafne,...; os antigos aprimorandos que se tornaram nossos amigos, como a Martha Celle e muitos outros.

Às amigas da secretaria da Disciplina de Reumatologia, e em especial a Fátima...., pela paciência e orientação constantes nos procedimentos burocráticos da pós-graduação.

A todos os amigos da Disciplina de Reumatologia, pela amizade e por terem contribuído para o meu crescimento em todos estes anos de convivência.

Por fim, gostaria de agradecer a Deus pela graça da vida e por colocar no meu caminho pessoas fundamentais no meu desenvolvimento profissional e pessoal. Como sinal de agradecimento queria pedir a Ele que abençoe e proteja a todas estas pessoas. 


\section{SUMÁRIO}

Resumo

Summary

I - Introdução 1

1 - $\quad$ Aspectos gerais da Esclerose 1

1.1 - Etiologia e patogênese da Esclerose sistêmica 3

1.2 - Terapêutica em Esclerose sistêmica 12

2 - $\quad$ Modelos experimentais de Esclerodermia sistêmica 13

3 - $\quad$ Colágeno tipo V 18

3.1 - Auto-imunidade e colágeno tipo V 22

4 - Tolerância imunológica 25

4.1 - Tolerância nas mucosas $\quad 28$

4.1 .1 - Tolerância oral 30

4.1 .2 - Tolerância nasal 36

4.2 - Tratamento de doenças autoimunes e tolerância 38

II - Objetivos 42

III - Métodos 44

1 - Indução de Esclerodema-símile por imunização com Col V 44

2 - $\quad$ Indução de tolerância nasal com colágeno tipo V 45

3 - $\quad$ Biópsias de pele $\quad 45$

4 - $\quad$ Análise morfométrica 46

5 - Imunofluorescência para os colágenos tipos I, III e V, TGF- $\quad$ e PDGF $\quad 47$

6 - $\quad$ Estudo Morfológico 48

7 - TUNEL para tecidos fixados (Apoptose) 49

8 - $\quad$ Coleta de soro $\quad 49$

9 - $\quad$ ELISA para colágeno tipos I, III, IV e V 50

10 - Fator anti-nuclear (FAN) 51

IV - Resultados $\quad 52$

1 - Análise Macroscópica 52

2 - $\quad$ Análise Histológica 52

3 - $\quad$ Análise Quantitativa do Colágeno 56

4 - $\quad$ Análise da Imunodetecção dos tipos de Colágeno 59

5 - Análise Semi-quantitativa de Colágeno 65

6 - Túnel (apoptose) $\quad 65$

7 - $\quad$ Determinação dos Anticorpos dos Tipos I, III, IV e V 68

8 - $\quad$ Determinação de Anticorpos Antinucleares (FAN) 69 
$\begin{array}{lll}\text { V - Discussão } & 71\end{array}$

VI - Conclusões $\quad 86$

$\begin{array}{lll}\text { VII - } & \text { Referências bibliográficas } & 87\end{array}$

VIII - Apêndices 


\section{RESUMO}

Velosa APP. Indução de tolerância nasal com colágeno tipo $V$ em modelo experimental de esclerodermia [tese]. São Paulo: "Faculdade de Medicina, Universidade de São Paulo"; 2007. 112 p.

Objetivo: Verificar o remodelamento da pele e produção de anticorpos em modelo experimental de esclerodermia em coelhos, após indução de tolerância nasal com colágeno tipo $\mathrm{V}$. Métodos: Coelhas Nova Zelândia $(\mathrm{N}=12)$ foram imunizadas com $1 \mathrm{mg} / \mathrm{ml}$ de colágeno $\mathrm{V}(\mathrm{Col} \mathrm{V})$ em adjuvante completo de Freund e dois reforços com adjuvante incompleto de Freund. Seis coelhas imunizadas receberam uma dose diária de $25 \mu \mathrm{g}$ de Col $\mathrm{V}$, iniciado via nasal (grupo tolerado) 150 dias do começo das imunizações e seis animais foram somente imunizadas (grupo imunizado). Um grupo imunizado com adjuvante de Freund serviu como controle. Biopsias de pele foram coletadas em $0,75,120,150$ e 210 dias e coradas pelo H\&E, tricrômico de Masson e Sírius red para analise morfológica e morfométrica. Os colágenos I, III e V, além de TGF $\beta$ e PDGF foram imunomarcados por imunofluorescência. Os soros dos animais foram coletados em 0, 150 e 210 dias para determinar anticorpos anti-colágenos I, III, IV e V e anti-nucleares. Resultados: Os animais imunizados mostraram progressivo decréscimo da derme papilar, atrofia de anexos, aumento no depósito dos colágenos I, III e $\checkmark$ e aumento da expressão de TGF $\beta$ e PDGF. Os tolerados apresentaram aumento dos anexos cutâneos e significante diminuição no depósito dos colágenos I, III e V, TGF $\beta$ e PDGF. O grupo de imunizados e de tolerados apresentaram anticorpos anti-colágenos III e IV e antinucleares. Conclusões: A indução de tolerância nasal com Col $\vee$ diminuiu o remodelamento da pele observado no modelo experimental de esclerodermia e inibiu a síntese de citocinas fibrogênicas. Portanto, a tolerância nasal com Col $V$ pode ser uma opção terapêutica promissora para o controle do remodelamento cutâneo em pacientes com esclerodermia.

Descritores: Colágeno tipo $V$, Escleroderma sistêmico, Tolerância imunológica, Mucosa nasal, Modelos animais, Coelhos. 


\section{SUMMARY}

Velosa APP. Indução de tolerância nasal com colágeno tipo $V$ em modelo experimental de esclerodermia [thesis]. São Paulo: "Faculdade de Medicina, Universidade de São Paulo"; 2007. 112 p.

Objective: Our aim was to verify the skin remodeling and antibody production in experimental model of scleroderma in rabbits, after induction of tolerance by daily nasal administration of human type $\mathrm{V}$ collagen (Col $\mathrm{V}$ ). Methods: Female New Zealand rabbits $(\mathrm{N}=12)$ were immunized with $1 \mathrm{mg} / \mathrm{ml}$ of Col V in complete Freund's adjuvant, followed by more two boosters in incomplete Freund's adjuvant. Six immunized rabbits received daily nasal administrating of $25 \mu \mathrm{g}$ of Col $\mathrm{V}$ (tolerated group), started 150 days after the first immunization, and the others animals $(\mathrm{N}=6)$ were only immunized (immunized group). Finally a group of rabbits immunized with Freund's adjuvant served as control. Skin biopsies were collected at 0, 75, 120, 150 and 210 days, and stained with H\&E, Masson's trichrome and Sirius red for morphological and morphometric analysis. Types I, III and V collagen, TGF $\beta$ and PDGF were immunostained by immunofluorescence. The sera of animals were colleted at 0, 150 and 210 days to determine anti types I, III, IV and $V$ collagen and antinuclear antibodies. Results: The immunized animals showed progressive decrease of papillary dermis, appendages atrophy, increase of types I, III and V collagen deposition and increased expression of TGF- $\beta$ and PDGF. The tolerated rabbits presented increase of cutaneous appendages and significant decrease of types I, III and V and TGF- $\beta$ and PDGF. Both immunized and tolerated rabbits presented anti types III and IV antibodies and antinuclear antibodies. Conclusions: Col $\mathrm{V}$ nasal tolerance reduced skin remodeling in experimental model of scleroderma and inhibited synthesis of fibrotic cytokines. Therefore, the nasal tolerance with type $\mathrm{V}$ collagen can be a promising therapeutic option to control the skin remodeling in patients with scleroderma.

Descriptors: Type $V$ collagen, Systemic sclerosis, Immunologic tolerance, Nasal mucous, Animal models, Rabbits 


\section{I - Introdução}

\section{1- Aspectos gerais da Esclerose sistêmica}

A Esclerose sistêmica (ES) ou esclerodermia é uma doença reumática autoimune grave, de etiologia desconhecida, caracterizada por lesão de células endoteliais, proliferação da camada fibroíntima dos vasos e síntese excessiva de colágeno, resultando em fibrose de pele e órgãos internos, além da produção de auto-anticorpos. A incidência desta enfermidade está entre 4,5-18,7 novos casos por milhão de habitantes nos USA e países da Europa (Gaubitz, 2006). Esta doença é mais comum entre os 30-50 anos de idade, sendo incomum em crianças menores de 13 anos. Como ocorre em outras desordens do tecido conjuntivo, a ES é também predominante no sexo feminino, encontrando-se numa proporção entre 5 a 14 mulheres para 1 homem. As diferentes etnias influenciam na sobrevida e manifestações da doença, como, por exemplo, a progressiva fibrose intersticial pulmonar, que ocorre com menos freqüência em pacientes caucasianos, quando comparados aos afro-americanos e japoneses (Gaubitz, 2006).

A ES é classificada em limitada ou difusa, tendo como base o grau de extensão do envolvimento cutâneo. Os pacientes com esclerodermia 
limitada têm o espessamento cutâneo restrito às regiões distais, como mãos, pés, face e pescoço, porém sem envolvimento do tronco. Dentro deste grupo inclui-se a síndrome CREST, com acometimento cutâneo da face e extremidades, presença de calcinose, fenômeno de Raynaud, alterações da motilidade do esôfago e telangiectasias. Já os pacientes com a doença difusa apresentam espessamento de pele envolvendo a região do tronco, usualmente peito, abdômen e costas. Embora o componente cutâneo seja o principal fator na distinção dos dois tipos de ES, outras características são consideradas, como apresentado na tabela-1.

Tabela 1 - Principais características encontradas nas formas limitada e difusa de ES (Vilas et al., 2002).

\section{ES limitada}

ES difusa

\begin{tabular}{|c|c|c|}
\hline Fenômeno de Raynaud & $\begin{array}{l}\text { Surge muitos anos } \\
\text { (décadas) antes das } \\
\text { outras manifestações. }\end{array}$ & $\begin{array}{l}\text { Entre o seu aparecimento } \\
\text { e o aparecimento das } \\
\text { outras manifestações da } \\
\text { ES, cursa habitualmente } \\
\text { menos de } 1 \text { ano. }\end{array}$ \\
\hline Telangiectasias & Freqüentes. & $\begin{array}{l}\text { Podem surgir em fases } \\
\text { avançadas da doença. }\end{array}$ \\
\hline $\begin{array}{l}\text { Calcificações } \\
\text { subcutâneas }\end{array}$ & Freqüentes. & $\begin{array}{l}\text { Podem surgir em fases } \\
\text { avançadas da doença. }\end{array}$ \\
\hline Atritos tendinosos & Raros. & Freqüentes. \\
\hline $\begin{array}{l}\text { Envolvimento de órgãos } \\
\text { internos }\end{array}$ & $\begin{array}{l}\text { Ocorre tardiamente e com } \\
\text { menos freqüência que na } \\
\text { forma difusa. }\end{array}$ & $\begin{array}{l}\text { Ocorre mais } \\
\text { precocemente e com } \\
\text { maior freqüência que na } \\
\text { forma limitada. }\end{array}$ \\
\hline Marcadores sorológicos & Anti-centrômero (70-80\%). & $\begin{array}{l}\text { Anti-Scl-70 (até 30\%) dos } \\
\text { casos. }\end{array}$ \\
\hline Capilaroscopia ungueal & $\begin{array}{l}\text { Dilatação dos capilares, } \\
\text { sendo pouco freqüente a } \\
\text { perda de alças capilares. }\end{array}$ & Perda de alças capilares. \\
\hline $\begin{array}{l}\text { Principal causa de } \\
\text { morte }\end{array}$ & Hipertensão pulmonar. & Alveolite fibrosante. \\
\hline
\end{tabular}




\section{1 - Etiologia e patogênese da Esclerose sistêmica}

A etiologia da ES é ainda desconhecida. Entretanto, alguns fatores ambientais, tais como exposição a substâncias químicas, estímulos mecânicos e viroses, aumentam o risco do desencadeamento desta doença. Entre os agentes químicos destacam-se a sílica, o benzeno, o tolueno, o tricloroetileno, o hexacloroetano, além de drogas como a bleomicina, a pentazocina e o L-triptofano contaminado (Wigley, 1999). Os fatores genéticos podem, também, estar relacionados com a etiologia desta doença, havendo um risco maior para o desenvolvimento da ES em indivíduos com presença de histórico familiar. O microquimerismo desencadeado pela passagem de células maternas aos filhos é também considerado como possível causa de ES (Figura 1).

Na ES, o endotélio é o alvo de uma agressão imune-inflamatória, que resulta em desregulação do controle do tônus vascular e progressiva desorganização da arquitetura vascular, além de proliferação de células endoteliais, espessamento da camada íntima e oclusão vascular. Estes fatos resultam no aumento da permeabilidade vascular e formação do infiltrado inflamatório, contribuindo para a iniciação da fibrose. A disfunção endotelial vascular em ES é caracterizada pelo aumento de mediadores vasoconstritivos endoteliais, como a endotelina-1, e decréscimo da produção de prostaciclina, um vasodilatador derivado do endotélio, sendo que o papel da produção de NO (óxido nítrico) pelo endotélio ainda não está bem definido (Figura -1). 
A produção excessiva de proteínas da matriz extracelular, como os colágenos tipos I, III, V, VI e VII, a tenascina, as proteoglicanas, a fibronectina, a laminina e a fibrilina-1, pelos fibroblastos é o ápice da patogênese da ES. O acúmulo de colágeno resulta das interações anormais entre células endoteliais, células mononucleares (linfócitos e monócitos) e fibroblastos, acarretando na produção de citocinas que induzem à fibrose, num contexto de hiperreatividade vascular e hipóxia do tecido (Tamby et al., 2003) (figura 1). Os miofibroblastos, os quais se diferenciam de fibroblastos na presença de trombina, são os responsáveis pela aumentada produção de colágeno (Bogatkevich et al., 2001). A síntese de colágeno é dependente de várias citocinas, como o TGF- $\beta$ (Fator de crescimento de transformaçãobeta), produzido pelos fibroblastos e células endoteliais, e o CTGF (Fator de crescimento do tecido conectivo), sintetizado pelos fibroblastos sob a influência de TGF- $\beta$. Deste modo, em ES, o TGF- $\beta$ tem um papel importante na iniciação e desenvolvimento da fibrose (Querfeld et al., 1999), sendo o CTGF o principal responsável pelas lesões fibróticas (Bordon et al., 1998). Os fibroblastos de indivíduos com ES produzem grandes quantidades de interleucina (IL)-6, IL-8 e PDGF (Fator de crescimento derivado das plaquetas), os quais contribuem para o aumento da síntese de matriz extracelular de maneira autócrina (Mouthon et al., 2002). O PDGF também pode estimular a síntese de MCP-1 (proteína quimiotática de monócitos) pelos fibroblastos que, por sua vez, aumentam a síntese de colágeno tipo I, além de aumentar a transmigração endotelial de células mononucleares (Mouthon et al., 2002). A atividade aumentada de gelatinase em fibroblastos 
dérmicos de ES poderia ser a responsável pelo início da lesão microvascular e pela liberação de substâncias capazes de aumentar a lesão de células endoteliais ou ativação de fibroblastos (Fakhoury, 2002) (Figura-1).

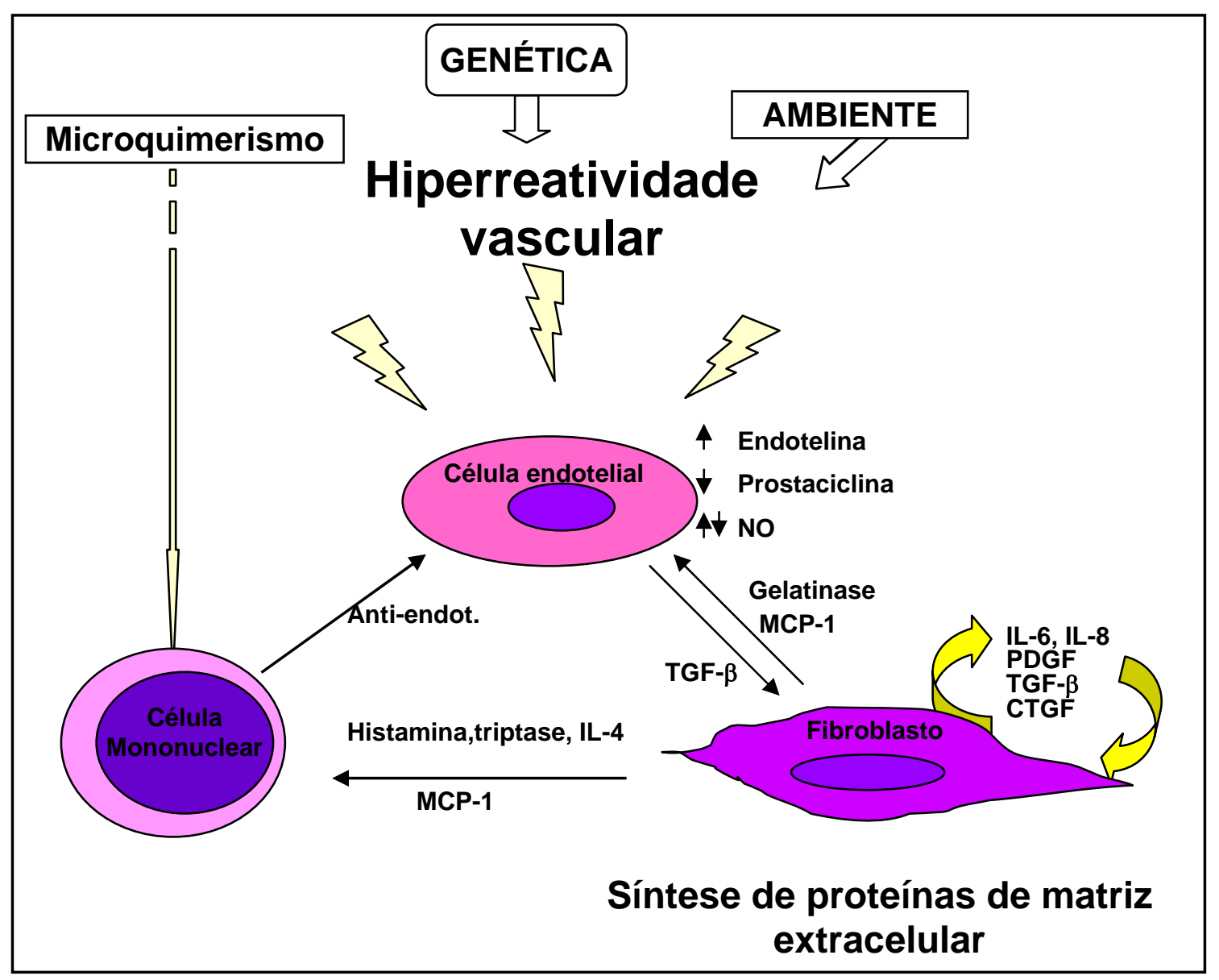

Figura 1 - Diagrama esquemático da fisiopatologia da ES, de acordo com Tamby e col., 2003.

Alguns trabalhos na literatura sugerem que a apoptose de células endoteliais seja um evento patológico primário na ES (Sgonc, 1996; Bordon et al., 1998; Jun et al., 2003), possivelmente desencadeado, como mencionado acima, por viroses, substâncias tóxicas, entre outros. Recentemente, Laplante et al. (2005) estudaram alguns dos mecanismos 
que ligam a apoptose de células endoteliais à fibrose. Estes autores sugerem que células endoteliais apoptóticas desencadeiam a liberação de mediadores solúveis antiapoptóticos, incluindo um fragmento do domínio $\mathrm{V}$ do perlecam, o qual induz a resistência à apoptose em fibroblastos. Foi sugerido que certas porções presentes neste fragmento C-terminal do perlecam podem estimular a inibição de apoptose em fibroblastos através da indução de PI3K, o qual parece assumir um papel central neste processo (Figura 2). O PI3K age tanto na inibição de apoptose em fibroblastos, através da modulação seqüencial dos níveis das proteínas Bim-EL e Bcl-X $\mathrm{X}_{\mathrm{L}}$, como na diferenciação de fibroblastos em miofibroblastos, os quais expressam $\alpha$-SMA e grande produção de colágeno e outras proteínas da matriz extracelular, que culmina, a longo tempo, em fibrose (Figura 2). Ainda, foi demonstrado que fibroblastos provenientes de lesões de pele de pacientes com ES são mais sensíveis à ação destes mediadores solúveis antiapoptóticos, produzidos pelas células endoteliais apoptóticas, quando comparados com os fibroblastos provenientes de pele normal (Laplante et al. 2005). 


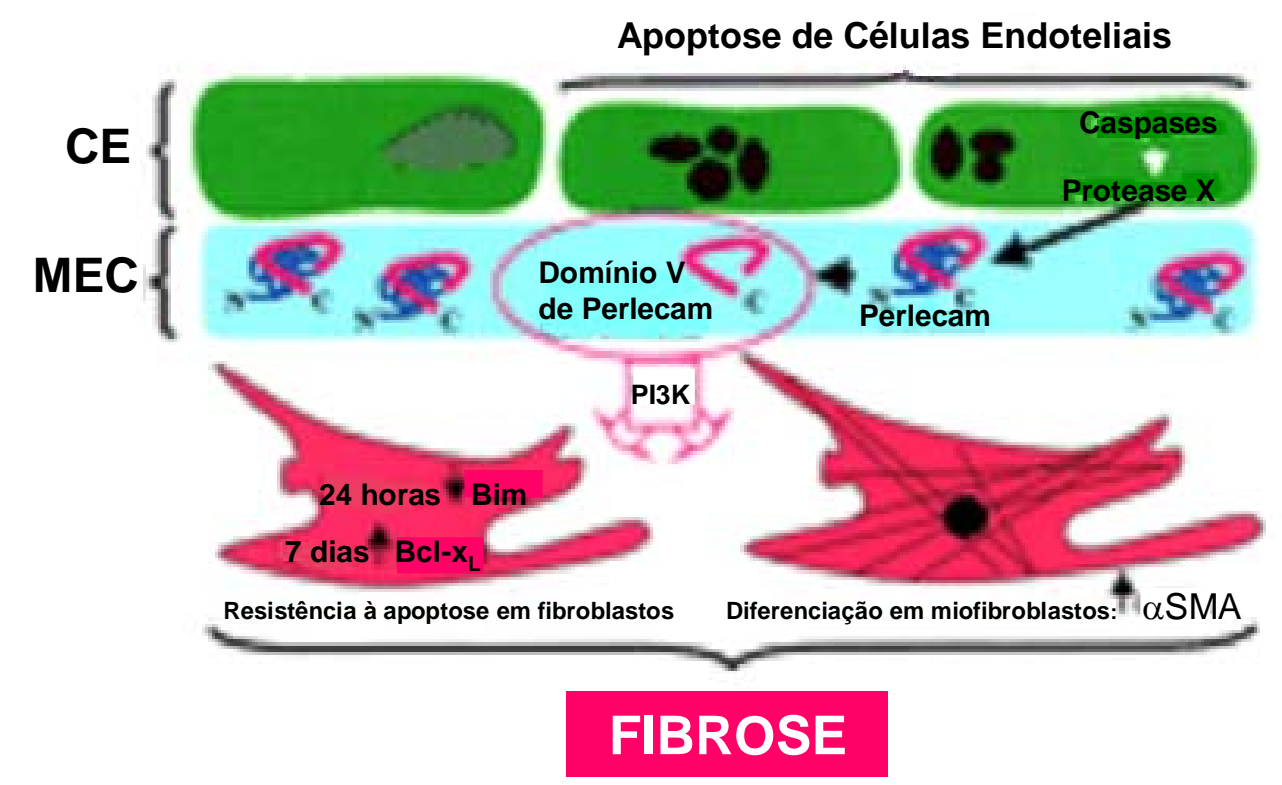

Figura 2 - Diagrama esquemático. A apoptose de células endoteliais desencadeia a liberação de mediadores solúveis, o qual inclui o fragmento C-terminal do Perlecam. Este, por sua vez, ativa o PI3K em fibroblastos levando-os à resistência a apoptose, sequencialmente regulada pelos níveis das proteínas Bim-EL e Bcl-xL e para a diferenciação em miofibroblastos. Porém, a produção crônica destes mediadores pode levar à fibrose. CE, células endoteliais; MEC, matriz extracelular. (Laplante et al., 2005)

Outra característica importante na ES é a presença de autoanticorpos no soro dos pacientes; entretanto, seu papel patogênico ainda continua incerto. Três destes auto-anticorpos são específicos da doença e mutuamente exclusivos, como os anticorpos anti-centrômero (ACA), antitopoisomerase 1 (ATA) e anti-RNA polimerase (RNAP) III. A topoisomerase I é uma proteína básica nuclear não histona, com peso de 110 KDa, envolvida na regulação do DNA. Os anticorpos anti-topoisomerase 1, ou Scl-70, estão presentes no soro de cerca de $30 \%$ dos pacientes com ES difusa (Steen et al., 1988) e estão fortemente associados com o risco de desenvolvimento de pneumopatia infiltrativa (Diot et al., 1999). Os anti-centrômero, os quais se 
ligam principalmente às proteínas do centrômero (CENP-A, B e C), são detectados em $20-40 \%$ dos pacientes com ES, sendo mais freqüentes naqueles com a forma limitada (Ferri et al., 2002). Já os anti-RNA polimerase III ligam-se às RNA polimerase I e III, que são enzimas envolvidas na transcrição do DNA. Estes auto-anticorpos são encontrados em 4-33\% dos pacientes com ES difusa, em associação com envolvimento renal, e representam um marcador de piora do prognóstico (Okano et al., 1993).

Outros auto-anticorpos, também encontrados em outras doenças auto-imunes, direcionados contra diferentes estruturas nucleares, do citoplasma e da membrana citoplasmática, componentes da matriz extracelular, fibroblastos e/ou células endoteliais, foram identificados em pacientes com ES. Alguns deles são os anticorpos anti-endotélio, detectados em $40 \%$ dos pacientes com ES difusa e em 13,8\% com ES limitada, em associação com isquemia digital, fibrose pulmonar e envolvimento cardíaco (Negi et al., 1998). Auto-anticorpos para colágeno são detectados em um terço dos pacientes com ES, particularmente nos estágios iniciais da doença. A presença de anticorpos anti-colágeno tipo I foi encontrada em 40\% dos pacientes com ES (Mackel et al. 1982). Além disso, anticorpos anti-colágeno dos tipos IV e $\mathrm{V}$ também foram descritos em pacientes com ES (Mackel et al., 1982; Riente et al., 1995), sendo sugestivo de lesão na membrana basal.

Recentemente, tem sido sugerida a importância das células mononucleares, principalmente os linfócitos, na patogênese da 
esclerodermia. Existem várias evidências que sugerem a importância das células T na patogênese da ES. Estas células foram detectadas nas fases iniciais da ES na pele de pacientes, antes do desenvolvimento da fibrose (Prescott et al., 1992). Além disso, a freqüência de células $T$ ativadas no sangue e lesões de pele dos pacientes é aumentada. Estas células T são principalmente do subtipo Th2, as quais produzem interleucina 4 (II-4), citocina que induz a produção de colágeno pelos fibroblastos, além de estimular a produção de TGF- $\beta$, um potente mitógeno para fibroblastos. Outro aspecto importante é o fato das células T serem necessárias para a produção de anticorpos, como o anti-topoisomerase 1 (Kuwana et al., 1995), o qual, juntamente com outros auto-anticorpos, é característico de ES.

Algumas evidências adicionais do envolvimento das células T em ES se referem às semelhanças das características clínicas e patológicas, incluindo o perfil sorológico (Bell et al., 1996), entre a doença de enxerto versus hospedeiro $(D E V H)$ e a ES. A DEVH é mediada por células T ativadas e pode se manifestar como uma doença escleroderma-símile (Bell et al., 1996). Vários tratamentos propostos com o intuito de inibir as células T em ES têm tido um efeito benéfico para os pacientes, revelando a importância destas células na patogênese da doença (Clements et al., 1996; Morton e Powell, 2000). Além disso, foram identificadas células T infiltrantes em lesões de pele, contendo linfócitos $\mathrm{T}$ oligoclonais dirigidos para um antígeno específico, ainda não reconhecido (Sakkas et al. 2002).

De acordo com essa teoria, as células $\mathrm{T}$ podem ser ativadas $\mathrm{e}$ proliferar de maneira não específica, em resposta à presença de quimocinas, 
citocinas ou mitógenos ou em resposta a algum antígeno específico desconhecido. Sugere-se a participação de vários destes antígenos, tais como: HLA de origem fetal ou materna (Arnett, 1995; Artlett et al., 2000); DNA de topoisomerase I (Muryoi et al., 1992; Kuwana et al., 1993); fibrilina (Arnett et al., 1996); centrômero (Rattner et al., 1996); RNA polimerase e outros antígenos nucleares (Pollard et al., 1989; Overzet ae al., 2000); citomegalovírus (Neidhart et al., 1999; Pandey e Leroy, 1998) e retrovírus (Jimenez e Batuman, 1993).

As células $\mathrm{T}$ ativadas e as citocinas que elas produzem explicam as três principais características da ES, como a indução de fibrose, a proliferação fibroíntima microvascular e a produção de auto-anticorpos (figura 3).

As células $\mathrm{T} \mathrm{CD}^{+}$, do subtipo Th2, são as principais produtoras de IL4, a qual promove a produção de colágeno pelos fibroblastos (Fertin et al., 1991; Postlethwaite et al., 1992), além de TGF- $\beta$ por monócitos/macrófagos (Seder et al., 1998; Mcgaha et al., 2001). Este último também induz a proliferação de fibroblastos e a produção de colágeno e CTGF (Fator de crescimento do tecido conectivo) (figura 3). O CTGF, por sua vez, aumenta significativamente a síntese de colágeno e fibronectina e promove o substancial remodelamento da matriz extracelular. 


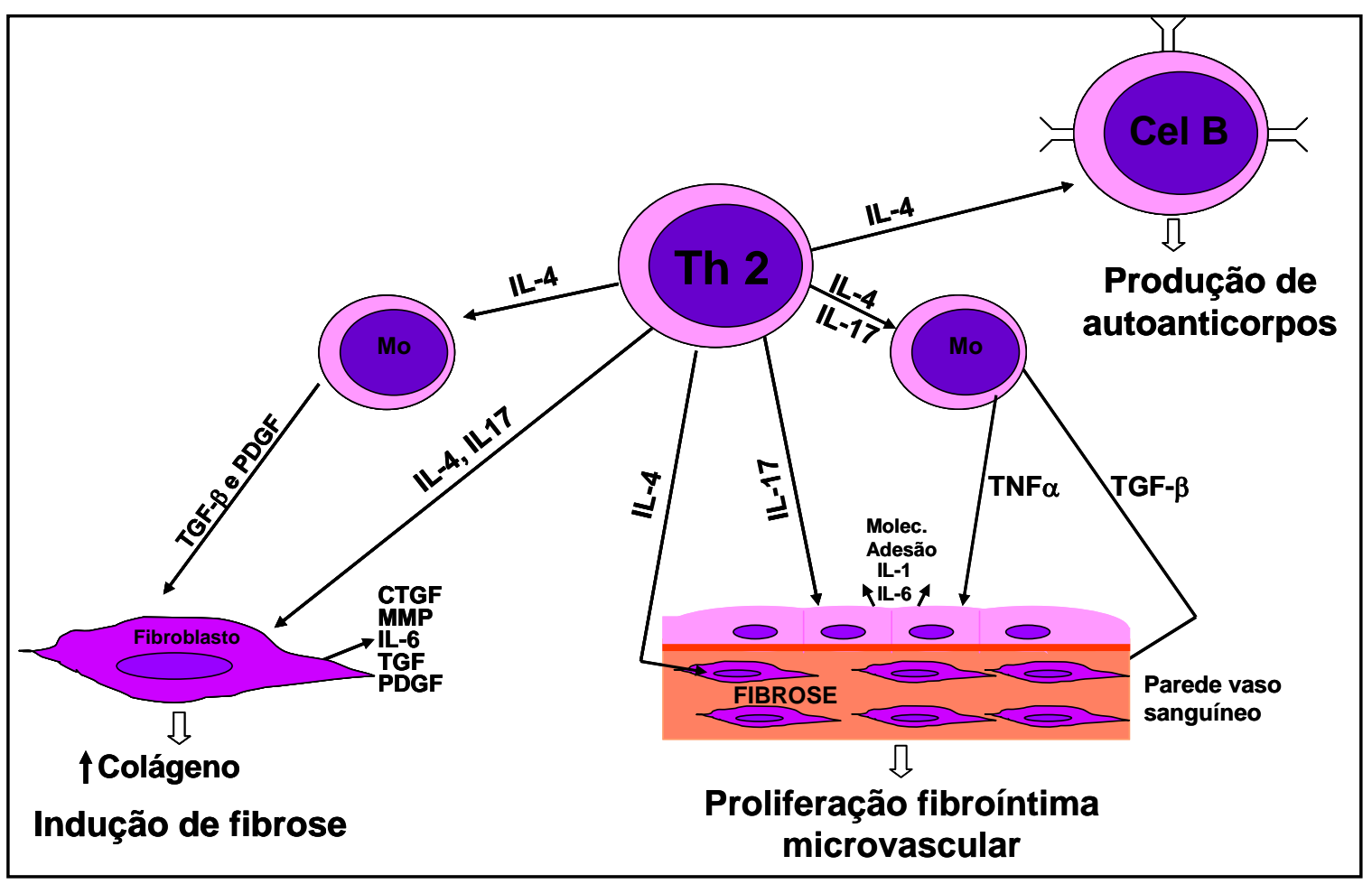

Figura 3 - Diagrama esquemático mostrando o envolvimento das células T (Th2) e das citocinas produzidas por estas células (IL-4 e IL-17) na síntese de colágeno e indução de fibrose, proliferação da camada fibroíntima microvascular e produção de auto-anticorpos em esclerose sistêmica. Mo, monócitos; Th2, linfócitos T do subtipo Th2; Cel B, linfócitos B. (Esquema baseado em Sakkas e Platsoucas, 2004).

A proliferação da fibroíntima microvascular pode ser conseqüência da liberação de IL-4 e IL-17 pelas células T ativadas. Estas citocinas causam a hiperplasia de fibroblastos pelo aumento de TGF- $\beta$ (Seder et al., 1998; Mcgaha et al., 2001), que, consequentemente, induz os fibroblastos a secretar colágeno e CTGF (Sato et al., 2000; Shi-Wen et al., 2000) (Figura 3). A expressão de moléculas de adesão na superfície das células endoteliais permite que o infiltrado inflamatório mononuclear atravesse a camada endotelial, para o espaço perivascular, contribuindo no dano vascular observado nesta estrutura na ES. 
$\mathrm{Na}$ ES, a produção de alguns auto-anticorpos, como a antitopoisomerase I, pelos linfócitos B, é dependente de células T. Além disso, alguns auto-anticorpos, como os anti-fibroblastos e anti-endotélio, parecem induzir a produção de IL-1, após a ligação destes com suas respectivas células (Figura 3).

\section{2 - Terapêutica em Esclerose sistêmica}

Devido ao fato da ES ser uma doença de etiologia desconhecida e de patogênese não bem esclarecida, esta não possui, ainda, nenhum tratamento específico e que resulte, portanto, na cura da doença. Entretanto, existem alguns fármacos que são eficazes no controle de algumas manifestações da doença. Normalmente a terapêutica consiste na inibição das alterações vasculares, imunológicas e da fibrose. Para as alterações vasculares, como o fenômeno de Raynaud, presente na extremidade dos membros, como medidas gerais, são procedimentos aconselháveis: evitar o frio (usar luvas, não mergulhar as mãos na água fria), o "stress", o tabaco e os fármacos vasoconstritores. Além disso, podem ser utilizados vasodilatadores tópicos ou orais, como os bloqueadores dos canais de cálcio e anti-agregantes plaquetários. Em casos de isquemia grave, são indicados os análogos da prostaciclina endovenosos ou, em último caso, a anticoagulação. A simpatectomia seletiva das artérias digitais pode ser considerada quando as medidas anteriores não forem eficazes e na presença de isquemia muito grave (Wigley, 1999; Vilas et al., 2002). As terapêuticas imunossupresivas para ES consistem no emprego de drogas 
mais seletivas, como a ciclosporina, que inibe a ação das células T auxiliares pela redução da liberação de IL-2, reduzindo assim a síntese de colágeno; e a imunossupressão não seletiva, como o metotrexate, antagonista do ácido fólico, e a ciclofosfamida (Wigley, 1999). Outras drogas são utilizadas no controle da fibrose na ES, como a D-penicilamina, que inibe a formação de colágeno com ligações cruzadas estáveis, os interferons $\alpha$ e $\gamma$, que inibem a produção de colágeno por fibroblastos dérmicos, e a colchicina, que inibe a produção de colágeno pela ruptura dos microtubos no citoesqueleto dos fibroblastos, além de possivelmente aumentar a atividade de colagenases (Wigley, 1999).

Entretanto, várias destas drogas, além de não proporcionarem a cura da doença, podem causar efeitos colaterais, como cefaléia, depressão medular, crise renal, entre outros. Ainda são necessários vários estudos controlados, para se ter uma idéia mais precisa dos efeitos de muitas destas terapias.

\section{2 - Modelos experimentais de Esclerose sistêmica}

Os modelos experimentais de ES têm sido de grande valia na compreensão da patogênese desta complexa doença. Entre eles, estão descritos os modelos associados com o desenvolvimento espontâneo de alterações semelhantes à ES, por defeito genético, como o modelo em murinos TSK-1/+ e galinhas UCD-200 (Sgonc, 1999; Saito et al., 2002; Abraham e Varga, 2005). No modelo do TSK-1/+ em murinos, ocorre a duplicação do gene da fibrilina-1, o qual predispõe ao desenvolvimento de 
fibrose. Vários aspectos da ES são encontrados neste modelo, como alterações vasculares, auto-imunidade e fibrose, porém não foi observada inflamação (Saito et al., 2002). Já o modelo em uma linhagem hibrida de galinhas UCD-200, revela um proeminente envolvimento vascular, com infiltrado inflamatório agudo e fibrose amplamente distribuída (Sgong, 1999).

Existem também os modelos geneticamente manipulados, através de mutagênese ou modificações genéticas (Clark, 2005; Denton et al., 2005), como o TSK-2/+ em murinos. Este modelo resulta de uma mutação induzida no braço proximal do cromossomo 1 (Peters e Ball, 1986). Esta mutação é autossômica dominante, sendo que o homozigoto TSK-2/TSK-2 não é viável. Os camundongos TSK-2/+ desenvolvem uma série de anormalidades histopatológicas e bioquímicas similares às encontradas na pele de pacientes com ES, incluindo o aumento no conteúdo de colágeno tipo I (Christner et al., 1995). Esses camundongos desenvolvem um grande infiltrado mononuclear na camada inferior da derme e no septo do tecido adiposo (Christner et al., 1995). Além disso, é encontrada uma alta freqüência de anti-Scl70 e anti-centrômero, indicando que este modelo desenvolve várias alterações humorais similares às verificadas em pacientes com ES (Gentiletti et al., 2005).

Alguns modelos são induzidos experimentalmente por exposição a substâncias químicas, como a bleomicina (Yamamoto e Nisshioka et al., 2005), que induz fibrose pulmonar, devido à produção local de oxigênio reativo, causando a lesão de células endoteliais, expressão de moléculas de adesão e apoptose de células mononucleares (Yamamoto e Nisshioka et al., 
2005). Outra substância tóxica capaz de induzir ES é o cloreto de vinila, solvente que ativa microquimerismo e está associado com o desenvolvimento de inflamação dérmica e fibrose (Cristner, 2000).

Outros modelos de ES se desenvolvem após transplante de células imunes, originando doença enxerto versus hospedeiro, com manifestações semelhantes à ES (Zhang e Gilliam, 2002). A transferência de células esplênicas de camundongos B10.D2 para animais Balb/C irradiados, induz a fibrose de pele e pulmão e infiltrados de células $T$, monócitos e macrófagos (Zhang e Gilliam, 2002). Já a transferência de células esplênicas de camundongos B10.D2 para camundongos Rag-/- induz fibrose sistêmica, inflamação e desenvolvimento de auto-anticorpos (Ruzek et al., 2004).

Recentemente, descobrimos um interessante modelo experimental de ES, induzido em coelhas sadias, Nova Zelândia, através da imunização com colágeno tipo $\mathrm{V}$ humano ( $\mathrm{COL} \mathrm{V}$ ) com adjuvante de Freund. Os animais imunizados desenvolveram alterações histológicas progressivamente piores, caracterizadas por lesões nas células endoteliais e fibrose na camada íntima do vaso, em todos os órgãos normalmente acometidos nesta doença (Yoshinari et al., 2002; Teodoro et al., 2003; Teodoro et al., 2004; Bezerra et al., 2006).

Duas características notáveis foram identificadas neste modelo. Primeiro, o remodelamento cutâneo foi muito precoce, sendo observado após sete dias da primeira imunização com COL V. A segunda característica foi o surgimento tardio de anticorpos nos animais imunizados, incluindo a presença de anticorpos antinucleares (FAN), anticorpos para proteínas do 
complexo de Golgi, identificados pelo imunoblot e presença de anticorpos anti-colágeno dos tipos I, III e IV (Yoshinari et al., 2005).

Adicionalmente, estudos histológicos e imunohistoquímicos realizados em pulmões e tecidos da pele de animais imunizados e pacientes com ES revelaram grandes similaridades (Souza et al., 2005). Estas semelhanças também foram reproduzidas com a cultura de fibroblastos de pele e pulmão de animais e pacientes com ES, pelo método de "explant" (Souza et al., 2005).

Tanto em animais como em pacientes com ES, além do aumento da síntese de colágenos, foi identificada a presença de COL V estruturalmente anômala, depositada em vários tecidos. Normalmente, esta fibra apresenta discreta marcação por imunoflurescência, formando longas e finas fibras. Este padrão morfológico habitual de COL V esteve muito diferente, tanto nos tecidos quanto nas culturas de animais imunizados e pacientes com esclerodermia. Esta molécula esteve expressa anormalmente, formando fibras mais curtas e espessas com distribuição heterogênea. Esta alteração no fenótipo do COL V, observada no modelo experimental e em pacientes com SSc, é uma descoberta original e de grande relevância, na medida que esta molécula participa do processo de fibrilogênese, ajudando a manter a integridade da matriz extracelular e regulando o diâmetro das fibras de colágeno (Bezerra et al., 2006).

O modelo experimental de ES induzido em coelhos por imunização com COL V é uma fascinante descoberta por diversas razões. Primeiro, ele é facilmente reproduzível em coelhos saudáveis, da linhagem Nova 
Zelândia, não modificados geneticamente, sugerindo que fatores exógenos, como os ambientais, possam estar fortemente implicados na patogênese da ES. Segundo, a existência de inúmeras semelhanças histológicas e sorológicas, entre o modelo experimental e os observados em pacientes com ES. Mais ainda, existe grande concordância nas alterações morfológicas, conforme o tecido analisado. Por exemplo, a observação de intenso processo inflamatório em pulmões ou exuberante remodelamento sinovial devido à fibrose foram aspectos comuns exibidos em animais e pacientes com ES. Terceiro, a lesão tecidual caracterizada por dano endotélial, proliferação de fibroíntima e depósito de colágeno, além de aspectos comuns, foram progressivas e, no caso dos coelhos, houve piora histolóica, mesmo após o termino das imunizações. Quarto, o aparecimento tardio de anormalidades imunológicas sugere que a resposta auto-imune foi gerada durante o processo inflamatório, induzido pelo COL V. Este aspecto é particularmente interessante, pois comprova que animais sadios, sob determinados estímulos exógenos, provavelmente em condições especiais, passam a desenvolver disfunção autoimune. Quinto, a histoarquitetura tecidual anômala, devido ao intenso remodelamento matricial resultante do aumento de colágenos e outras proteínas matriciais, é similar no modelo experimental e em humanos com ES. Mais ainda, em ambas as condições observa-se expressão estrutural atípica do colágeno tipo $\mathrm{V}$, principal molécula implicada no mecanismo da fibrilogênese (Bezerra et al., 2006).

Devido aos argumentos citados, este modelo animal é um instrumento muito importante para entender a patogênese da SSc, particularmente nos 
aspectos relacionados aos processos de sinalização e transcrição envolvendo ativação de fibroblastos e síntese de proteínas. Descobrir as causas que levam fibroblastos a se ativarem e sintetizarem quantidades aumentadas de proteínas, incluindo produção de colágeno $\mathrm{V}$ atípico, seria a forma de entender a patogênese e propor adequado tratamento desta grave enfermidade. Uma vez que o fenótipo dos fibroblastos pode ser modificado neste modelo experimental, através da introdução de uma proteína "self", e havendo similaridades morfológicas entre o modelo induzido de ES e o espontâneo, podemos postular que a esclerodermia, seja uma enfermidade autoimune dirigida aos constituintes próprios, possivelmente gerada durante prolongados processos inflamatórios (Denton e Abraham, 2004; Denton et al., 2005; Clark, 2005).

\section{3 - Colágeno tipo V}

O colágeno tipo $\mathrm{V}$, juntamente com os tipos I, II, III e XI, pertence à família dos colágenos que formam fibrilas (Gelse et al., 2003). Este é quantitativamente o menor componente dos tecidos ricos em fibras heterotípicas, tais como derme, tendões, ligamentos, ossos, vasos sanguíneos, representando cerca de 1 a 3\% do total de fibras de colágeno; na córnea, porém, sua concentração é relativamente maior, entre 20 a 25\% (Birk, 2001). O COL V se copolimeriza com os tipos I e III para formar fibrilas heterotípicas (I/III/V). Dessa forma, a porção tripla hélice helicoidal da

molécula de COL V encontra-se oculta no interior destas fibrilas e, por outro lado, o domínio globular amino terminal se projeta para a superfície (Birk, 
1990; Lisenmayer et al., 1993) (Figura 4). Este domínio regula o crescimento fibrilar, impedindo fisicamente que novos monômeros se acrescentem à fibrila. Devido a esta característica o colágeno tipo $\mathrm{V}$ tem função importante na organização, crescimento e dimensionamento do diâmetro das fibrilas heterotípicas (Adachi e Hayashi, 1986; Andrikopoulos et al., 1995; Gelse et al., 2003; Chanut-Delalande et al., 2004) (Figura 5).
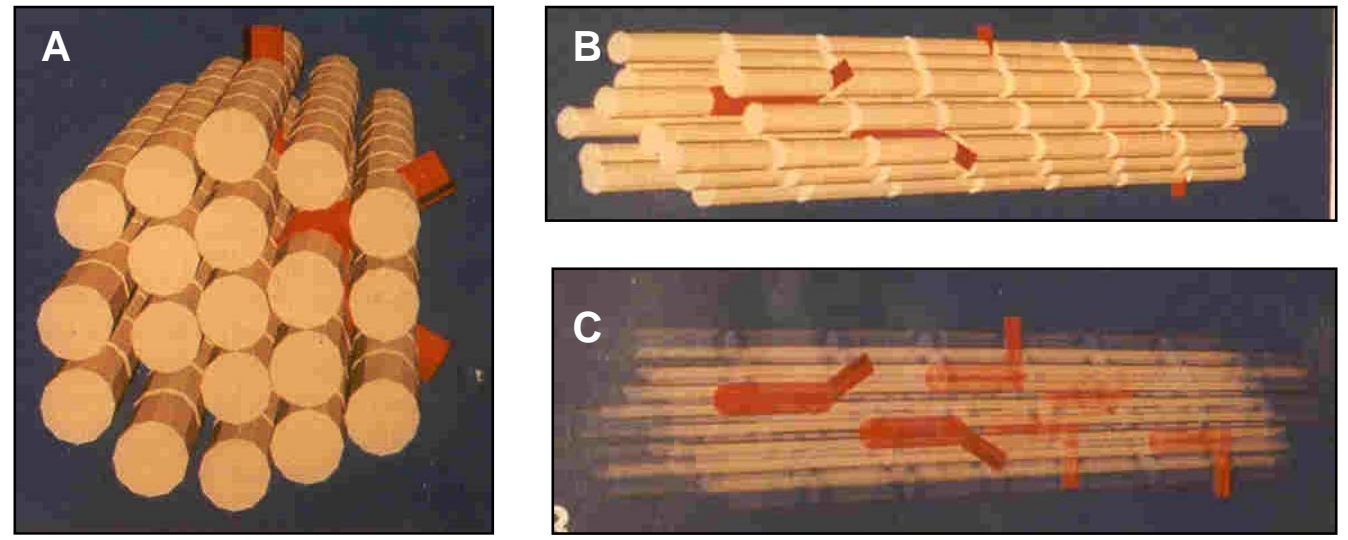

Figura 4 - Desenho ilustrativo representando a interação dos colágenos tipos I (amarelo) e tipo V (vermelho) nas fibrilas heterotípicas. A) Visão transversal da fibrila heterotípica, com o domínio glubular do colágeno tipo $\mathrm{V}$ (vermelho), voltado para o exterior da fibrila. B,C) Visão longitudinal da fibrila heterotípica, com a porção fibrilar (helicoidal) do colágeno tipo $\mathrm{V}$ (vermelho) no interior da fibrila e o domínio globular para a região externa. 


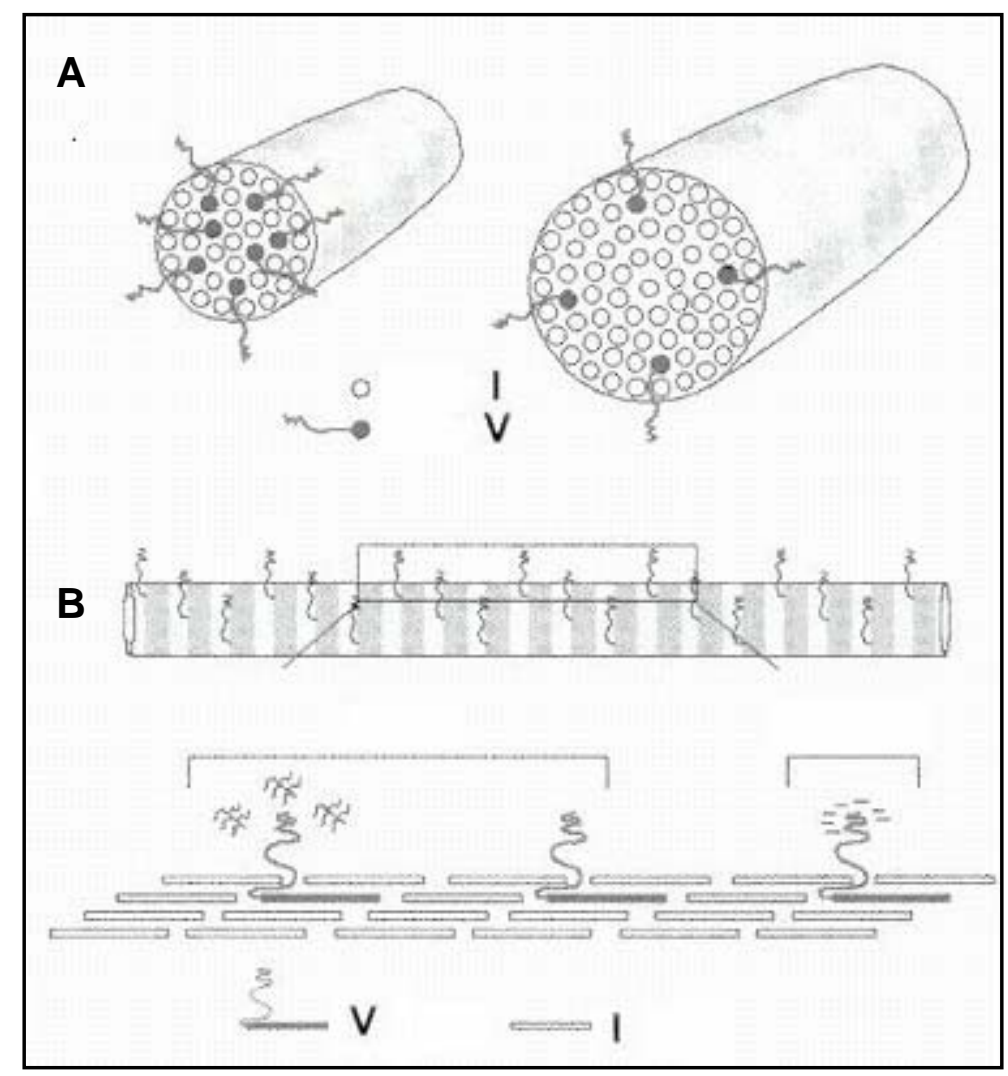

Figura 5 - Desenho esquemático da interação dos colágenos tipos I e $V$ nas fibrilas heterotípicas. A) Visão transversal mostrando fibrilas heterotípicas finas (à esquerda) e grossas (à direita). B) Visão longitudinal da fibrila heterotípica, mostrando que domínio globular do colágeno tipo $\mathrm{V}$, voltado para a região externa, impede fisicamente a agregação de novas moléculas de colágeno às fibrilas heterotípicas. O colágeno tipo $\mathrm{V}$ tem função na regulação do diâmetro das fibrilas heterotípicas, pois quando se encontra em maior proporção as fibrilas são mais finas e em menor proporção estas são mais grossas (A).

Existem várias isoformas de colágeno tipo $\mathrm{V}$, que diferem pela composição de suas cadeias. A forma mais abundante e amplamente distribuída é a heterotrímera, composta por duas cadeias $\alpha 1$ do tipo $\vee$ e uma cadeia $\alpha 2$ do tipo $\mathrm{V}\left[\alpha 1(\mathrm{~V})_{2} \alpha 2(\mathrm{~V})\right]$, sendo encontrada em vários tecidos, como pele, pulmão, rim, entre outros. Já a forma heterotrímera composta por três cadeias diferentes $[\alpha 1(V) \alpha 2(V) \alpha 3(V)]$ é encontrada principalmente em placenta e a forma homotrímera $\left[\alpha 1(V)_{3}\right]$ em tecido embriônico (Miller e Rhodes, 1982; Niyibizi et al., 1984; Mayne e Burgeson, 1993). 
Fibrilas muito finas de colágeno tipo $\mathrm{V}$ (5 a $10 \mathrm{~nm}$ de diâmetro) têm sido descritas na região próxima à membrana basal, estendendo-se até a matriz intersticial adjacente (Gay et al., 1981; Fitch et al., 1984; Modesti et al., 1984; Birk, 1986). Além disso, este envolve as células musculares dos vasos sanguíneos (Mayne e Burgeson, 1993). O colágeno tipo V é uma proteína preservada entre diferentes espécies de animais, conservando os telopeptídios $\mathrm{NH} 2$ e $\mathrm{COOH}$ terminais, os quais tornam a molécula mais imunogênica (Niyibizi et al., 1984).

Recentemente, foi demonstrado que o COL $\mathrm{V}$ pode ser um antígeno "self" potencial (Mares et al., 2000; Haque et al., 2002). Como citado acima, este colágeno interage com o tipo I, de forma que epítopos do colágeno $\mathrm{V}$ estão ocultos entre as fibrilas heterotípicas. Uma vez expostos, estes epítopos poderiam funcionar como um antígeno desconhecido e ativar o sistema imune.

Outro possível papel do $\mathrm{COL} \vee \mathrm{V}$ seria a indução de apoptose, participando na regulação da expressão de genes apoptóticos e de resposta ao estresse em linhagem de células neoplásicas no câncer de mama (PucciMinafra et al., 2000; Luparello et al., 2003; Luparello et al., 2005). Também é importante salientar que mutações nos genes do colágeno tipo V: COL5A1 e COL5A2 podem gerar anormalidades estruturais da córnea, tornando-as mais finas e frágeis (Segev et al., 2006). 


\section{1 - Auto-imunidade e colágeno tipo V}

Os aspectos imunogênicos da molécula de colágeno são, de maneira geral, invariáveis entre todas as suas isoformas fibrilares. Cada um dos domínios da molécula (helicoidais e telopeptídeos globulares) apresenta imunogenicidade espécie-específica, sendo capaz de desencadear uma resposta imune independente, justificando, de certa maneira, o fato de moléculas de procolágeno (forma precursora) e de colágeno denaturado (possui mais seqüências de aminoácidos expostas além dos domínios encontrados na molécula tradicional) apresentarem uma resposta mais difusa por parte do sistema imune.

Mares et al. em 2000, trabalhando com modelo de transplante de pulmão em murinos, mostraram que o colágeno tipo $\vee$ é alvo da resposta imune para aloantígenos. Verificaram que 0 tecido conjuntivo peribronquiolar, interstício alveolar e membrana basal dos capilares, nos quais o colágeno tipo $\vee$ está localizado, são os sítios de lesão patológica em resposta aos aloantígenos no modelo estudado. Nesta mesma linha de pesquisa, Haque et al., em 2002, encontraram células T específicas para o colágeno tipo $V$, que surgiram durante os episódios de rejeição do transplante de pulmão, e verificaram que estas células estavam envolvidas na patogênese da rejeição. Os autores sugeriram que, uma vez que o colágeno tipo $\mathrm{V}$ é uma molécula altamente conservada entre indivíduos e espécies, este seria um alvo na resposta de rejeição no pulmão. Ainda, demonstraram que respostas para um "auto"-antígeno, bem como 
aloimunidade, estão envolvidas na patogênese da rejeição do enxerto de pulmão. De acordo com os autores, o colágeno tipo $\mathrm{V}$ pode tornar-se um neoantígeno durante as respostas de rejeição, visto que este colágeno apresenta-se em menor proporção no pulmão e encontra-se oculto no interior do colágeno tipo I nas fibrilas heterotípicas, das regiões perivasculares e peribronquiolares. Durante o processo de rejeição e inflamação o tecido sofre ação das metaloproteinases, como a MMP-2 e MMP-3, e estas enzimas são capazes de clivar e expor o COL V, tornando-o imunogênico; deste modo, os diferentes peptídeos desta macromolécula poderiam induzir aloreatividade, desempenhando papel importante na rejeição do enxerto e remodelamento pulmonar (Haque et al., 2002).

Mais recentemente, Yoshida et al. (2006) estudaram a importância de células $\mathrm{T}$ específicas para $\mathrm{COL} \mathrm{V}$ na aloimunidade e auto-imunidade para colágeno tipo $\mathrm{V}$, usando um modelo de transplante de pulmão entre ratos isogênicos. Neste modelo ocorre uma lesão perivascular e peribronquiolar, devido à isquemia de perfusão resultante do procedimento cirúrgico; porém, este processo inflamatório começa a se resolver aos 3 dias de pósoperatório e aos 7 dias o isoenxerto está normal e se mantém até 16 meses de pós-transplante. Estes autores transferiram adotivamente células T específicas para colágeno tipo $\mathrm{V}$, para animais com isoenxerto de pulmão recente e bem cicatrizado e observaram rejeição (grau 2) do transplante de pulmão recente e rejeição ainda mais acentuada (grau 3) nos animais com 30 dias de pós-operatório. Além disso, observaram altos níveis de IL-17 e IL23, citocinas recentemente relacionadas com doenças auto-imunes. Com 
este experimento, sugeriram que em decorrência da lesão tecidual e conseqüente desorganização da matriz extracelular, ocorre exposição de epítopos de colágeno tipo $\mathrm{V}$, os quais se tornam importantes tanto na autoimunidade, como na aloimunidade.

Além destes achados, Yasufuku et al. em 2001 mostraram que a indução de tolerância oral ao colágeno tipo $\mathrm{V}$, nos recipientes de enxerto de pulmão, administrados anteriormente ao transplante, diminuía as respostas de rejeição. A análise imunológica, radiológica e histológica dos animais receptores de enxerto tratados oralmente com colágeno tipo $\mathrm{V}$, em relação ao controle demonstrou diminuição de células polimorfonucleares e linfócitos no fluido bronquioalveolar, menos infiltrados nos enxertos, preservação da anatomia do enxerto e redução da rejeição patológica. A administração oral de colágeno tipo $\mathrm{V}$ induziu aumento na produção de TGF- $\beta$, citocina com ação imunossupressora.

Estes autores, finalmente, mostraram que os receptores de enxerto, tolerados oralmente com $\mathrm{COL} \mathrm{V}$, exibiam diminuição das respostas de hipersensibilidade tardia para os aloantígenos do doador, o qual era neutralizado por TGF- $\beta$. Posteriormente, foram identificadas células T regulatórias ( $\mathrm{T}$ regs) $\left(\mathrm{CD} 4^{+} \mathrm{CD} 45 \mathrm{R} \mathrm{C}^{\text {higth }}\right)$, as quais mediam tolerância para colágeno tipo $\mathrm{V}$, em transplante de pulmão, no modelo experimental em ratos, que não expressam $\operatorname{Smad7}$ e, deste modo, são permissivas à sinalização mediada por TGF- $\beta$ (Mizobuchi et al., 2003). Os autores sugerem que, como o Smad7 é uma molécula protéica intracelular potente inibidora 
da sinalização para a produção de TGF- $\beta$, ele possa ser a chave na determinação de células que podem contribuir para a inflamação ou ativação da supressão imune, através de células T regs, com função regulatória.

Recentemente, células $\mathrm{T}$ específicas para colágeno tipo $\mathrm{V}$, que produziam IL-10 (citocina imunosupressora), foram detectadas no sangue periférico de pacientes, após o transplante de pulmão. Ainda, foi detectada menor proporção de células do subtipo Th1 (produtoras de IL-2 e INF- $\gamma$ ), específicas para colágeno tipo $\mathrm{V}$, as quais mediam inflamação e rejeição do transplante (Bharat, 2006). As células T, produtoras de IL-10, específicas para COL V, suprimiam a proliferação e expansão das células Th1, de um modo dependente de IL-10. Porém o desenvolvimento destas células, produtoras de IL-10, foi dependente da presença de células $T$ regs (CD4 $\left.{ }^{+} \mathrm{CD} 25\right)$. Por outro lado, durante a rejeição crônica do transplante de pulmão foi encontrado um significante declínio de células $\mathrm{T}$, produtoras de IL-10, com concomitante expansão das células Th1 específicas para colágeno tipo $\mathrm{V}$ (Bharat, 2006). Isto demonstra a importância de células $T$ regs $\left(C D 4^{+} C D 25\right)$ constitutivas na modulação da auto-imunidade celular para COL V, após transplante de pulmão em humanos.

\section{4 - Tolerância imunológica}

Tolerância imunológica é definida como um mecanismo pelo qual o sistema imunológico evita a autoreatividade patológica contra antígenos próprios e, deste modo, previne as doenças auto-imunes. Durante a maturação do sistema imune ocorre uma seleção negativa nos órgãos 
linfóides primários ou gerativos, como o timo para linfócitos T e medula óssea para linfócitos $B$, no qual os linfócitos imaturos autorreativos são deletados, por um processo de tolerância central. Ainda, em condições normais, linfócitos maduros com baixa afinidade para autoantígenos, os quais escapam do processo de tolerância central e circulam na periferia ou estão presentes nos órgãos, permanecem não reativos, por um processo de tolerância periférica. O repertório de linfócitos maduros contém células capazes de reconhecer autoantígenos, porém as condições de exposição dos antígenos e a regulação da resposta dos linfócitos são críticos para determinar a autotolerância ou a autorreatividade (Abbas et al., 1997).

Os principais mecanismos de tolerância de clones de linfócitos específicos para antígenos próprios são: a anergia clonal, a deleção clonal e a indução de células $\mathrm{T}$ regs. Na anergia clonal ou inativação funcional, as células reconhecem o antígeno próprio, entretanto, não ocorrem os sinais co-estimulatórios. Normalmente, as células apresentadoras de antígeno (CAA) que estão em um estado de "repouso" nos tecidos expressam baixos níveis de moléculas co-estimuladoras e citocinas, que estimulam a resposta de células T. Deste modo, se tais CAA apresentam antígenos próprios para as células T específicas, estas podem tornar-se anérgicas (não responsivas) (Figura 6). As lesões teciduais ou processos inflamatórios podem ativar CAA residentes, levando ao aumento de expressão de moléculas coestimulatórias e citocinas e à perda da autotolerância, culminando em reações auto-imunes contra antígenos do tecido (Abbas et al., 1997). 
No mecanismo de deleção clonal, antígenos próprios, que são apresentados em altas concentrações, podem repetidamente estimular as células T específicas, levando-as à morte celular programada ou apoptose (Figura 6). A tolerância central é principalmente devida à deleção clonal, enquanto que, ambos os mecanismos, contribuem para a tolerância periférica (Abbas et al., 1997). Por fim, alguns linfócitos T reativos para antígenos próprios podem não se tornar anérgicos ou ser deletados, porém sua atividade pode ser suprimida pela ação de citocinas imunosupressivas, tais como IL-10 e TGF- $\beta$ produzidas por células T regs (Figura 6).

As $T$ regs são populações de células $T$ específicas que têm propriedades supressivas/regulatórias e controlam a resposta imune autoreativa (Jonuleit e Schimitt, 2003). Entre as células $\mathrm{T}$ regs $\mathrm{CD}^{+}$, basicamente duas subclasses se distinguem, pelos seus mecanismos supressores: as $\mathrm{T}$ regs constitutivas $\mathrm{CD} 4^{+} \mathrm{CD} 25^{+}$, que exercem sua função supressora pelo contato células a células, através de moléculas ligadas à membrana, de natureza ainda não bem conhecida (Jonuleit e Schimitt, 2003), e as T regs induzidas, as quais executam sua função regulatória de um modo independente do contato célula a célula, através da produção de citocinas imunossupressivas (IL-10 e TGF- $\beta$ ) (Jonuleit e Schimitt, 2003). Existem alguns tipos de células $\mathrm{T}$ regs induzidas, tais como: as células regulatórias tipo $1(\operatorname{Tr} 1)$, as quais produzem altos níveis de IL-10, além de TGF- $\beta$; as células Th3, caracterizadas pela produção de altos níveis de TGF$\beta$ e variáveis quantidades de IL-4 e IL-10; além das recentemente descritas 
$\mathrm{CD}^{+}{ }^{+}$D28 ${ }^{-} \mathrm{FOXP3}^{+}$e células $\mathrm{CD}^{+}{ }^{+} \mathrm{AP}^{+}$(Jonuleit e Schimitt, 2003; Taylor et al., 2006; Faria e Weiner, 2006).

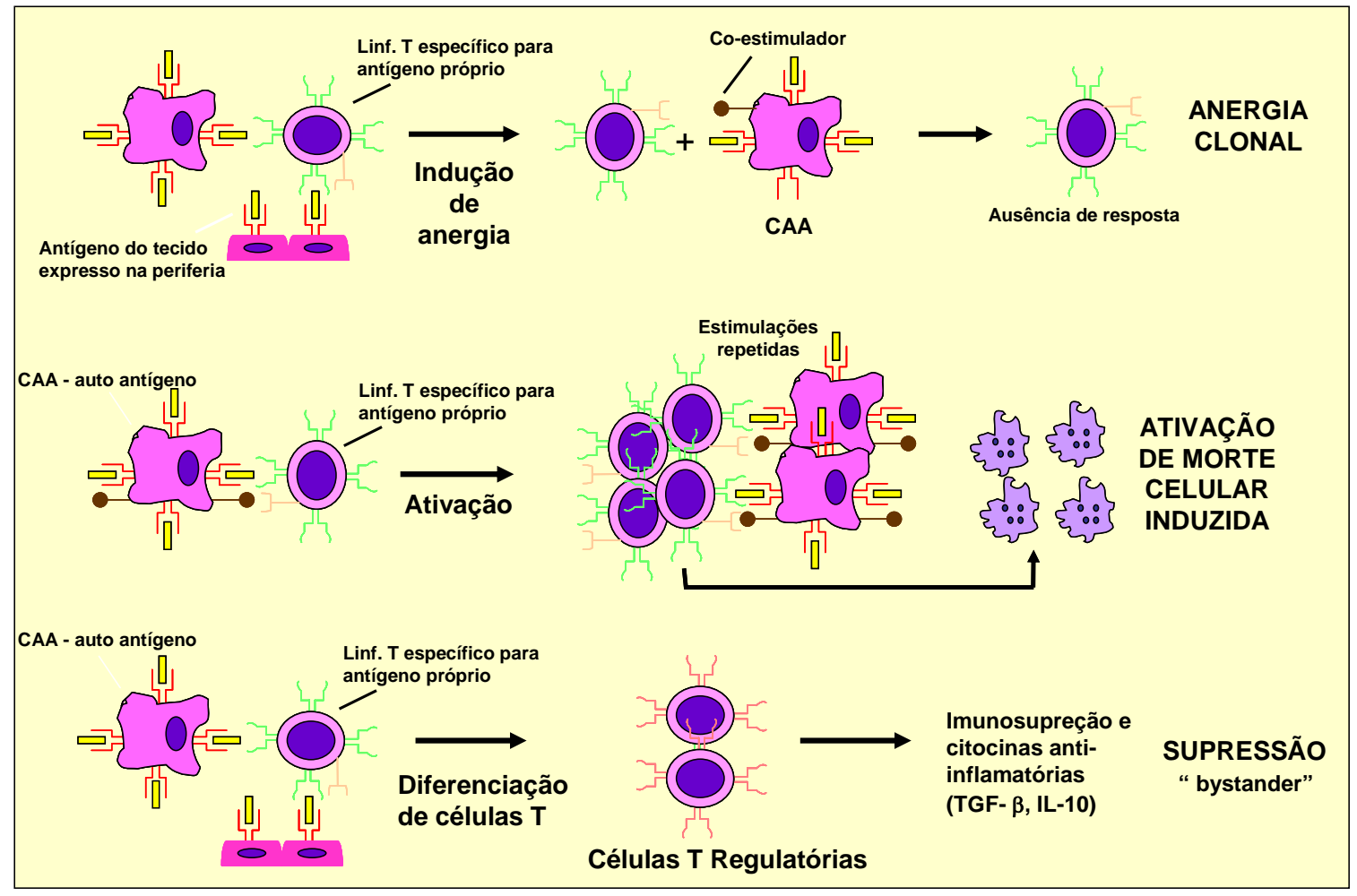

Figura 6 - Diagrama esquemático mostrando os mecanismos de tolerância imunológica. Anergia clonal, ativação de morte celular induzida (deleção clonal) e supressão pela ativação de células $T$ regulatórias. CAA, célula apresentadora de antígeno; Co-estimulador, molécula co-estimulatória. (Abbas, 1998)

\section{1 - Tolerância nas mucosas}

A superfície das mucosas contém o maior e mais complexo sistema imunológico do organismo, porém pouco conhecido, que é o tecido linfóide associado às mucosas (MALT, "mucosal-associated lymphoid tissue"). Este protege o organismo contra antígenos microbianos patológicos ou de origem tumoral, mas também gera tolerância para antígenos inócuos ou micróbios comensais. O MALT congrega os tecidos linfóides associados às mucosas 
intestinais (GALT, "gut-associated lymphoid tissue"), naso-faríngeas (NALT, "nasal-associated lymphoid tissue"), da mucosa brônquica (BALT, "bronchialassociated lymphoid tissue") e das mucosas de outros tecidos linfóides associados com os sistemas lacrimal, mamário, glandular, gênito-urinário, cutâneo, e outros (Bueno Pacheco-Silva, 1999).

Aproximadamente $50 \%$ a $60 \%$ da imunidade total do organismo humano localiza-se subjacente às superfícies mucosas das vias respiratórias altas e baixas, do intestino delgado e do colo, responsáveis por $70 \%$ a $80 \%$ da produção de anticorpos (basicamente a imunoglobulina A de secreção IgAs, principal imunoglobulina encontrada em todas as secreções orgânicas externas) (Bueno Pacheco-Silva, 1999).

A tolerância nas mucosas é um componente funcional essencial, que previne eficientemente a excessiva estimulação do sistema imunológico, como um todo, contra antígenos alimentares inertes e alérgenos ambientais. Nesse âmbito, recentemente a tolerância nas mucosas tem despertado o interesse de pesquisadores em vários campos, como na auto-imunidade, transplantes de órgãos e alergia, uma vez que a administração prévia de antígenos específicos, importantes em processos patológicos, pela via das mucosas, leva à indução de ausência de resposta imunológica sistêmica para estes antígenos (Mestecky et al., 2005).

A indução de tolerância pela administração de antígenos, pela via das mucosas, depende de algumas variáveis, incluindo a espécie, genética, idade, dose, forma (solúvel versus partículas, vivo versus inativado) e a via da administração do antígeno. As principais vias de administração de 
antígenos pelas mucosas, utilizadas experimentalmente e na clínica médica para gerar tolerância periférica, com o intuito de prevenir e/ou tratar doenças auto-imunes e alérgicas ou evitar rejeição de transplantes, são a oral e nasal.

\subsubsection{Tolerância oral}

A tolerância oral é definida como supressão da resposta imunológica celular e/ou humoral a um antígeno pela prévia administração deste pela via oral. O objetivo deste tipo de tolerância é o de suprimir a reatividade imune específica sem afetar o sistema imunológico como um todo, através da deleção ou inativação de clones de células T direcionados a estes antígenos específicos. Os mecanismos envolvidos na indução de tolerância oral são atualmente os melhor estudados, sendo um complexo processo que resulta na supressão de algumas respostas imunes e indução de outras (Weiner, 2001).

Os antígenos administrados oralmente encontram o GALT, o qual consiste de nódulos linfáticos bem desenvolvidos chamados de placas de Peyer, vilosidades, contendo células epiteliais, linfócitos intra-epiteliais e linfócitos espalhados através da lâmina própria (figura 7 A). Existem também várias CAA, como macrófagos, células $B$, células epiteliais e células dendríticas, sendo estas últimas as principais CAA no intestino (Weiner, 2001). Uma vez que os antígenos entram em contato com a superfície do intestino, estes podem ser englobados por diferentes células, como pelas 
células $\mathrm{M}$ das placas de Peyer, pelas células dendríticas ou pelas células epiteliais (Figura 7 B). Os antígenos particulados são preferencialmente absorvidos pelas células $\mathrm{M}$, das placas de Peyer, e antígenos solúveis pelo epitélio das vilosidades, e, dependendo das suas características, pode resultar em diferentes respostas (Faria e Weiner, 1999).
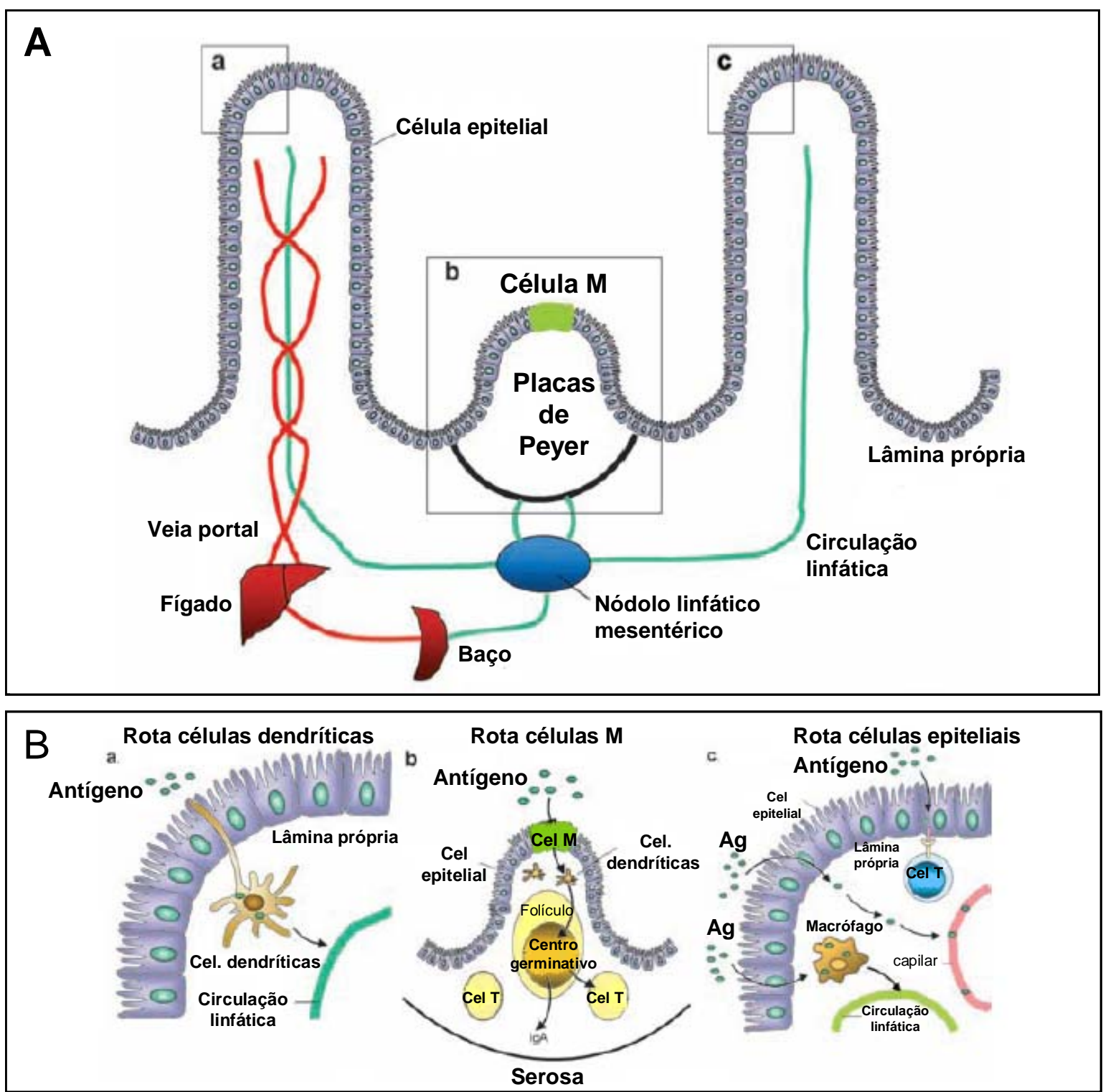

Figura 7 - Tecido linfóide associado ao intestino (GALT). A) Vilosidades, contendo células epiteliais, placas de Peyer com células $M$ e lâmina própria. B) Sítios de percepção do antígeno no GALT. a. O antígeno pode ser englobado pelas células dendríticas, que se estendem até o lúmen. b. As partículas de antígeno podem entrar pelas células $M$, nas placas de Peyer e posteriormente ser englobadas pelas células dendríticas na região subepitelial e então passar para a base do folículo, onde ocorre concomitante produção de $\lg$ A pelas células B. c. Antígenos solúveis poderiam atravessar através do epitélio transcelular ou paracelular e então poderiam encontrar células T ou macrófagos na lâmina própria ou poderiam alcançar a circulação. (Bellanti, 2006). 
A apresentação de antígenos resulta na indução de várias células que trafegam para o sistema circulatório, via nódulos linfáticos mesentéricos e ducto torácico, as quais migram de volta para a lâmina própria e para outros sítios da mucosa ou para regiões de não mucosa (Faria e Weiner, 1999) (figura 7).

Existem dois mecanismos efetores envolvidos na tolerância oral: a indução de anergia ou deleção clonal e a indução de células T regs, as quais mediam a supressão ativa (Faria e Weiner, 1999; Weiner, 2001; Faria e Weiner, 2005). O fator primário que determina qual forma de tolerância periférica se desenvolve após a administração oral de antígenos é a dose de antígeno administrada. A administração oral de baixas doses de antígeno induz a ativação de células $\mathrm{T}$ regs específicas para o antígeno, seguindo a apresentação deste pelas CAA nas placas de Peyer. As células $\mathrm{T}$ regs geradas no intestino são principalmente dos subtipos: Th2, que secreta IL-4 e IL-10, e Th3, que secreta grande quantidade de TGF- $\beta$, além de células Tr1, que secretam IL-10, células $\mathrm{T}$ regs $\mathrm{CD} 4^{+} \mathrm{CD} 25^{+}$e células $\mathrm{CD} 4^{+} \mathrm{LAP}^{+}$ (Weiner, 2001; Jonuleit e Schmitt, 2003; Taylor et al., 2006; Faria e Weiner, 2006) (Figura 8 e Figura 9).

Uma vez ativadas pelos antígenos específicos as células $\mathrm{T}$ regs migram para os órgãos linfóides e suprimem a resposta imune pela inibição da geração das células efetoras, estas também migram para os órgãos alvo, suprimindo a doença pela liberação de citocinas não específicas para o antígeno (Faria e Weiner, 2005). Este fenômeno é referido como uma 
supressão "bystander" (Miller et al., 1991) (Figura 6). Vários autores sugerem que a indução de um determinado subtipo de células $\mathrm{T}$ regs depende do microambiente de citocinas presente na mucosa, onde ocorre a tolerância periférica. Assim, como o intestino é extremamente rico em TGF$\beta$, preferencialmente as células Th3 são induzidas por tolerância ora I (Weiner, 2001).

Por outro lado, a administração oral de grandes quantidades de antígeno resulta na ausência de resposta de células Th1 e Th2 por anergia ou deleção clonal (Figura 8).



Figura 8 - Os diferentes mecanismos de tolerância oral são determinados pela dose de antígeno administrada. GALT, tecido linfóide associado ao intestino; IL, interleucinas; Th, linfócito T auxiliar. (Faria e Wiener, 1999) 
Embora estas formas de tolerância sejam distintas, elas não são mutuamente exclusivas e podem ocorrer simultaneamente. Assim, a utilização de tolerância oral para o tratamento de doenças auto-imunes é criticamente dependente de qual dos dois mecanismos é desencadeado.

Alguns autores demonstram que a ligação entre os eventos de deleção clonal, após a administração oral de grandes quantidades de antígeno e a indução de células T regs, está relacionada com apoptose das células. A fagocitose das células apoptóticas por macrófagos resulta na diminuição da produção de citocinas pró-inflamatórias e indução de produção de TGF- $\beta$ (Freire-de-Lima et al., 2000). Além disso, as próprias células apoptóticas podem, também, liberar TGF- $\beta$ tanto na forma latente, como bio-ativa. Deste modo, estes dois eventos relacionados a apoptose na mucosa do intestino podem contribuir para a geração de citocinas imunossupressivas e resultar na indução de células T regs, visto que o TGF$\beta$ age como fator de crescimento para células Th3 e células $\mathrm{CD}^{+} \mathrm{CD}^{+} 5^{+}$FoxP3 $^{+}$(Paul e Seder, 1994; Faria e Wiener, 1999; Weiner, 2001; Sakaguchi, 2004) (Figura 9).

Por outro lado, a anergia clonal parece ser a base da tolerância periférica para muitos auto-antígenos, e sua presença em tolerância oral foi primeiro sugerida por experimentos, nos quais a tolerância pode ser revertida in vitro por IL-2 exógeno (Whitacre et al., 1991). Vários trabalhos demonstram que a dicotomia entre anergia e supressão ativa pode não ser completa, visto que têm sido descritas células T regs anérgicas (Takahashi 
et al., 1998; Tsuji et al., 2003) (Figura 9). Atualmente, é bem estabelecido que células anérgicas possam reter outras funções, tais como produção de citocinas, incluindo IL-4 e IL-10 (Lanoue et al., 1997; Bouer et al., 1998). Além do mais, em um grande número de circunstâncias, células CD4 ${ }^{+}$ anérgicas parecem atuar como células supressoras in vivo e in vitro (Takahashi et al., 1998; Hirahara et al., 1995; Taams et al., 1998; Lombardi et al., 1997; Hoyne e Lamb, 1997) (Figura 9).

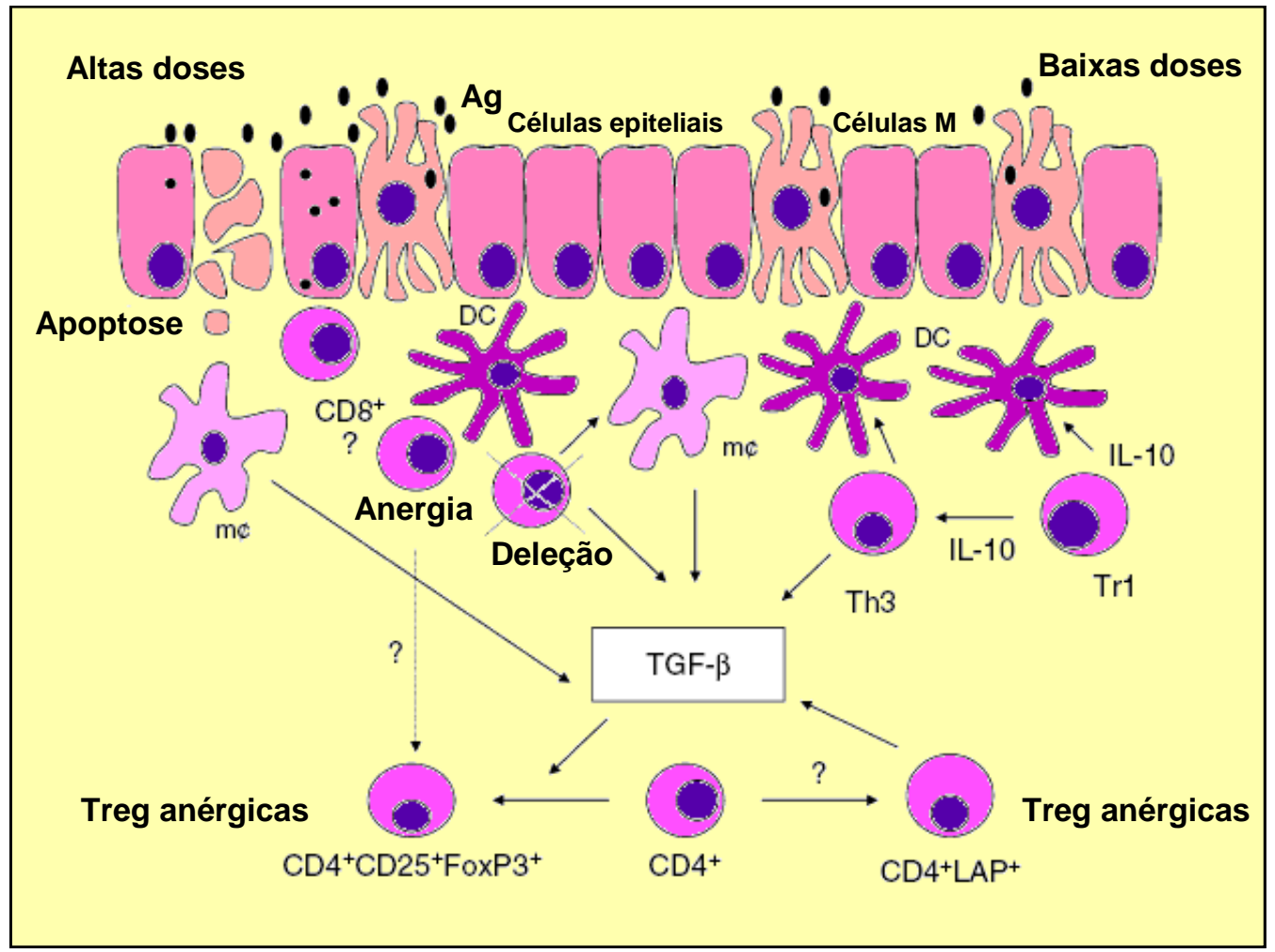

Figura 9 - Mecanismos de indução de tolerância oral e TGF- $\beta$. Baixas doses de antígeno desencadeiam supressão ativa. Várias células regulatórias estão envolvidas na tolerância oral e imunoregulação no intestino: Th3, Tr1, células T $\mathrm{CD}^{+} \mathrm{CD}^{2} 5^{+}$e $\mathrm{CD} 4^{+} \mathrm{LAP}^{+}$. As células Th3 secretam altas quantidades de TGF- $\beta$, Tr1 secretam IL-10, o qual aumenta a produção de TGF- $\beta$ pelas células Th3. Por outro lado, o TGF- $\beta$ é um fator crítico para a expressão de FoxP3 e o desenvolvimento de células $\mathrm{T} \mathrm{CD} 4^{+} \mathrm{CD} 25^{+}$. As células $\mathrm{CD} 4^{+} \mathrm{LAP}^{+}$também tem uma forma de TGF- $\beta$ na membrana e sua função regulatória é dependente de TGF- $\beta$. Altas doses de antígeno pela via oral desencadeiam deleção ou anergia de células $\mathrm{T}$ específicas. A apoptose de células $\mathrm{T}$ e células epiteliais no intestino levam à fagocitose destas células pelos macrófagos, com conseqüente produção de TGF- $\beta$ pelos fagócitos. A relação entre células anérgicas que são desencadeadas após altas doses de antígeno e células regulatórias anérgicas não é bem conhecida, mas a anergia é bem documentada em vários tipos de células $\mathrm{T}$ supressoras. (Faria e Weiner, 2005). 


\subsubsection{Tolerância nasal}

A tolerância nasal é a supressão da resposta imunológica celular e/ou humoral a um antígeno pela prévia administração deste pela via nasal. A administração de antígenos pela mucosa respiratória tem vantagens, visto que estes são menos degradados e, portanto, uma quantidade significativamente menor de antígeno pode ter a mesma, ou mais eficácia, em relação à tolerância oral (Higuchi et al., 2000; Bárdos et al. 2002).

O trato respiratório, continuamente exposto a uma variedade de antígenos, é constituído pelo tecido linfóide associado aos brônquios (BALT), o qual inclui agregados linfóides ao longo do trato bronquial. Além disso, um tecido linfóide bem desenvolvido circunda a cavidade nasal, com seu próprio meio ambiente distinto; este corresponde ao tecido linfóide associado ao nariz (NALT) (Faria e Weiner, 1999). A mucosa brônquica se assemelha à intestinal em vários aspectos; apresenta células dendríticas, que são apresentadoras de antígenos, além de células T, capazes de iniciar uma resposta imune.

Alguns autores têm demonstrado que a tolerância imunológica induzida pela rota nasal é determinada pelas características dos nódulos linfáticos que drenam do nariz (Wolvers et al., 1999). Foi demonstrado que a administração de antígenos pela rota nasal leva à ativação de nódulos linfáticos cervicais na região do pescoço (Hoyne et al., 1996). Posteriormente, Wolvers et al. (1999) demonstraram que em camundongos, independentemente do antígeno ou sítio de imunização, a indução de 
tolerância por via nasal é estritamente dependente de nódulos linfáticos cervicais ou jugular internos. Além disso, esses nódulos linfáticos contêm características intrínsecas cruciais, visto que a substituição destes por nódulos de outros sítios periféricos não induz tolerância nasal (Wolvers et al., 1999). Estes autores demonstraram que as vênulas endoteliais altas da mucosa cervical e dos nódulos linfáticos cervicais e jugular internos da mucosa nasal expressam MadCAM-1, moléculas de adesão denominadas adresinas, importantes no deslocamento de linfócitos. Estas moléculas de adesão estão ausentes em outros nódulos linfáticos periféricos. Outra característica interessante é o fato de que após a administração nasal de antígenos, um número substancial de células apresentadoras de antígenos (CAA) expondo epítopos foi localizado no baço. Com a remoção dos nódulos linfáticos do nariz estas células não são mais encontradas neste órgão (Wolvers et al., 1999). Isto demonstra que o ambiente local dos nódulos linfáticos cervicais é essencial para a indução de tolerância nasal.

Os mecanismos de indução de tolerância nasal não estão bem estabelecidos. Evidências indicam que similarmente à tolerância oral, os mecanismos de indução de tolerância nasal dependem da dose de antígeno administrada, uma vez que altas doses de antígeno podem resultar na indução de deleção ou anergia clonal (Bitar e Whitacre, 1988; Whitacre et al., 1991), enquanto que baixas doses de antígeno solúvel podem levar à tolerância periférica por um processo de ativação de supressão ativa, por células T regs (Líder et al., 1989; Miller et al., 1991; Miller et al., 1992; Miller et al., 1993). 
Vários estudos indicam que a tolerância nasal induz preferencialmente mecanismos regulatórios, capazes de suprimir as reações de hipersensibilidade tardia, decorrente de células Th1, além de IgE mediada por células Th2 (Van Halteren et al., 1997; Wolvers et al., 1997). Recentemente foi demonstrado que, em experimentos de indução de tolerância nasal com ovalbumina (OVA) em camundongos transgênicos, foram encontradas células $\mathrm{T} \mathrm{CD}^{+}$, com função regulatória, as quais apresentam $C D 25^{+}$ou CD25; , e podiam ser isoladas dos nódulos linfáticos cefálicos três dias após a aplicação nasal de OVA; e ainda, podiam bloquear as respostas de hipersensibilidade tardia por transferência adotiva (Unger et al., 2003). Entretanto, somente as células $C D 4^{+} C D 25^{-}$, induzidas por tolerância nasal com OVA, eram específicas para o antígeno (Unger et al., 2003).

Embora a tolerância nasal esteja sendo muito utilizada e tenha mostrado grande eficácia na prevenção e tratamento de doenças autoimunes em vários modelos experimentais, mais estudos são necessários para determinar especificamente a base celular e molecular das células $\mathrm{T}$ regs e os mecanismos envolvidos na tolerância nasal.

\subsection{Tratamento de doenças auto-imunes e tolerância}

Células autoreativas, tais como as que reagem com antígenos do cérebro, tiroglobulina, albumina sérica, colágeno e outros autoantígenos, não são, de fato, totalmente deletadas e estão presentes em todos os indivíduos 
(Zhang et al., 1993). Estas não somente permanecem não ativas em condições normais, mas podem ter uma função importante na manutenção da homeostase do tecido e podem ser diferencialmente focadas dependendo do tecido ou autoantígeno (Cohen e Young, 1991). Porém a quebra da tolerância imunológica, pelas mais diversas razões, pode desencadear as doenças auto-imunes.

Vários estudos em modelos experimentais de doenças auto-imunes, incluindo encefalomielite, uveíte, diabetes, miastenia gravis, artrite e outras têm demonstrado um grande potencial para a prevenção e tratamento de doenças auto-imunes, através da restauração da tolerância imune para antígenos específicos, relevantes nestas doenças (Tabela 2) (Faria e Weiner, 1999).

A maioria dos experimentos relacionados à indução de tolerância nas mucosas é feita em roedores, como ratos e camundongos, usando antígenos clássicos, tais como ovalbumina (OVA), albumina bovina (BSA) ou gamaglobulina bovina (BGG), bem como antígenos relevantes em modelos animais de doenças auto-imunes (Tabela 2). Neste último caso, experimentos extensivos feitos em animais demonstram, convincentemente, que exposição oral ou nasal de antígenos, tais como proteína básica da mielina (MBP) ou colágeno tipo II e outros, induzem um estado de não responsividade sistêmica, após subseqüente imunização sistêmica (Mowat e Weiner, 1999; Czerkinsk et al., 1999). 
Tabela 2 - Modelos experimentais de doenças suprimidas por tolerância oral (Faria e Weiner, 2005)

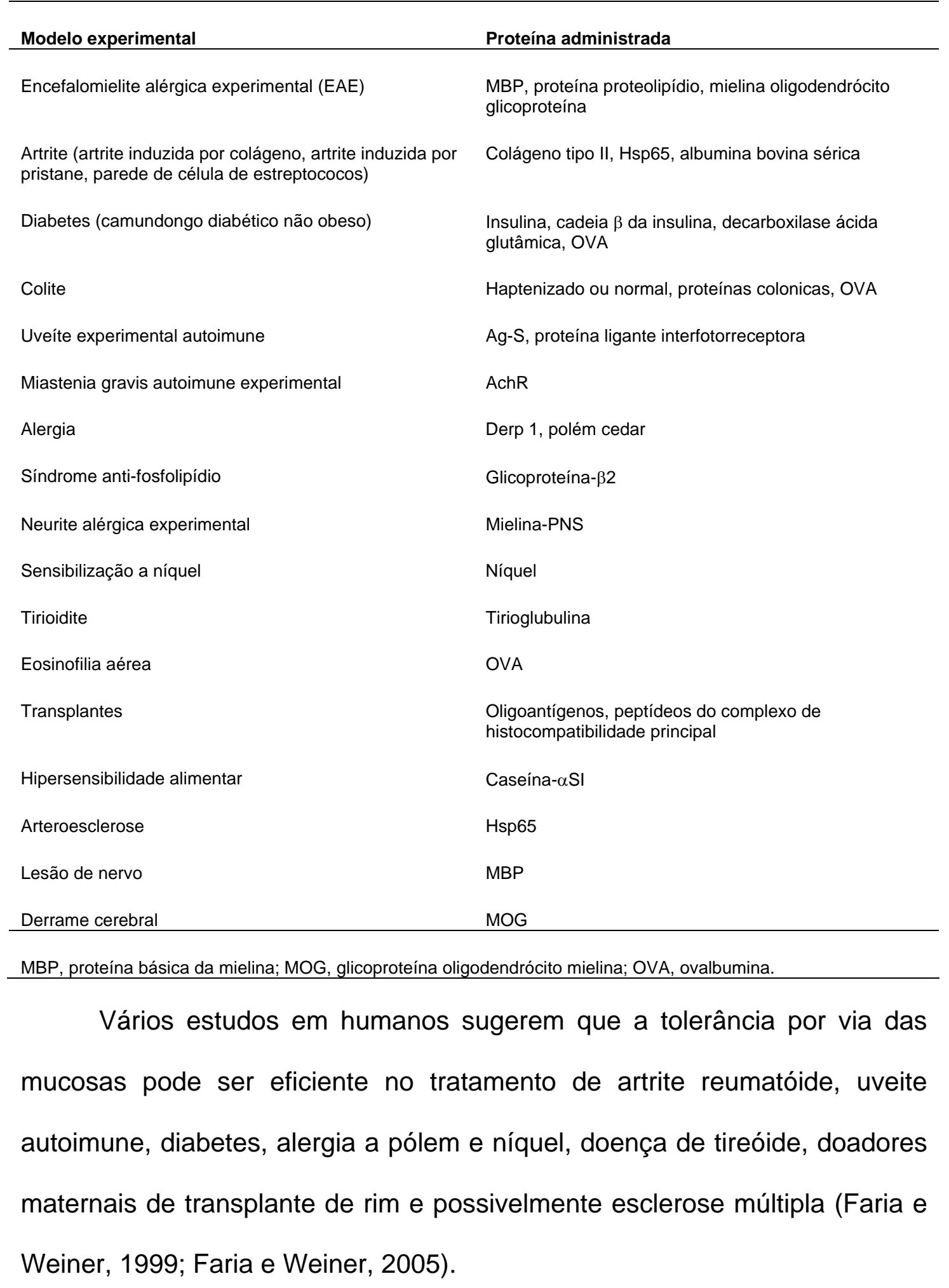


A utilização do colágeno para indução de tolerância oral ou nasal na prevenção e tratamento de artrite reumatóide experimental e em humanos é clássica. Experimentalmente, a artrite reumatóide pode ser induzida de vários modos, incluindo: artrite induzida por colágeno, artrite induzida por adjuvante, artrite induzida por antígeno, artrite induzida por pristane, artrite induzida por silicone e artrite induzida por parede de células de estreptococos. Assim, a administração oral ou nasal de colágeno tipo II ou tipo IX e peptídeos de colágeno e outros antígenos, como o Hsp60, mostraram ser efetivas na supressão de vários destes modelos de artrite (Thompson et al., 1993; Yoshino, 1995; Khare et al., 1995; Yoshino, 1998; Chen et al., 1998 ; Thorbecke et al., 1999; Thorbecke et al., 1999; Garcia et al., 1999, Faria e Weiner, 1999; Prakken et al., 2002; Bárdos et al., 2002). Além disso, recentemente foi demonstrada a indução de células $T$ regs $\left(C D 4^{+} C D 25^{+}\right)$que produzem IL-10, pela administração oral de colágeno tipo II em artrite experimental em camundongos induzida por colágeno (Min et al., 2003).

Embora existam poucos relatos em relação à indução de tolerância no tratamento de ES, a tolerância imune para o colágeno tipo I já foi testada em pacientes com ES, através da administração oral de colágeno tipo I de bovinos, num protocolo com duração de doze meses (Mckown et al., 2000). Os autores verificaram que a tolerância oral ao colágeno tipo I em pacientes com esclerodermia difusa ou limitada induz à redução da reatividade das células T para colágeno tipo I humano e parece ser bem tolerado, além de não piorar o quadro do paciente (Mckown et al., 2000). 


\section{II - OBJETIVOS}

Baseados nos estudos recentes da patogênese da esclerodermia que sugerem a importância da resposta T celular, principalmente Th2, para um possível antígeno, ainda desconhecido; e considerando-se que a imunização de coelhos sadios com colágeno tipo $\mathrm{V}$, desencadeia uma série de alterações histológicas e sorológicas, muito semelhantes à esclerodermia em humanos, propomos induzir a tolerância nasal com emprego deste colágeno, ministrado 150 dias após a primeira imunização. Optamos por este desenho de pesquisa, na tentativa de reproduzir o possível uso terapêutico da tolerância imunológica nos pacientes com esclerodermia, ou seja, em animais com complicações sistêmicas estabelecidas como ocorre em humanos.

Assim, temos como objetivo verificar se os animais com esclerodermia experimental apresentam melhoras quanto aos aspectos morfológicos e imunológicos, após tratamento intranasal com colágeno tipo $V$, através da:

- Avaliação morfológica e morfométrica da pele dos coelhos, após indução de tolerância nasal com colágeno tipo V; 
- Avaliação do remodelamento dos colágenos I, III e $\mathrm{V}$ na pele dos coelhos, após indução de tolerância nasal com colágeno tipo $\mathrm{V}$;

- Avaliação da expressão de TGF- $\beta$ e PDGF, além de apoptose de células, após indução de tolerância nasal com colágeno tipo $\mathrm{V}$;

- Avaliação da produção de auto-anticorpos (anti-col I, III, IV e ANA), após indução de tolerância nasal com colágeno tipo V. 


\section{1- Modelo experimental de ES por imunização com COL V}

Coelhas da linhagem Nova Zelândia $(\mathrm{N}=12)$ foram imunizadas com

COL V por via sub-cutânea, injetando-se $1 \mathrm{mg} \mathrm{COL} \mathrm{V}$, isolado de placenta humana, extraído por precipitação com cloreto de sódio (Miller e Rhodes, 1982), diluído em $1 \mathrm{ml}$ de ácido acético $10 \mathrm{mM}$ e adicionado em igual volume de adjuvante completo de Freund (Sigma Chemical Co.; St. Luois, Missouri, USA). Quatro semanas após, as coelhas receberam uma dose idêntica de COL V e dois reforços de imunização pela via intramuscular, separados em intervalo de 15 dias (1mg COL V mais $1 \mathrm{ml}$ adjuvante incompleto de Freund). O grupo controle $(\mathrm{N}=6)$ foi inoculado com adjuvante Freund completo ou incompleto diluído em $10 \mathrm{mM}$ de ácido acético, do mesmo modo que foi utilizado para a imunização com COL V. Animais de ambos os grupos apresentavam a mesma idade com peso aproximado de $2500 \mathrm{~g}$. 


\section{2 - Indução de tolerância nasal com colágeno tipo V}

A tolerância nasal foi induzida em um grupo $(n=6)$ de animais imunizados com colágeno tipo $\mathrm{V}$ (grupo TOL-COL $\mathrm{V}$ ), através de administração nasal de doses diárias de $25 \mu \mathrm{g}$ de colágeno tipo $\mathrm{V}$ diluído em $25 \mu$ l de ácido acético $10 \mathrm{mM}$. A indução de tolerância nasal foi iniciada 150 dias após a primeira imunização, estendendo-se durante 60 dias. No final deste período, os animais foram sacrificados. O outro grupo de seis animais imunizados (grupo imunizado) não foi submetido à indução de tolerância com colágeno tipo $\mathrm{V}$, sendo sacrificado em 210 dias. O grupo controle $(n=6)$ inoculado com adjuvante de Freund completo e incompleto (grupo controle) foi também submetido à indução de tolerância nasal com colágeno tipo $\mathrm{V}$

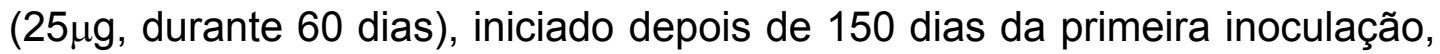
sendo sacrificado com 210 dias, como os outros grupos.

\section{3 - Biópsias de pele}

Após anestesia, cada animal foi submetido a uma série de biópsias seqüenciais realizadas em regiões distintas do dorso. Um total de três biópsias foram feitas em todos os animais a 0 (antes da imunização com colágeno tipo V), 150 (antes da indução de tolerância nasal) e 210 dias após o início das imunizações. As amostras coletadas foram imersas em formol a $10 \%$ por 24 horas, embebidas em parafina, cortadas numa espessura de 3$4 \mu \mathrm{m}$ e coradas com hematoxilina e eosina (H\&E) e tricrômico de Masson para análise morfológica. Após 210 dias todos os animais foram anestesiados com $2 \%$ de (2,6-xilidino) 5,6-dihidro-4H 1,3-tiazina $1 \mathrm{M}$ 
(Rompum, Bayer do Brasil S. A.) e eutanasiados por doses letais de Ketanina (Ketalar, Park-Davis) 1 M. Os outros órgão, tais como pulmão, coração, rim, esôfago, sinóvia, aorta, cartilagem articular foram coletadas para análises morfológicas futuras.

\section{4 - Análise morfométrica}

As fibras de colágeno foram avaliadas em biópsias de pele para quantificação de colágeno total realizadas em 0, 150 e 210 dias após a primeira imunização. Para a análise de colágeno, cortes de pele (3 $\mu \mathrm{m})$ foram corados com $0,2 \%$ de solução de Sirius red (Direct Red 80, C. I. 35780, Aldrich, Milwaukee, WI 53233, USA) dissolvido em solução aquosa saturada de ácido pícrico (Shapiro et al., 1991). A intensidade da birrefringência nas três camadas da pele (derme papilar, derme reticular e derme profunda) foi determinada por densidade óptica em um sistema de análise de imagem em 10 campos diferentes, selecionados aleatoriamente. O sistema utilizado consiste de uma câmara CCD Sony DXC-101 acoplada a um microscópio Zeiss Axioplan, de onde as imagens foram enviadas para um monitor (Sony Trinitron). Através de um sistema de digitalização (Oculus TCX; Coreco Inc., St. Laurent, Quebec, Canadá) inserido em um computador (Pentium $133 \mathrm{Mhz}$ ), as imagens foram processadas pelo software (Imagen Pro-Plus). Um total de 10 campos por caso foram analisados em um aumento de 100x. 


\section{5 - Imunofluorescência para os colágenos tipos I, III e V, TGF- $\beta$ e PDGF}

Para a imunodetecção dos colágenos tipos I, III e V, as amostras de peles de animais foram embebidas em parafina e fragmentos montados em lâminas com aminosilane (Sigma Chemical Co.; St. Louis, Missouri, USA). As lâminas foram imersas em xilol e reidratadas em concentrações decrescentes de etanol. Os sítios imunogênicos foram expostos pelo tratamento enzimático das amostras de pele com pepsina bovina $(10,000$ UTD; Sigma Chemical Co.; St. Louis, Missouri, USA), na concentração de 4 $\mathrm{mg} / \mathrm{ml}$ em ácido acético $0,5 \mathrm{~N}$, ph 2.2 por $30 \mathrm{~min}$, a $37^{\circ} \mathrm{C}$. Após sucessivas lavagens com PBS estas foram incubadas em $5 \%$ de leite desnatado diluído em tampão fosfato ph 7,0. As lâminas foram incubadas durante a noite, a 4 ${ }^{\circ} \mathrm{C}$, com anticorpos policlonais anticolágeno dos tipos I e $\mathrm{V}$ obtidos em camundongos e diluídos 1:20 e 1:50, respectivamente, em tampão fosfato (PBS) e com anticorpo monoclonal anti-colágeno tipo III (Oncogene; San

Diego, USA) diluído 1:50. Para a detecção de TGF- $\beta$ e PDGF, a recuperação antigênica foi feita em alta temperatura com tampão citrato, ph 6,0, durante 30 segundos. Depois do resfriamento por $20 \mathrm{~min}$, as lâminas foram lavadas com PBS, bloqueadas em $5 \%$ de leite desnatado em tampão fosfato ph 7,0 e incubado durante a noite a $4{ }^{\circ} \mathrm{C}$ com anticorpo monoclonal anti-TGF- $\beta$ (Novocastra; New Castle) e PGDF (Novocastra; New Castle), ambos diluídos 1:10. Posteriormente, todas as lâminas foram lavadas várias vezes em PBS $0,05 \%$ de Tween 20 e incubados por 90 min com anticorpo secundário (Anti-IgG de camundongo conjugada com fluoresceína, Sigma; St. Louis, Missouri, USA) diluído 1:50 em PBS contendo 0,006\% de azul de 
Evans. As lâminas foram novamente lavadas várias vezes em PBS 0,05\% Tween 20 e montadas com glicerina tamponada. A reação foi visualizada em microscópio de fluorescência (Nikon).

\section{6 - Estudo Morfológico}

Compartimentos Histológicos: A pele foi histologicamente dividida em três compartimentos anatômicos de referência: a derme papilar, a derme reticular e a derme profunda. As mudanças histológicas nos três compartimentos anatômicos foram então analisadas por avaliação temporal em:

1.) imuno marcação para colágenos tipos I, III e V;

2.) padrão de imunodetecção (homogêneo ou heterogêneo);

3.) aspectos das fibras de colágenos (finas ou espessas).

Medidas semi-quantitativas de alterações histológicas: A gravidade das mudanças histológicas em termos de extensão, intensidade e distribuição não foram homogêneas nos compartimentos anatômicos estudados. Assim, a gravidade destas alterações histológicas foi medida pelo método semi-quantitativo, por dois observadores independentes, de acordo com o seguinte escore:

Escore 1: quando as alterações histológicas foram presentes em 1 a 30\% da derme examinada;

Escore 2: quando as alterações histológicas foram presentes em 31 a 60\% da derme examinada; 
Escore 3: quando as alterações histológicas foram presentes em 61 a 100\% da derme examinada.

\section{7 - TUNEL para tecidos fixados (apoptose)}

Para a realização do TUNEL, com o intuito de verificar a apoptose de células, cortes (3-5 $\mu \mathrm{m})$ de pele das coelhas foram aderidos em lâminas com silane. As lâminas foram desparafinizadas com xilol e consecutivos banhos de álcool em concentrações decrescentes (100\%-70\%), água destilada e PBS gelado (60 min). Para a digestão enzimática os cortes foram incubados com Proteinase-K (Gibco) 20mg/ml, diluída a 1:50 em PBS, por 20 minutos a $37^{\circ} \mathrm{C}$ em banho-maria. Após lavagens com PBS (3 vezes por $5 \mathrm{~min}$ ) sob agitação os cortes foram incubados com Triton $0.1 \%$ em PBS durante 2 minutos sobre o gelo. Para o TUNEL as lâminas foram incubadas com o Kit de apoptose (Roche), diluído 1:9 em azul de Evans (18-45 $\mu \mathrm{l}$ por corte), durante 1 hora a 37oC, em câmara úmida. Após outro ciclo de lavagens as lâminas foram montadas com glicerol $1 \%$.

\section{8 - Coleta de soro}

Amostras de sangue foram obtidas da artéria da orelha de todas as coelhas, coletadas em 0, 150 e 210 dias depois da primeira imunização. Os soros foram separados por centrifugação e congelados a $-70^{\circ} \mathrm{C}$. 


\section{9 - ELISA para colágeno tipos I, III, IV e V}

Placas de microtitulação foram sensibilizadas com $50 \mu$ le colágeno dos tipos I, III, IV e V (Sigma, Chemical Co.; St. Louis, Missouri, USA) numa concentração de $5 \mu \mathrm{g} /$ poço em tampão bicarbonato, $\mathrm{pH} 9,6$, e incubado durante a noite, a $4^{\circ} \mathrm{C}$. As placas foram bloqueadas com BSA $1 \%$ em PBS (Sigma, Chemical Co.; St. Louis, Missouri, USA) por uma hora. As amostras de soro de coelhas foram diluídas 1:100 em BSA 1\% em PBS-0,05\% Tween20 (Sigma, Chemical Co.; St. Louis, Missouri, USA); duplicatas de $50 \mu \mathrm{l}$ foram adicionadas às placas de microtitulação e incubadas por 1 hora em temperatura ambiente. As placas foram lavadas com PBS-0,05\% Tween20 e incubadas com $50 \mu$ l do anticorpo secundário (IgG de cabra antiIgG de coelho, conjugada com fosfatase alcalina; Sigma, Chemical Co.; St. Louis, Missouri, USA) numa diluição de 1:4000 em solução de BSA 1\% em PBS-0,05\% Tween20. A reação foi revelada pela adição de $50 \mu l /$ poço de $1 \mathrm{mg} / \mathrm{ml}$ de p-nitrofenil fosfato (pNPP), diluído em tampão de $1 \mathrm{M}$ de dietanolemina, 0,5 mM de $\mathrm{MgCl}$, $\mathrm{pH}$ 9,8. A densidade ótica foi determinada em um leitor de ELISA (Labsystem Multiskan MS) a 405nm. O "cut off" foi determinado baseado na média de 8 amostras de soros de coelhos normais, somada com o desvio padrão multiplicado por três. O resultado foi expresso em unidade arbitrária (UA), como se segue:

$$
\mathrm{UA}=\frac{\mathrm{DO} \text { amostra }}{\text { Cut off }}
$$




\section{0 - Fator anti-nuclear (FAN)}

Lâminas com células HEp-2 foram usadas para avaliar a presença de FAN nos soros de todos os animais. Após incubação com os soros dos animais diluídos a 1:40, empregou-se anticorpo de cabra anti-lgG de coelho, conjugado com FITC (Sigma, Chemical Co.; St. Louis, Missouri, USA), como anticorpo secundário, numa diluição de 1:50 em azul de Evans 0,003\%. As lâminas foram examinadas em um microscópio de fluorescência (NIKON).

\section{1 - Análise estatística}

Os resultados das análises quantitativas e semi-quantitativas do conteúdo de colágeno foram expressas como média \pm desvio padrão. Os resultados foram avaliados de acordo com a evolução temporal e distribuição das alterações morfológicas e sorológicas em animais imunizados, com indução de tolerância com COL V e controles. A análise descritiva foi seguida pelo teste de ANOVA One-Way para verificar as diferenças das médias entre os grupos de estudo e dentro de cada um deles. Quando necessário, o teste de Bonferroni foi utilizado para identificar as diferenças entre as médias. O nível de significância foi 5\% (SPSS Statistical software). 


\section{1 - Análise Macroscópica}

Após 210 dias da primeira imunização, foi observado na pele dos coelhos intensa e localizada perda de pêlos e presença de múltiplos eritemas em 2 dos 6 animais imunizados com COL $\vee$ (grupo imunizado) (Figura 10, A e B). Por outro lado, estas mesmas alterações não foram notadas nos animais submetidos à indução de tolerância com colágeno do tipo $\mathrm{V}$, bem como no grupo controle.

\section{2 - Análise Histológica}

A avaliação morfológica das amostras de pele dos animais de todos os grupos obtidas pelas colorações de HE e tricrômico de Masson antes da imunização (0 dias) (Fig. 11 A e B; Fig. 12 A e B) foi caracterizada pela manutenção da histoarquitetura da derme e preservação da matriz extracelular. Os anexos cutâneos também estavam preservados (Anex), assim como a camada de tecido adiposo presente na derme profunda. Por outro lado, 150 e 210 dias após a primeira imunização, a pele dos animais imunizados (Fig. 11, C-F) apresentou retificação da epiderme, diminuição da 
derme papilar, atrofia de anexos e a presença de depósito de colágeno na derme reticular e profunda, bem como ao redor de vasos sanguíneos e anexos, mostrando um padrão histológico típico de esclerodermia.

Em 210 dias, a pele dos coelhos, após indução de tolerância (TOLCOL V), apresentou aumento dos anexos cutâneos e diminuição do depósito de colágeno (Fig. 12 E, F), comparado ao grupo controle (Fig. 12 A, B).


Figura 10 - Coelhos após 210 dias da primeira imunização. Em (A) observase perda localizada de pêlos e em (B) a presença de múltiplas lesões eritematosas em áreas expostas. 



Figura 11 - Pele de coelhos imunizados em 0, 150 e 210 dias, corados por H\&E (lado esquerdo) e tricrômico de Masson (lado direito). Em A e B, pele de coelho antes da imunização $(\mathrm{t}=0)$ mostrando manutenção da arquitetura da derme papilar, tecido conjuntivo e anexos cutâneos preservados (Anex). Em contraste, 150 (C e D) e 210 (E e F) dias após a primeira imunização, a pele dos animais imunizados mostrou uma modificação linear da epiderme e progressiva diminuição da derme papilar, atrofia de anexos e deposição de colágeno na derme profunda e reticular, bem como em volta dos vasos e anexos (100X, A-H). 



Figura 12 - Peles de coelhos coradas por H\&E e tricrômico de Masson. Em A e B, pele de aminal antes da imunização $(\mathrm{t}=0)$, mostra manutenção da arquitetura da derme papilar e tecido conjuntivo, com preservação da matriz extracelular, presença de vários anexos cutâneos (Anex) e camada adiposa na derme profunda. Em C e D, pele de coelhos imunizados antes da indução de tolerância nasal (150 dias), mostra modificação linear da epiderme e diminuição da derme papilar, atrofia de anexos e deposição de colágeno na derme reticular e profunda, bem como em volta dos vasos e anexos, similar ao padrão da esclerodermia. Em E e $\mathrm{F}$, a pele dos animais após indução de tolerância nasal com COL V (210 dias), mostrou a presença de mais anexos cutâneos e diminuição do colágeno comparado com a pele de coelhos antes da indução de tolerância (40X, AF; A, C e E, H\&E; B, D e F, tricrômico de Masson. 


\section{3 - Análise Quantitativa do Colágeno}

A análise das fibras de colágeno, pelo picro sirius, das peles dos coelhos antes da imunização (0 dias) (Fig. 13 A), 150 dias (Fig. 13 B) após a imunização e em coelhos imunizados e com indução de tolerância com COL V (TOL-COLV, 210 dias) (Fig. 13 C), demonstrou uma diminuição da birrefringência das fibras colágenas nas peles dos animais com indução de tolerância (Fig. 12 C), muito semelhante ao observado na pele de animais dos grupos controle (Figura $12 \mathrm{~A}$ ).

A tabela 3 demonstra a quantidade de colágeno nas amostras de pele das coelhas em 0, 150 e 210 dias de todos os grupos. Foi observada uma diferença estatisticamente significativa entre o grupo dos animais controle e

o grupo dos imunizados com 210 dias (imunizado) $(p<0,01)$; e entre o grupo de animais imunizados com 210 dias (grupo imunizado) e o grupo com indução de tolerância para colágeno tipo $V$ (TOL-COL $V, 210$ dias) $(p=$ 0,002) (Gráfico 1). 

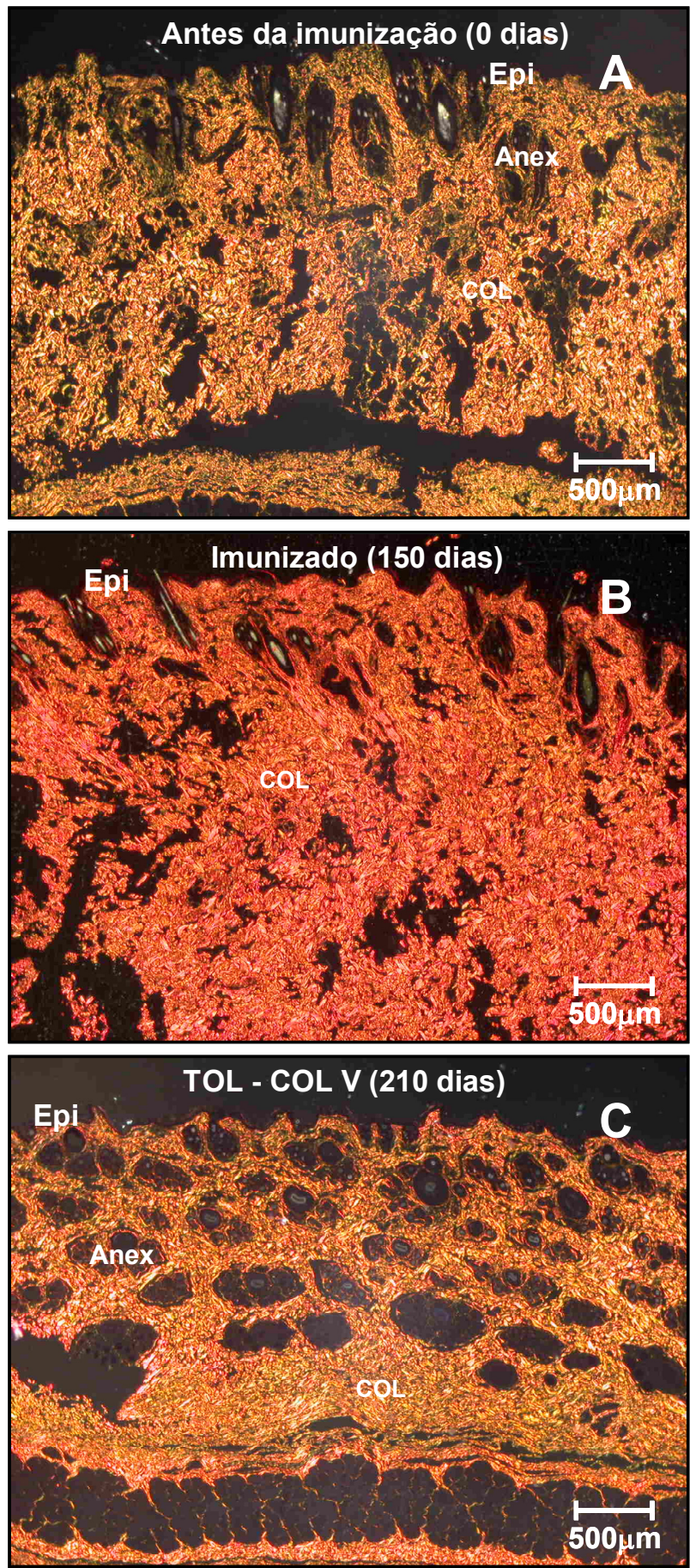

Figura 13 - Peles de coelhos coradas Sirius red. Em A, pele de aminal antes da imunização $(t=0)$, birrefringência das fibras de colágeno com um padrão normal, com preservação da matriz extracelular, presença de vários anexos cutâneos (Anex) e camada adiposa na derme profunda. Em B, pele de coelhos imunizados antes da indução de tolerância nasal (150 dias) mostra intensa birrefringência das fibras de colágeno, mais acentuada na derme reticular e profunda; diminuição da derme papilar e atrofia de anexos, similar ao padrão da esclerodermia. Em C, a pele dos animais após indução de tolerância nasal com COL V (210 dias), houve diminuição da birrefringência das fibras de colágeno, presença de mais anexos cutâneos em relação à pele de coelhos antes da indução de tolerância (40X, A-C; Sirius red). 
Tabela 3 - Porcentagem de fibras de colágeno por fração de área de pele dos coelhos dos grupos controle, imunizado e TOL- COL V (grupo com indução tolerância nasal com colágeno tipo V)

\begin{tabular}{|c|c|c|c|}
\hline GRUPOS & 0 dias & 150 dias & 210 dias $^{*}$ \\
\hline $\begin{array}{c}\text { Controle } \\
(n=6)\end{array}$ & $26 \% \pm 0,06$ & $32 \% \pm 0,02$ & $30 \% \pm 0,05$ \\
\hline $\begin{array}{c}\text { Imunizado } \\
(n=6)\end{array}$ & $27 \% \pm 0,02$ & $38 \% \pm 0,05$ & $40 \% \pm 0,01$ \\
\hline $\begin{array}{c}\text { TOL-COLV } \\
(n=6)\end{array}$ & $23 \% \pm 0,02$ & $41 \% \pm 0,09$ & $31 \% \pm 0,02$ \\
\hline
\end{tabular}

Gráfico 1 - Fração de área das fibras de colágeno na pele de coelhos dos grupos controle, imunizados e imunizados submetidos a indução de tolerância nasal com colágeno tipo $\mathrm{V}$ (TOL - COL V), no período de 210 dias após a primeira imunização (ANOVA One-Way e Bonferoni).

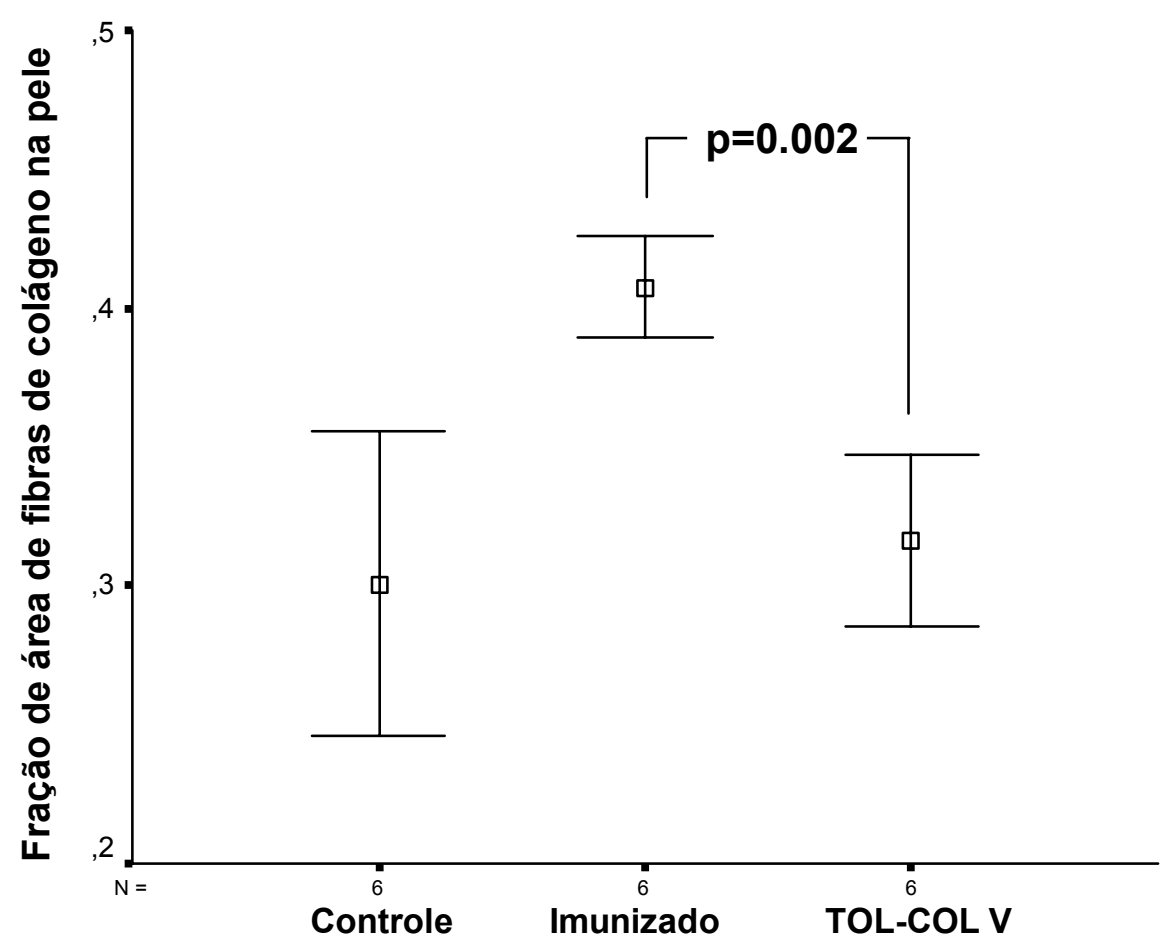




\section{4- Análise da Imunodetecção dos tipos de Colágeno}

A imunomarcação para colágeno tipo I (COL I) apresentou um padrão homogêneo desta proteína na região da derme superficial e reticular em todas as coelhas controle (Figura 14, A, B, C e E). Entretanto, após 150 e 210 dias (Figura 14, D e F), o COL I apresentou um padrão de marcação denso e heterogêneo na derme profunda, em volta dos anexos cutâneos e substituição da camada adiposa da derme profunda por depósito de fibras colágenas, semelhante ao padrão morfológico da pele de pacientes com esclerodermia. A pele das coelhas com indução de tolerância (TOL-COL V, 210 dias) apresentou um padrão de marcação homogêneo, caracterizado pela baixa intensidade do colágeno I ao redor dos anexos (Figura $14 \mathrm{G}$ ), na derme superficial e profunda semelhante ao grupo controle (Figura $14 \mathrm{H}$ ).

Do mesmo modo, a imunomarcação do colágeno tipo III (COL III) nas amostras de pele dos animais controle apresentou um padrão fibrilar fino, característico do padrão fibrilar normal das fibras deste tipo de colágeno (Figura 15 A, B, C e E). Por outro lado, a pele das coelhas imunizadas, examinadas após 150 e 210 dias, revelou intensa expressão de colágeno tipo III (COL III), envolvendo a derme superficial e profunda (Figura 15 D e F), ao contrário dos animais submetidos à indução de tolerância, que apresentaram diminuição na expressão deste tipo de colágeno em todas as regiões da pele (Figura $15 \mathrm{G} \mathrm{e} \mathrm{H}$ ).

A imunomarcação do colágeno do tipo $\mathrm{V}(\mathrm{COL} V)$ nas amostras de pele das coelhas do grupo controle mostrou baixa expressão desta proteína, exibindo um padrão fibrilar fino na região da membrana basal. (Figura $16 \mathrm{~A}$, 
B, C e E ). Por outro lado, na pele de coelhas imunizadas, o COL V estava fortemente marcado na forma de fibras grossas ao longo da derme papilar e profunda (Figura 16 D e F), mostrando um padrão fibrilar estrutural anormal. Após a indução de tolerância, houve diminuição significativa da expressão deste tipo de colágeno, com retorno ao padrão fibrilar fino semelhante ao encontrado no grupo controle (Figura $16 \mathrm{G} \mathrm{e} \mathrm{H)}$ ).

O remodelamento de colágeno foi também correlacionado com a expressão de citocinas fibrogênicas, sendo o TGF- $\beta$ e o PDGF mais expressos em 150 (Figura 17 C e D) e 210 dias (Figura 16 E e F) nos animais imunizados (Grupo imunizado), apresentando, após a indução de tolerância nasal com COL V (TOL-COL V, 210 dias), uma diminuição na expressão destas citocinas (Figura $17 \mathrm{G} \mathrm{e} \mathrm{H}$ ). 



Figura 14 
Figura 14 - Imunofluorescência para o colágeno do tipo I em amostra de pele de coelhos controles, imunizados e tolerados. Em A, C e E, pele de animais controle em 0,150 e 210 dias, respectivamente, mostra um padrão homogêneo do colágeno do tipo I na região subepidérmica e na derme reticular da pele de todos os coelhos controles. Em B, foi encontrado um padrão similar para o controle de pele do colágeno do tipo I antes da imunização (0 dias) de animais imunizados. Em D e F, o colágeno do tipo I dos coelhos imunizados após 150 e 210 dias, respectivamente, expressam um padrão denso heterogêneo na derme profunda, ao redor dos anexos e por todo o tecido adiposo. Em G e H, o colágeno do tipo I de coelhos tolerados mostram um padrão homogêneo, baixa intensidade de imunofluorescência ao redor dos anexos, na derme superficial e profunda, similar ao grupo controle (100X, A-H). 

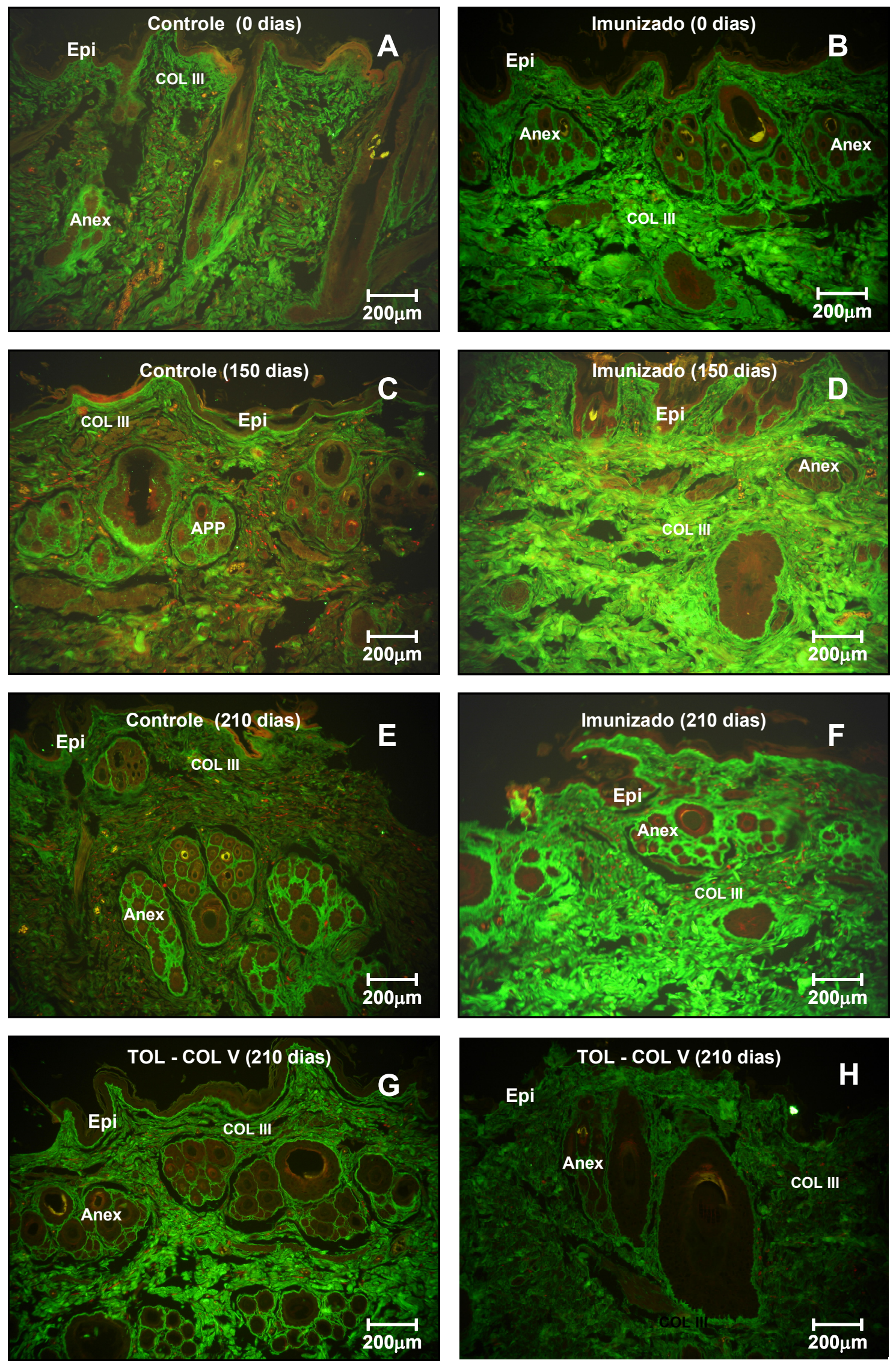

\section{Figura 15}


Figura 15 - Imunofluorescência para o colágeno do tipo III em amostra de pele de coelhos controle, imunizados e tolerados. Em A, C e E, pele de animais controle em 0,150 e 210 dias, respectivamente, mostram um padrão de fibras finas do colágeno do tipo III (COL III) observadas na região papilar da derme. Em B, foi encontrado um padrão similar ao controle de pele em 0 dias (antes da imunização). Em D e F, o colágeno do tipo III (COL III) dos coelhos imunizados após 150 e 210 dias, respectivamente, mostra uma forte expressão na derme superficial e profunda. Em G e H, a pele dos animais após indução de tolerância nasal, mostra menor expressão do colágeno do tipo III na derme superficial e profunda (100X, A-H). 

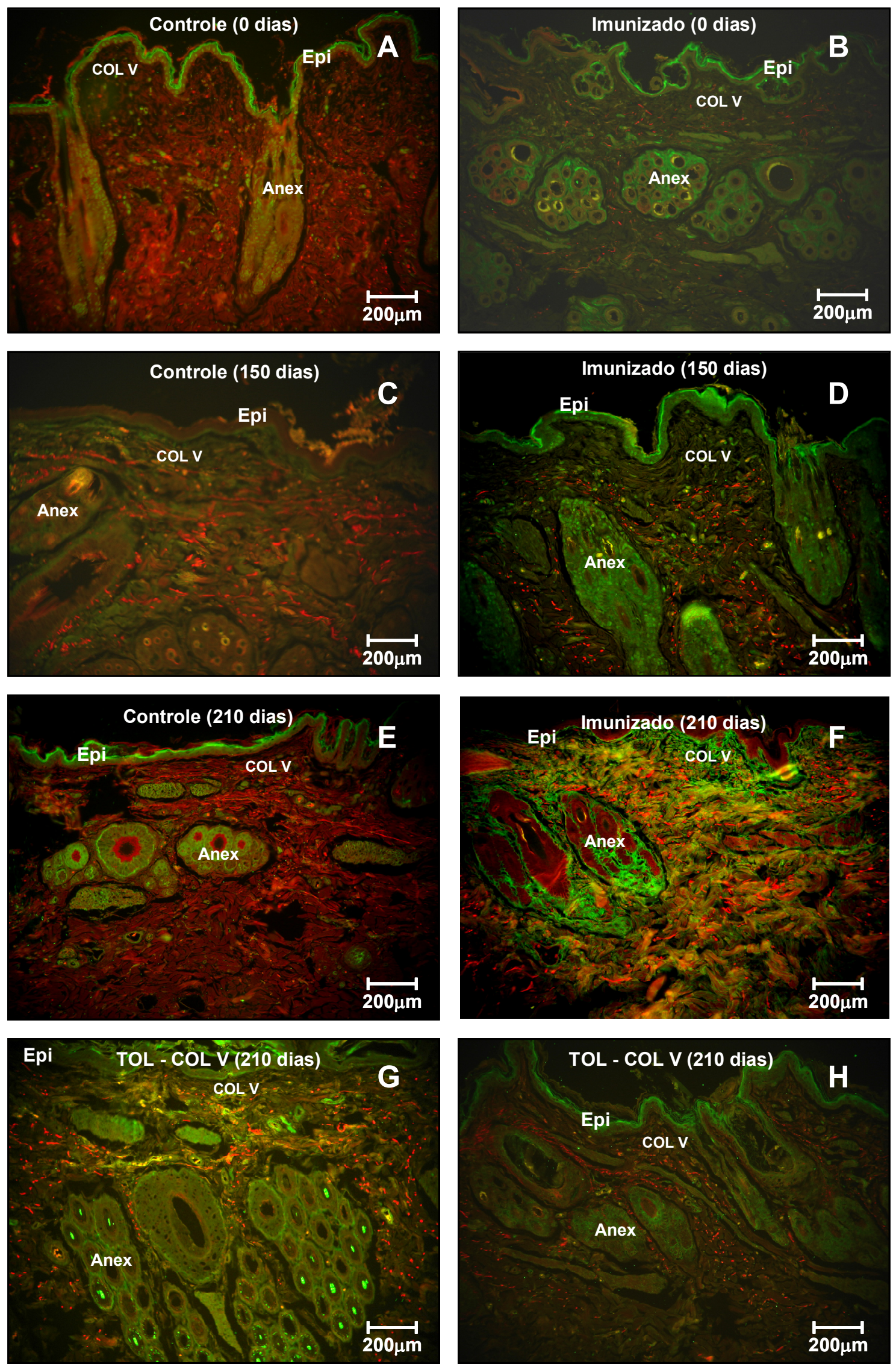

Figura 16 
Figura 16 - Imunofluorescência para o colágeno do tipo $\mathrm{V}$ em amostras de pele de coelhos controle, imunizados e tolerados. Em A, C e E, pele de animais controle após 0,150 e 210 dias respectivamente, mostrando uma baixa expressão do colágeno do tipo $\mathrm{V}(\mathrm{COL} \mathrm{V})$, em um padrão de fibras finas na região da membrana basal. Em B, foi encontrado um padrão similar ao controle do colágeno do tipo $\mathrm{V}$ em pele antes da imunização (0 dias). Em $\mathrm{D}$ e $\mathrm{F}$ o colágeno do tipo $\mathrm{V}$ de coelhos imunizados após 150 e 210 dias, respectivamente, mostram um padrão de fibras grossas em volta da derme papilar e profunda. Em G e H, pele de coelhos após indução de tolerância nasal, mostra um padrão de fibras finas na região da membrana basal e derme profunda (100X, A-H). 

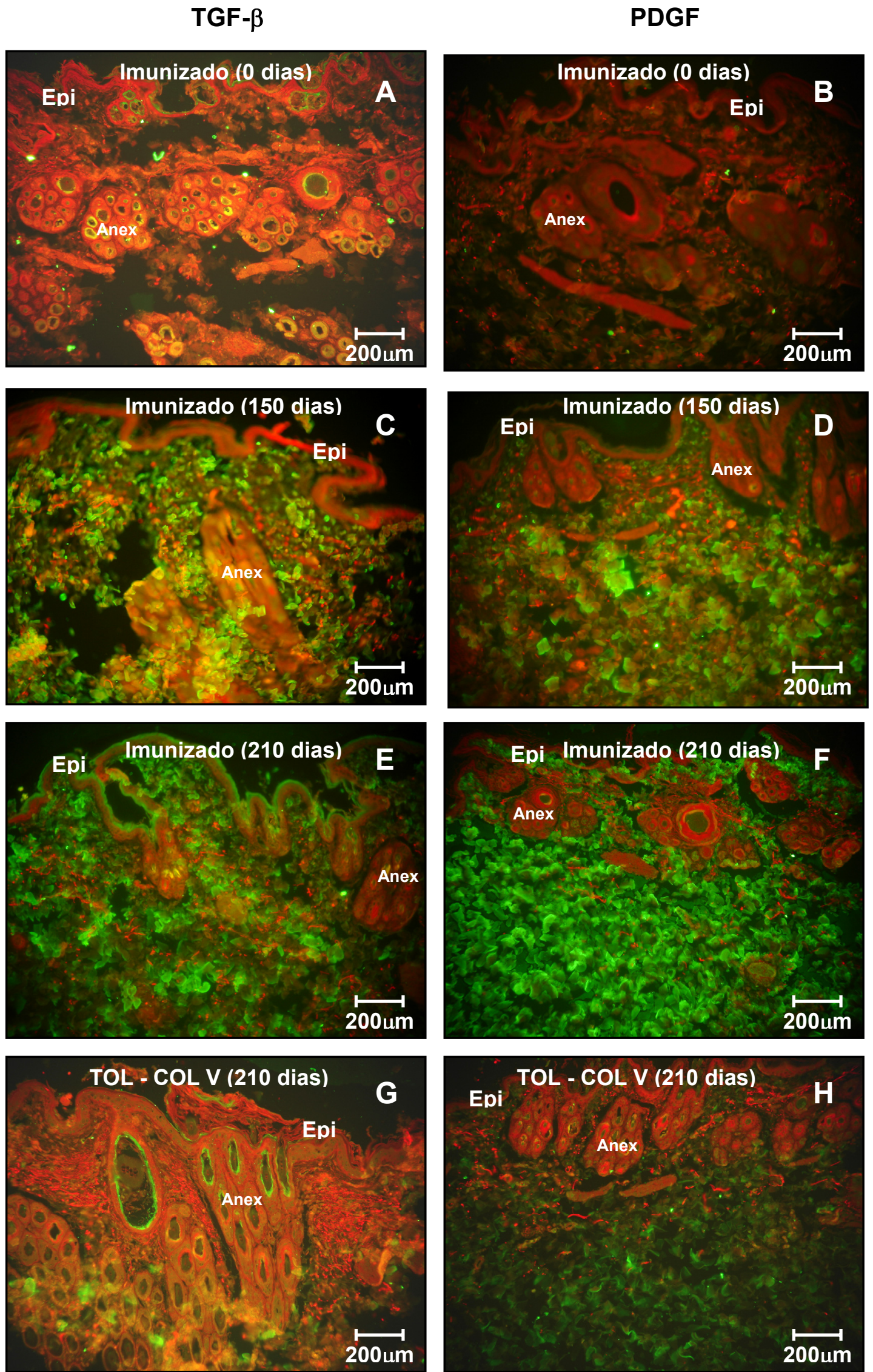

Figura 17 
Figura 17 - Imunoflurescência ao TGF- $\beta$ (lado esquerdo) e PDGF (lado direito) em amostras de pele de coelhos imunizados e tolerados. A e B mostram expressão do TGF- $\beta$ e do PDGF, respectivamente em pele de coelhos antes da imunização com colágeno do tipo $\mathrm{V}$ ( 0 dias). C e $\mathrm{E}$ mostram um a alta expressão do TGF- $\beta$ em 150 e 210 dias, respectivamente, em coelhos imunizados. D e E mostram maior expressão do PDGF em 150 e 210 dias, respectivamente, em coelhos imunizados. Em contraste, $G$ e $H$ mostram uma diminuição do TGF- $\beta$ e PDGF, respectivamente na pele de coelhos após indução de tolerância nasal com COL V. (100X, A-H). 


\section{5 - Análise Semi-quantitativa de Colágeno}

A análise morfológica semi-quantitativa dos tipos de colágeno confirmou os achados histológicos obtidos pelo HE, tricrômico de Masson e Picrosírius, onde foi demonstrada a presença de fibrose na pele dos animais imunizados e diminuição do depósito de colágeno após a indução de tolerância em relação ao grupo controle (Gráfico 2). Após 150 dias da primeira imunização, foi encontrado um aumento significativo dos colágenos dos tipos I $(p<0.01)$, III $(p<0.01)$ e $V(p=0.119)$ em animais imunizados, em comparação com os dos grupos controle, bem como entre animais dos grupos controle e com indução de tolerância, para o colágeno dos tipos I ( $p$ $=0.033)$, III $(p<0.01)$ e V $(p=0.020)$

Por outro lado, após a indução de tolerância com colágeno tipo $\mathrm{V}$ (TOL-COLV, 210 dias), a pele das coelhas apresentou significativa diminuição do colágeno dos tipos I $(p=0.002)$, III $(p=0.025)$ e V $(p=0.005)$ em relação ao grupo imunizado (Gráfico 2).

\section{6 - TÚNEL (apoptose)}

A reação do TÚNEL demonstrou ocorrência de apoptose de células em pele das coelhas do grupo imunizado com colágeno tipo $V$ em 210 dias (Fig 18, B) em relação aos do grupo controle (Fig 18, B). Não foi observada apoptose significativa das células da pele dos animais após indução de tolerância com colágeno tipo V (TOL-COL V, 210 dias) (Fig 18, C). 
Gráfico 2 - Remodelamento dos colágenos tipos I, III e V na pele dos coelhos dos grupos controle, imunizado e TOL-COL V (indução de tolerância com colágeno V).

Colágeno tipo I

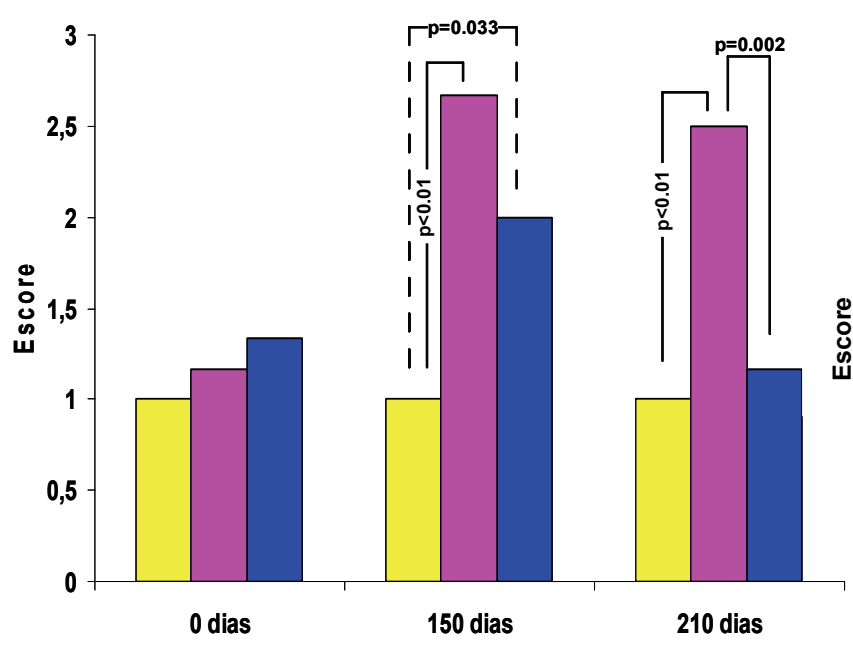

Colágeno tipo V

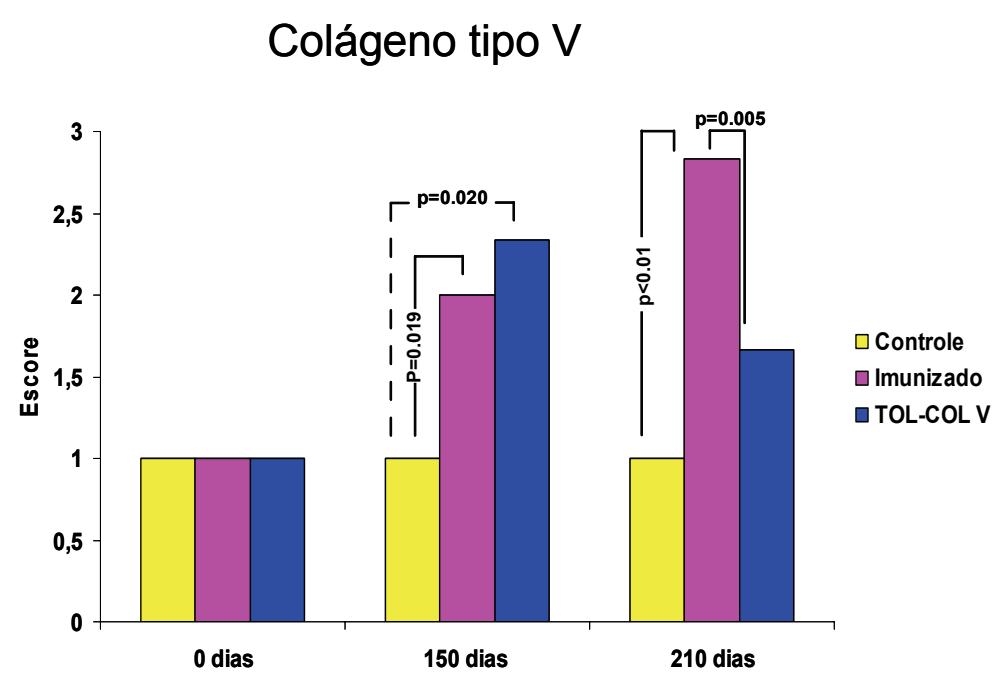

Colágeno tipo III

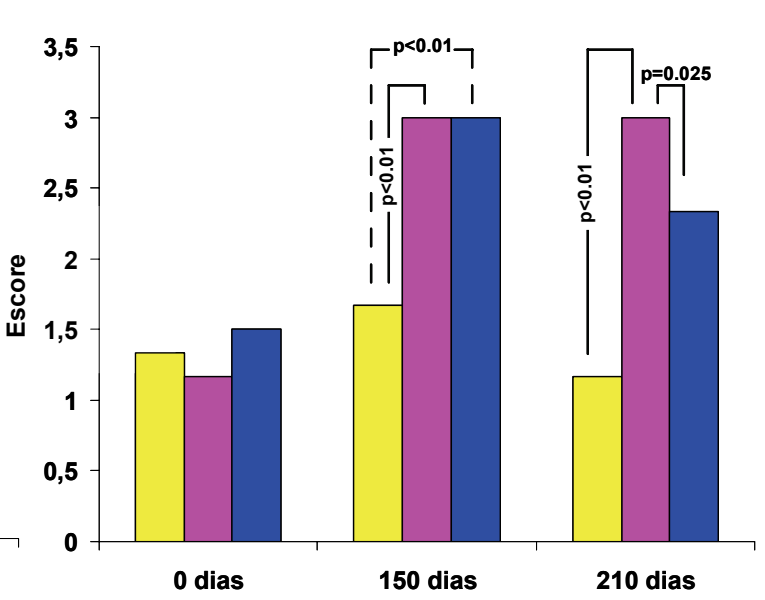



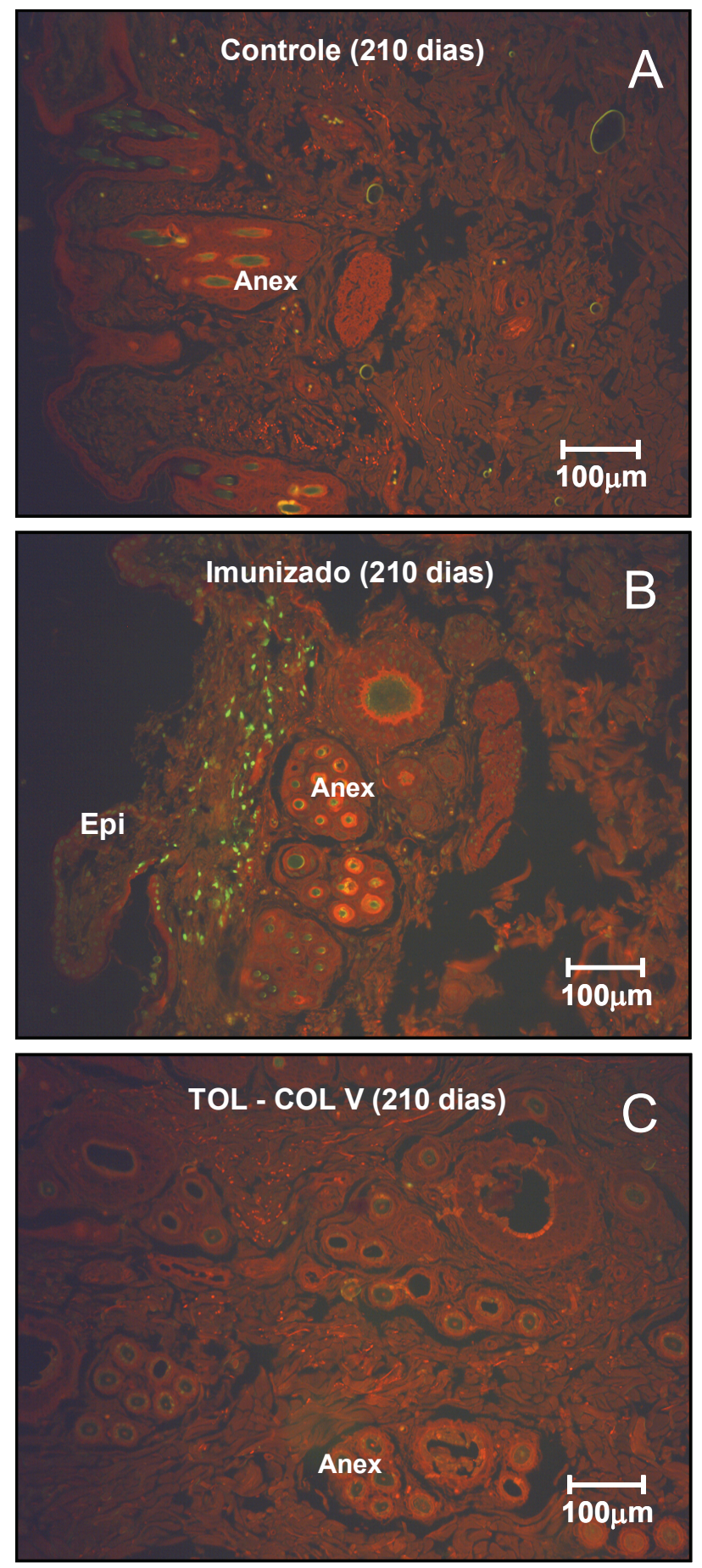

Figura 18 - Apoptose de células de pele (TUNEL). Em (A) animal controle com 210 dias. Em (B) pele das coelhas do grupo imunizado com colágeno tipo $\mathrm{V}$ em 210 dias mostrando ocorrência de apoptose de células. Em (C) não foi observada apoptose significativa das células da pele dos animais após indução de tolerância com colágeno tipo V (TOL-COL V, 210 dias). 


\section{7 - Determinação de anticorpos aos colágenos dos tipos I, III, IV e V}

O soro de coelhas imunizadas com colágeno tipo $\mathrm{V}$ (grupo imunizado) apresentou expressão estatisticamente significativa de anticorpos anticolágeno dos tipos III $(p<0.01)$, IV $(p<0.01)$ e V $(p<0.01)$, em relação ao grupo controle em 150 e 210 dias (Tabela 4). Após a indução de tolerância com colágeno V (TOL-COLV, 210 dias), não foi encontrada diferença estatística para os anticorpos anti-colágeno dos tipos III, IV e V em relação ao grupo apenas imunizado (Tabela 4). Não se identificou anticorpos anticolágeno I em todos os grupos estudados.

Tabela 4 - Expressão de anticorpos anti-colágeno dos tipos I, III, IV e V no soro de animais dos grupos controle, imunizado e TOL-COL V.

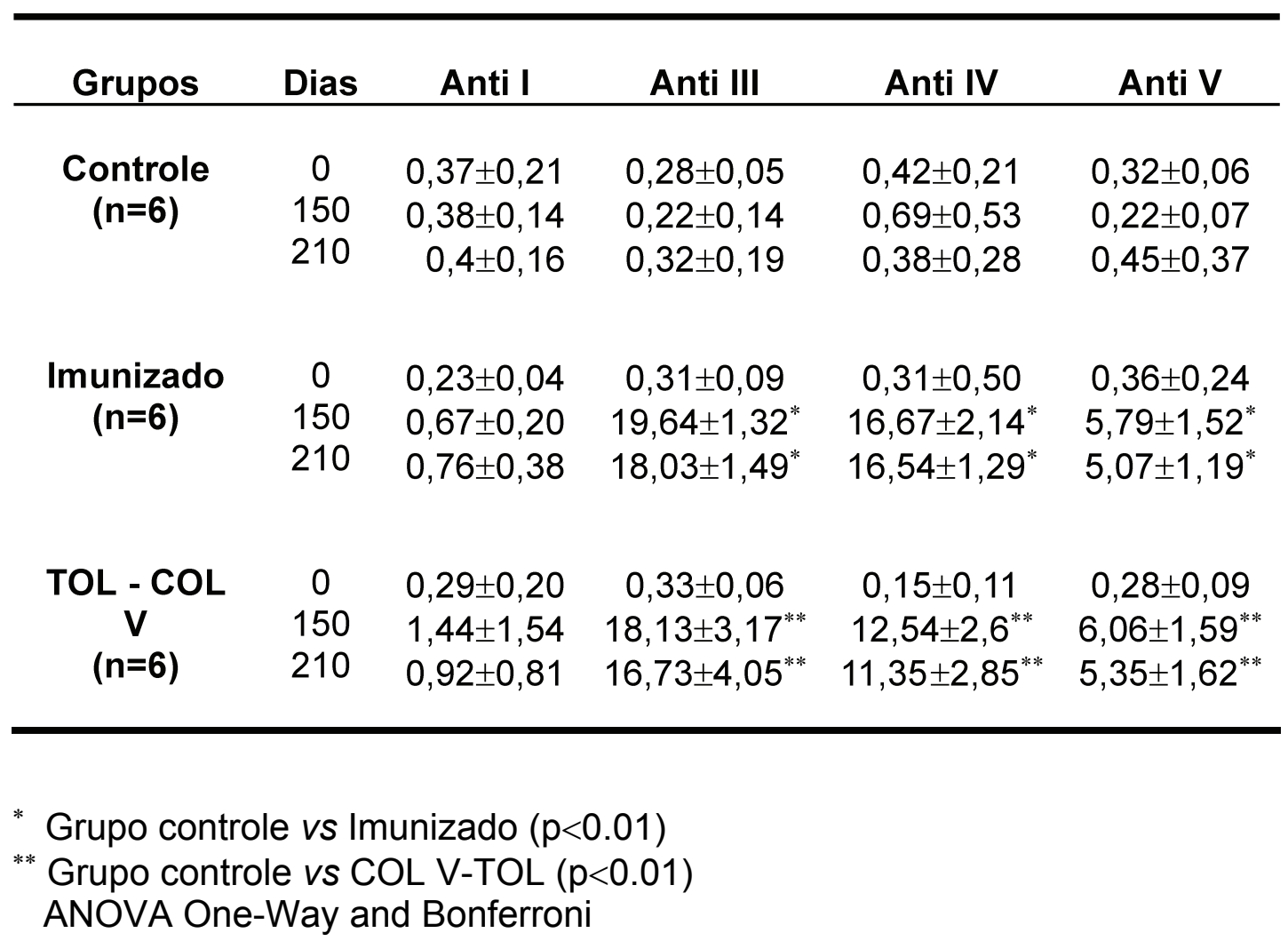




\section{8 - Determinação de Anticorpos Anti-nucleares (FAN)}

Cerca de $90 \%$ dos animais imunizados com colágeno tipo V apresentaram anticorpos dirigidos para antígenos citoplasmáticos (tabela 5). Os animais imunizados exibiram dois padrões de imunofluorescência, um caracterizado como citoplasmático fino, marcado próximo da membrana nuclear, e o outro com a demonstração de grânulos densos próximo à membrana nuclear (figura 19, A e B). Este padrão de imunomarcação foi mais freqüente nos soros dos animais imunizados de 210 dias em relação aos do grupo com indução de tolerância com colágeno V (TOL-COL V, 210 dias) (figura 19, A e B).

Tabela 5 - Freqüência de fator anti-núcleo (FAN) nos animais dos grupos controle, imunizado e tolerado.

\begin{tabular}{lccc}
\hline Grupos & 0 dias & 120 dias & 210dias \\
\hline Controle $(\mathrm{n}=6)$ & 1 & 0 & 1 \\
Imunizado & 0 & 5 & 5 \\
Tolerado & 0 & 5 & 4 \\
\hline
\end{tabular}



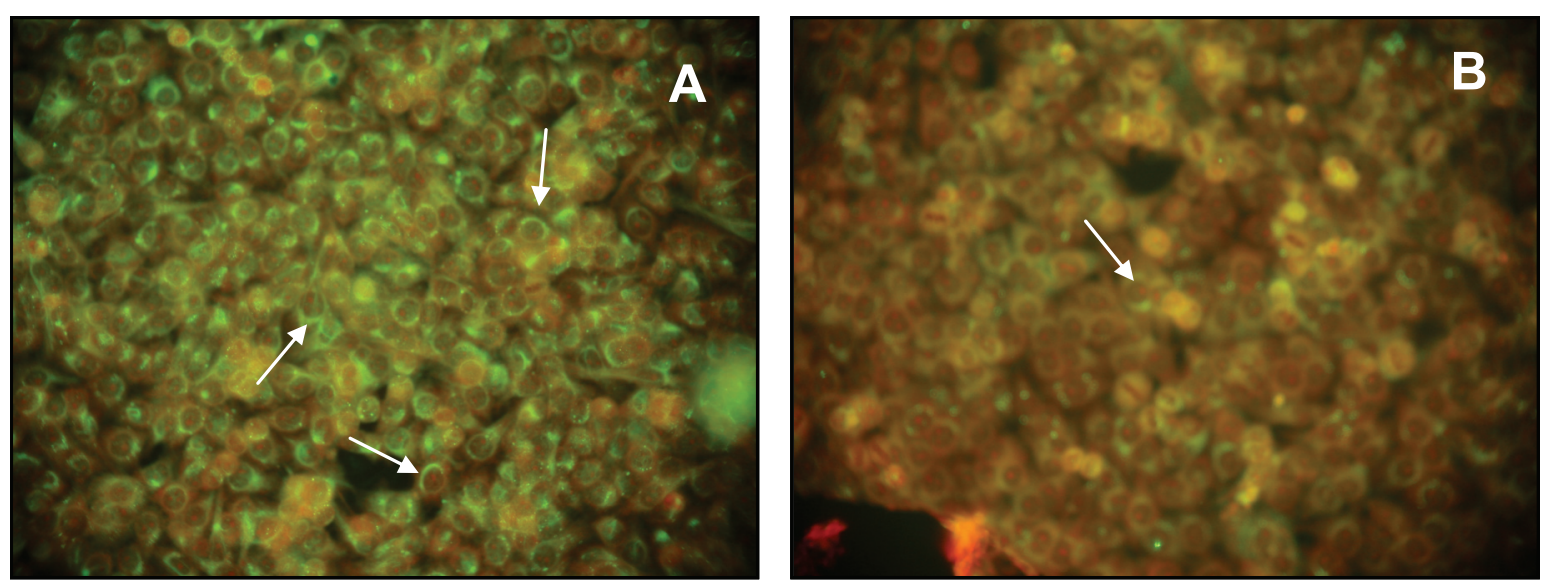

Figura 19 - Imunofluorescência para FAN, em células HEp-2. Em A, presença de densa coloração próxima a membrana nuclear. Em B, coloração fina citoplasmática próxima à membrana nuclear (200X, A-B). 
Este estudo tem o propósito de verificar se a indução de tolerância nasal para COL $\mathrm{V}$ é capaz de suprimir alterações morfológicas e imunológicas, observadas em coelhos imunizados com $\mathrm{COL} V$, que desenvolvem inúmeros aspectos compatíveis com as observadas na esclerodermia (Vilas et al., 2002; Wigley, 1999). Inclusive, em estudos anteriores, houve demonstração da existência de similaridades histológicas e imunológicas entre este modelo animal e os apresentados pelos pacientes com SSc (Yoshinari et al., 2002; Teodoro et al., 2003; Teodoro et al., 2004; Yoshinari et al., 2005; Souza et al., 2005; Bezerra et al., 2006). Esta terapêutica alternativa em animais de experimentação, se conduzida com sucesso, poderia ser um excelente tratamento para os pacientes com esclerodermia.

O objetivo da tolerância é o de suprimir a reatividade imune específica, sem afetar o sistema imunológico como um todo, através da administração de antígenos por via das mucosas (nasal ou oral), teoricamente implicados na patogênese de doenças autoimunes, processos 
alérgicos ou rejeição de transplante de órgãos. Os mecanismos de indução de tolerância pela administração de antígenos dependem da dose utilizada (Faria e Weiner, 1999; Weiner, 2001; Faria e Weiner, 2005). Altas doses administradas por via nasal induzem deleção ou anergia de células $T$, enquanto que baixas doses promovem ativação de células $\mathrm{T}$ regs, geralmente dos seguintes subtipos: Th2 (secretoras de IL-4, IL-10 e TGF- $\beta$ ), TH3 (secretoras de TGF- $\beta$ ) e Tr1 (secretoras de IL-10 e IL-4, e menos TGFß) (Weiner, 2001; Jonuleit e Schmit, 2003).

Normalmente, as células $T$ regs presentes nas mucosas participam na preservação do equilíbrio imunológico, evitando a formação de clones autoreativos. As células regulatórias Tr1 predominam nos nódulos linfáticos do pulmão e as Th3 são predominantes no intestino (Akbari et al., 2001; Weiner, 2001). Uma vez ativadas por antígenos específicos, as células T regs suprimem a resposta celular de um modo independente de antígeno. Este fenômeno é referido como uma supressão "bystander" (Miller et al., 1991). Visto que TGF- $\beta$ e IL10 são citocinas imunosupressoras, capazes de bloquear a proliferação de células T, a tolerância nasal (ou oral) para um antígeno específico envolvido em doenças autoimunes está sendo utilizada com sucesso como terapêutica em modelos animais e doenças em humanos, tais como: uveite, encefalomielite, diabetes, artrite reumatóide e outras (AR) (Wolfraim, 2006).

Existe uma vasta publicação em literatura médica, demonstrando os efeitos da indução de tolerância nasal ou oral com colágeno tipo II, com peptídeos de colágeno, além dos colágenos tipos IX e XI, na prevenção e 
tratamento de artrite reumatóide experimental (Yoshino, 1995; Khare et al., 1995; Garcia et al., 1999; Faria e Weiner, 1999; Prakken et al., 2002). Além disso, ensaios clínicos têm mostrado a eficácia da indução de tolerância, principalmente com baixas doses de colágeno tipo II, no tratamento de artrite reumatóide em seres humanos (Wolfrain, 2006). Recentemente, foram encontradas células $\mathrm{T}$ regs $\left(\mathrm{CD} 4^{+} \mathrm{CD} 25^{+}\right)$, produtoras de $\mathrm{IL}-10$, após a indução de tolerância oral, com baixas quantidades de colágeno tipo II, em um modelo de artrite reumatóide em camundongos da linhagem DBA/1 (Mine t al., 2003). Isto demonstra a participação de mecanismos regulatórios de supressão imune na indução de tolerância oral com colágeno tipo II. Ainda, a administração nasal de um peptídeo alterado ligante, análogo a um epítopo artritogênico (Hsp60), induziu um grande efeito de proteção contra a artrite induzida por antígeno através da geração de células $T$ regs, que produziram IL-4, TGF- $\beta$ e IL-10 (Prakken et al., 2002). Este trabalho demonstrou que a tolerância induzida era dirigida principalmente por IL-10.

Pouco se sabe sobre a indução de tolerância no tratamento da ES. Em trabalho recente, Mackown et al., (2001) realizaram indução de tolerância imunológica em pacientes com ES através da administração oral de colágeno tipo I bovino. Este estudo revelou que os pacientes tolerados oralmente apresentaram diminuição de resposta imune dependente de células T para colágeno tipo I "in vitro" e uma considerável melhora clínica.

Recentemente, o colágeno tipo $\mathrm{V}$ foi considerado um autoantígeno potencial, capaz de desencadear doença autoimune ou de induzir rejeição de transplante de pulmão (Mares et al., 2000; Haque et al., 2002). Nosso 
grupo descobriu que animais imunizados com COL V, com propósito inicial de produzir anticorpos para esta proteína, desenvolveram lesões macroscópicas no pulmão, sugestivo de vasculite. Este fenômeno foi reprodutível com outros animais, também imunizados com COL $V$, e a análise histológica do tecido pulmonar confirmou a presença de lesões vasculares microscópicas, associadas com processo de remodelamento, devido ao depósito de colágeno nos vasos e no parênquima pulmonar. No início, pensamos em um modelo experimental de vasculite, mas a presença de intensa proliferação da camada fibrointima, oclusão do lúmen do vaso e lesão endotelial sugeriram tratar-se de possível modelo experimental de ES. Estudos histológicos adicionais realizados em órgãos normalmente afetados em esclerodermia confirmaram a nossa hipótese (Yoshinari et al., 2002; Teodoro et al., 2003; Teodoro et al., 2004; Bezerra et al., 2006).

Interessantemente, na mesma época, outro grupo de pesquisadores descobriu que o $\mathrm{COL} V$ seria o antígeno responsável pela rejeição do enxerto de pulmão no modelo murino de transplante pulmonar (Mares et al., Haque et al., 2002; Wilkes, 2003; Sumpter e Wilkes, 2004; Yoshida et al., 2006. Os autores sugeriram que o processo inflamatório gerado durante o fenômeno de rejeição do transplante de pulmão ocasionaria a exposição de fragmentos de COL $V$ oculto, com a participação de metaloproteases, originando uma doença de enxerto versus hospedeiro, direcionados para epítopos desta molécula. Além do mais, este grupo demonstrou que a tolerância oral com COL $V$ inibiu a rejeição aguda do enxerto de pulmão, impedindo o desenvolvimento de bronquiolite obliterante, principal fator 
causal da morte nos transplantes de pulmão tanto em modelo experimental de camundongos, como em humanos (Yasufuku et al., 2001; Yasufuku et al., 2002; Mizobuche et al., 2003; Wilkes e Sumpter, 2004).

Algumas evidências conduziram-nos a pesquisar a indução da tolerância nasal com COL $\mathrm{V}$ em modelo experimental de esclerodermia, descoberto pelo nosso grupo: 1 - existência de semelhanças entre doença de enxerto versus hospedeiro com a ES (Siimes et al., 1977; Furte et al., 1979; Bell et al., 1996); 2 - fortes evidencias de que a esclerodermia é uma doença $\mathrm{T}$ dependente para um possível antígeno, ainda desconhecido (Sakkas et al., 2002); 3 - o próprio fato de que a imunização de coelhos sadios com colágeno tipo $\mathrm{V}$ desencadeia uma série de alterações histológicas e sorológicas, muito semelhantes à esclerodermia em humanos; 4 - prevenção de rejeição do transplante de pulmão por tolerância oral com COL V. Postulamos que, a exemplo do que ocorre na rejeição de transplante pulmonar, a introdução do colágeno tipo $\mathrm{V}$ em coelhas sadias, por razões ainda desconhecidas, geraria neoantígenos "self" (fragmentos ocultos do COL $\mathrm{V}$ presente nas fibrilas heterotípicas), desencadeando processo de remodelamento matricial com depósito de colágeno e manifestações de auto-imunidade. Este neoantígeno poderia estar envolvido na patogênese da ES, via ativação da resposta celular T dependente.

Neste estudo, escolhemos a tolerância nasal, em vez de oral, devido à necessidade de menor quantidade de $\mathrm{COL} V$ para a execução da pesquisa, além de não haver a degradação desta proteína quando administrada por esta via. Além disso, trabalhos recentes demonstram uma 
grande eficácia da tolerância nasal na profilaxia e tratamento de várias doenças autoimunes experimentais e em humanos (Bai e Link, 2000; Prakken et al., 2002). Ainda, aliado ao fato de que baixas doses de antígeno sugerem promover a ativação de células $\mathrm{T}$ regs, principal mecanismo observado no emprego da tolerância nasal, que leva à produção de citocinas imunossupressivas (Prakken et al., 2002; Taylor et al., 2006).

Acredita-se que a tolerância nasal ative as células $\operatorname{Tr} 1$ regs, produtoras de IL-10, as quais são normalmente encontradas nos nódulos linfáticos pulmonares (Akbari et al., 2001). Por outro lado, estudos têm demonstrado que a ativação de células $T$ regs depende do microambiente de citocinas presente nas mucosas; assim, como o intestino é rico em TGF$\beta$, preferencialmente células Th3, produtoras de TGF- $\beta$, são desencadeadas por tolerância oral (Weiner et al., 2001). O TGF- $\beta$ é uma citocina com várias ações, pois além da sua função imunossupressora, apresenta uma potente ação fibrogênica e poderia piorar a fibrose no modelo experimental de ES (Falanga et al., 1992; Yamakage et al., 1992; Nabel et al., 1993; Denton et al., 2005). Optamos pela análise morfológica e histológica da pele, em detrimento do estudo em outros órgãos, pois este é um tecido preferencialmente acometido nas várias formas de ES em seres humanos. Os demais órgãos foram conservados para posterior pesquisa. Além disso, a pele, pelo fácil acesso, nos dá a possibilidade de realizar biópsias seqüências no mesmo animal, importantes para analisar o efeito da indução de tolerância nasal com colágeno tipo $\mathrm{V}$ no modelo experimental de ES. 
Os resultados foram surpreendentes. Pela primeira vez, dois dos seis animais imunizados com COL V e mantidos até 210 dias apresentaram lesões macroscópicas na pele, caracterizadas pela perda localizada de pêlos, com surgimento de lesões eritematosas nas áreas expostas. Provavelmente esta manifestação não foi previamente encontrada, devido ao fato dos animais não terem sido mantidos por período tão prolongado após o início das imunizações.

As análises histológicas confirmaram que os animais imunizados com COL V desenvolveram progressiva retificação da epiderme, diminuição da derme papilar, atrofia de anexos cutâneos e depósito de colágeno na derme reticular e profunda. Por outro lado, os animais submetidos à indução da tolerância exibiram reversão destes aspectos histológicos, ocorrendo aumento de anexos cutâneos e decréscimo no conteúdo de colágeno, quando comparado com as peles destes animais, previamente à tolerância.

A analise quantitativa do conteúdo de colágeno da pele, mostrou que houve uma diferença significativa entre os animais controle e imunizados após 210 dias da primeira imunização. Por outro lado, as coelhas induzidas com tolerância nasal mostraram um decréscimo significante do conteúdo de colágeno, quando comparado com os animais imunizados no período de 210 dias.

A imunomarcação para colágeno revelou aumento do depósito de colágeno dos tipos I, III, e V na pele dos coelhos imunizados aos 150 e 210 dias do início da imunização com COL V, quando comparado com os 
animais controle. Os animais submetidos à indução de tolerância nasal expressaram uma quantidade significativamente menor destes colágenos.

Um fato muito interessante foi a confirmação da imunomarcação anormal para o colágeno tipo $\mathrm{V}$, observado nos animais imunizados. De forma surpreendente, houve reversão desta anomalia estrutural protéica nos animais que receberam indução de tolerância nasal com $\mathrm{COL} V$, que voltaram a exibir padrão habitual de fibras finas de colágeno $\mathrm{V}$, depositados na membrana basal e na derme profunda. As coelhas imunizadas apenas com colágeno tipo $\mathrm{V}$ e adjuvante de Freund e as submetidas à indução de tolerância nasal com o COL V, por dois meses, apresentaram aspectos morfológicos da pele similares aos de animais normais.

Embora não tenha sido nosso objetivo principal, realizamos a reação de TUNEL, para analisar a apoptose de células na pele dos animais com ES experimental, antes e após a indução de tolerância nasal. Verificamos que os animais com ES, não submetidos à indução de tolerância nasal com colágeno tipo $\mathrm{V}$, apresentavam grande número de células em apoptose; por outro lado, após o tratamento, estas células praticamente não foram identificadas. Não foi possível, nestes experimentos, definir quais os tipos celulares que se apresentavam apoptóticos, sendo necessários outros ensaios mais específicos.

Nossos resultados confirmaram que animais imunizados expressaram FAN e anticorpos anticolágeno dos tipos III e IV, evidenciando o desenvolvimento de autoimunidade neste modelo experimental. Presença de anticorpos anticolágeno dos tipos IV e $\mathrm{V}$ foram previamente descritos em 
pacientes com ES (Mackel et al., 1982; Riente et al., 1995), sugerindo haver lesão na membrana basal nesta enfermidade. Postulamos que a agressão endotelial seria um aspecto comum, presente tanto nos pacientes com esclerodermia, como nos animais do presente modelo experimental. Esta agressão, quando prolongada, poderia causar lesão da membrana basal, promovendo a exposição de colágenos dos tipos IV e V, localizados na membrana basal, desencadeando a formação de anticorpos contra estes constituintes.

Aparentemente, a indução de tolerância nasal não interferiu na produção de autoanticorpos pelos animais imunizados com COL V, talvez devido ao curto período de seguimento. Normalmente, na prática clínica, os títulos de diferentes autoanticorpos, exceto em raras condições, como a detecção de anti-DNA, não se modificam em curto prazo, não refletindo no prognóstico clínico.

Baseados nos resultados apresentados, acreditamos que o colágeno tipo $\mathrm{V}$ possa ser um dos antígenos específicos desencadeantes da resposta celular T dependente presente na ES. É possível que diferentes fatores exógenos, como vírus, substâncias tóxicas ou moléculas com tropismo para células endoteliais, causem dano vascular com exposição de antígenos ocultos, como fragmentos do colágeno $\mathrm{V}$, iniciando todo o processo patogênico observado tanto nos pacientes, como neste modelo experimental. Esta agressão, em teoria, deveria ser prolongada o suficiente para desencadear processo inflamatório tecidual, originando a produção de metaloproteinases, responsáveis pela degradação e exposição de diferentes 
componentes da matriz extracelular, gerando antígenos anteriormente ocultos. Este processo torna-se autoimune, à medida que estes neoantigenos desencadeiam a formação de autoanticorpos, contribuindo na perpetuação do dano tecidual.

De fato, esta teoria justifica o surgimento de casos clínicos de ES após infecção prolongada por citomegalovirus, uso de substâncias tóxicas (bleomicina, cloreto de vinil); doença de enxerto versus hospedeiro; transplante de células imunes entre indivíduos diferentes, pois são condições que podem danificar o endotélio, por ação direta, ou gerando imunecomplexos que vão aderir à parede vascular.

Outros aspectos importantes relacionados a este modelo experimental referem-se ao aparecimento tardio de anticorpos e síntese quantitativamente maior de colágeno do tipo $\mathrm{V}$, estruturalmente defeituosa pelos fibroblastos. Este último achado foi igualmente demonstrado em pacientes com ES, tanto em tecidos, como em culturas de fibroblastos (Souza et al., 2005). Como citado anteriormente, alguns autoanticorpos como os anticolágenos tipos IV e V (quando da resposta secundária ao surgimento do neoantígeno), provavelmente participem da patogênese da doença, contribuindo para perpetuar a vasculite. Porém, não conseguimos explicar por que estes animais desenvolvem autoanticorpos contra constituintes citoplasmáticos. Seria porque há síntese de proteínas aberrantes neste modelo experimental?

Vários pesquisadores descreveram anormalidades na sinalização do TGF- $\beta$ na ES. Recentemente, modelos de ES têm sido desenvolvidos em 
linhagens de camundongos com deficiência na sinalização do TGF- $\beta$, que resultaram em modificações genéticas ou deleção dos principais mediadores de transdução do TGF- $\beta$. Estes achados valorizaram o encontro aumentado de expressão do COL $V$ de estrutura anormal em nosso modelo animal e em pacientes com esclerodermia. Além do mais, visto que o COL V participa no processo de fibrilogênese e contribui para a manutenção da histoarquitetura da matriz extracelular, esta anormalidade poderia explicar o aspecto característico da pele visto nos pacientes com ES. Em outras palavras, o desarranjo tecidual e a diminuição da função, observados em pacientes com ES, refletiriam a síntese de um colágeno $\mathrm{V}$, estruturalmente anômalo. Surpreendentemente, animais imunizados e submetidos à indução de tolerância nasal voltaram a expressar moléculas de COL V morfologicamente normais, revelando que o fenótipo anormal pode ser revertido. Este é um aspecto particularmente importante e original, pois abre perspectivas na reversão de fibrose observada na ES, se a patogênese em humanos for semelhante ao descrito neste modelo experimental.

Acreditamos que existam diferentes mecanismos patogênicos envolvidos no desencadeamento de alterações similares à esclerodermia, exibidas neste modelo experimental, induzido por COL V. Demonstrou-se a participação do COL V na indução de apoptose e na regulação da expressão de genes apoptóticos e de resposta ao estresse em linhagem de células neoplásicas no câncer de mama (Pucci- Minafra et al., 2000; Luparello et al., 2003; Luparello et al., 2005). Não sabemos se no nosso modelo experimental de ES o colágeno $V$ teria essas funções. Porém, ao 
demonstrarmos que as alterações morfológicas ocorrem precocemente neste modelo, em questão de dias (Oliveira, 2005), é um forte indício de que a ativação ou apoptose de células endoteliais, provavelmente promovido por fragmentos do colágeno tipo $\mathrm{V}$ humano inoculado em coelhas, tenha sido o evento primário que desencadeou a doença. É também plausível que tenha havido prévio processamento da macromolécula do colágeno $V$, inoculada via peritonial do animal, pelo sistema reticulo-endotelial, em fragmentos menores, antes de adentrar no sistema circulatório.

Admitimos que as células endoteliais ativadas ou em apoptose secretam mediadores proinflamatórios, moléculas de adesão, citocinas e fatores de crescimento, auxiliando na infiltração de células inflamatórias do sangue para o espaço extracelular, assim como substâncias vasoativas, como a endotelina. Em concordância com a nossa hipótese, recentemente, foi demonstrado que a apoptose de células endoteliais desencadeia a liberação de uma série de mediadores fibrogênicos (Laplante et al., 2005). Em conseqüência disto, os fibroblastos adquirem um estado de resistência à apoptose, além de aumentar a diferenciação dos mesmos em miofibroblastos. Estas últimas células produzem uma grande quantidade de colágeno, assim como outras proteínas da matriz extracelular, culminando, com o passar do tempo, em fibrose (Laplante et al., 2005).

É possível também que fragmentos de COL V (neoantígeno), gerados durante o processo inflamatório, possam desencadear resposta celular $\mathrm{T}$ dependente, levando à produção de células Th2, as quais secretariam citocinas profibróticas, como IL-4, IL-5 e IL-13, numa tentativa de reparar a 
lesão tecidual. Adicionalmente, a IL-4 promoveria a síntese de TGF- $\beta$ por ativação de células mononucleares, endoteliais e fibroblastos (Ong et al., 1998; Ong et al., 1999; Kodera et al., 2002; McGaha e Bona, 2002). O TGF$\beta$, ao se ligar a receptores localizados nos fibroblastos, ativaria os fatores de transcrição ("smads"), aumentando a síntese de componentes da matriz extracelular (MEC) (Nabel et al., 1993; Varga e Jimenez, 1995). Além do mais, o TGF- $\beta$ estimularia também os monócitos a produzirem o fator de crescimento derivado de plaquetas (PDGF), o qual é outra citocina profibrótica. No nosso trabalho, encontramos alta expressão de TGF- $\beta$ e PDGF em animais imunizados com COL V. Demonstramos que os animais tolerados por via nasal apresentaram expressão diminuída de ambas as citocinas, associadas com depósito menor de colágeno na MEC.

Sugerimos que o decréscimo na síntese dos colágenos I, III e V, além das citocinas TGF- $\beta$ e PDGF na pele dos animais tratados com indução de tolerância nasal com COL $V$, seriam conseqüências da participação de células regs $\operatorname{Tr} 1$, que produzem grandes quantidades de IL-10, inibindo a resposta autoimune T dependente (Jonuleit e Schmitt, 2003; Taylor et al., 2006). Além disso, trabalhos demonstram que as células Tr1 controlam a ativação de células T "in vitro" e "in vivo", suprimindo respostas imunes medidas por linfócitos Th1 e Th2 para patógenos, tumores e aloantígenos (Jonuleit e Schmitt, 2003).

Estudos prévios demonstram que a expressão de RNA mensageiro para colágeno I e fibronectina de fibroblastos de pele de pacientes com esclerodermia estão inibidos pela ação da IL-10 (Yamamoto et al., 2001). 
Comprovou-se também que a IL-10 diminuiu a expressão do RNA mensageiro para colágeno I e fibronectina, estimulado pelo TGF- $\beta$, sugerindo um papel da IL-10 na regulação do remodelamento tecidual (Yamamoto et al., 2001). Embora não tenha sido o objetivo deste trabalho verificar a expressão de IL-10 em animais tolerados, é possível que esta citocina tenha uma ação na diminuição do remodelamento de colágeno após indução de tolerância.

A esclerodermia é uma doença extremamente complexa em todos os aspectos, incluindo patogênese, manifestações clínicas e terapêuticas. Em geral, frente a pacientes com ES grave, os médicos sentem grande desapontamento, pois dispõem de poucos recursos terapêuticos capazes de reverter o prognóstico ruim desta enfermidade.

Esperamos que este conceito mude com descobertas de novas pesquisas em modelos experimentais ou em pacientes com ES. Apresentamos resultados que mostram que a esclerodermia pode ser vista como uma enfermidade de cunho dinâmico e não imutável, passível de abordagem terapêutica. Se pesquisas futuras confirmarem que a patogênese da esclerodermia em humanos é semelhante ao observado neste modelo experimental, abre-se uma enorme perspectiva na identificação do distúrbio patogênico inicial, permitindo desconectar vias que conduzem à perpetuação dos processos inflamatórios e imunológicos e que levam à falência de múltiplos órgãos.

Concluímos que este modelo experimental de ES, o qual apresenta muitas semelhanças com a esclerodermia humana, sugere ser essa uma 
doença T dependente para um antígeno específico, e que o colágeno do tipo V seja um dos envolvidos, pois demonstramos que a indução da tolerância nasal com esta proteína reverteu alterações histológicas observadas neste modelo. Assim, consideramos esta modalidade terapêutica altamente promissora no controle desta grave enfermidade reumatológica. 


\section{VI - CONCLUSÕES}

Concluímos que com a indução da tolerância nasal, através da administração diária de colágeno tipo V, durante 60 dias, iniciada 150 dias após a indução de esclerodermia experimental em coelhos, houve:

- Diminuição do conteúdo total de colágeno na pele dos animais tolerados.

- Diminuição do remodelamento de colágenos I, III e $\mathrm{V}$ na pele dos animais tolerados.

- Diminuição da expressão de citocinas fibrogênicas (TGF- $\beta$ e PDGF) na pele dos animais tolerados.

- Diminuição de apoptose de células na pele dos animais tolerados.

- Não houve diminuição significativa na freqüência de auto-anticorpos (anti-colágeno III e IV e FAN) no soro dos animais tolerados no período estudado. 


\section{REFERÊNCIAS BIBLIOGRÁFICAS}

Abbas AK, Pober JS, Lichtman AH. Cellular and Molecular Immunology. $3^{\text {rd }}$ ed. Philadelphia, Pensylvania: Saunders Company; 1997.

Abraham DJ, Varga J. Scleroderma: from cell and molecular mechanisms to disease models. Autoimmunity Spec Iss. 2005; 26(11):587-95.

Adachi E, Hayashi T. In vitro formation of hybrid fibrils of type $V$ collagen and type I collagen. Limited growth of type I collagen into thick fibrils by type $\mathrm{V}$ collagen. Connect Tissue Res. 1986; 14(4):257-66.

Akbari O, Dekruyff RH, Umetsu DT. Pulmonary dentritic cells producing IL10 mediate tolerance induced by respiratory expore to antigen. Nat Immun. $2001 ; 2: 725-731$.

Andrikopoulos K, Liu X, Keene DR, Jaenisch R, Ramirez F. Targeted mutation in the col5a2 gene reveals a regulatory role for type $\mathrm{V}$ collagen during matrix assembly. Nat Genet. 1995; 9(1):31-6. 
Arnett FC, Reveille JD, Goldstein R, Pollard KM, Leaird K, Smith EA, et al. Autoantibodies to fibrillarin in systemic sclerosis (scleroderma): an immunogenetic, serologic, and clinical analysis. Arthritis Rheum. 1996; 39:1151-60.

Arnett FC. HLA and autoimmunity in scleroderma (systemic sclerosis). Inter Rev Immunol. 1995; 12:107-28.

Artlett CM, Cox LA, Jimenez SA Detection of cellular microchimerism of male origin in systemic sclerosis patients by polymerase chain reaction analysis of HLA-Cw antigens. Arthritis Rheum. 2000; 43: 1062-1066.

Bai X-F, Link $H$. Nasal tolerance induction as a potencial means of immunotherapy for autoimmune diseases: implications for clinical medicine. Clin Exp Allergy. 2000; 30:1688-1696.

Bárdos T, Czipri M, Vermes C, Zhang J, Mikecz K, Glant TT. Continuous nasal administration of antigen is critical to maintain tolerance in adoptively transferred autoimmune arthritis in SCID mice. Clin Exp Immunol. 2002; 129 : $224-231$.

Bell SA, Faust H, Mittermuller J, Kolb HJ, Meurer M. Specificity of antinuclear antibodies in scleroderma-like graft versus host disease: clinical correlation 
and histocompatibility locus antigen association. $\mathrm{Br} \mathrm{J}$ Dermatol. 1996; 134:848-54.

Bellanti JA. Literature review: The best new articles in the specialty of allergy, asthma, and immunology, 2004-2005. Allergy Asthma Proc. 2006; 27(3):186196.

Bezerra MC, Teodoro WR, Oliveira CC, Velosa APP, Ogido LTI, Gauditano G, Parra ER, Capelozzi VL, Yoshinari NH. Scleroderma-like remodelling induced by type V collagen. Arch Dermatol Res. 2006; 298(2):51-7.

Bharat A, Fields RC, Steward N, Trulock EP, Patterson GA, Mohanakumar T. CD4+25+ regulatory $T$ cells limit Th1-autoimmunity by inducing IL-10 producing $\mathrm{T}$ cells following human lung transplantation. Am J Transplant. 2006; 6(8):1799-808.

Birk DE, Fitch JM, Babiarz JP, Doane KJ, Linsenmayer TF. Collagen fibrillogenesis in vitro: interaction of types I and $V$ collagen regulates fibril diameter. J Cell Sci. 1990; 95:649-657.

Birk DE, Fitch JM, Linsenmayer TF. Organization of collagen types I and V in the embryonic chicken cornea. Investig Ophthalmol Vis Sci. 1986; 27:14701477. 
Birk DE. Type $\mathrm{V}$ collagen: heterotypic type $\mathrm{I} / \mathrm{V}$ collagen interactions in the regulation of fibril assembly. Micron. 2001; 32:223-237.

Bitar DM, Whitacre CC. Suppression of experimental autoimmune encephalomyelitis by the oral administration of myelin basic protein. Cell Immunol. 1988; 112:364-70.

Bogatkevich GS, Tourkina E, Silver RM, Ludwicka-Bradley A. Thrombin differentiates normal lung fibroblasts to a myofibroblast phenotype via the proteolytically activated receptor-1 and a protein kinase C-dependent pathway. J Biol Chem. 2001; 276:45184-45192.

Bordon A, Dueymes M, Levy Y, Jamin C, Leroy JP, Piette JC, Shoenfeld Y, Youinou PY. The binding of some human antiendothelial cell antibodies induces endothelial cell apoptosis. J Clin Invest. 1998; 101:2029.

Bueno V, Pacheco-Silva A. Tolerância oral: uma nova perspectiva no tratamento de doenças autoimunes. Rev Assoc Med Bras. 1999; 45(1): 7985.

Buer J, Lanoue A, Franzke A, Garcia C, von Boehmer H, Sarukhan A. Interleukin 10 secretion and impaired effector function of major histocompatibility complex class II-restricted T cells anergized in vivo. J Exp Med. 1998; 187(2):177-183. 
Chanut-Delalande H, Bonod-Bidaud C, Cogne S, Malbouyres M,Ramirez F, Fichard A, Ruggiero F. Development of a functional skin matrix requires deposition of collagen V heterotrimers. Molec Cell Biol. 2004; 24(13): 60496057.

Chen W, Jin W, Cook M, Weiner HL, Wahl SM. Oral delivery of group A streptococcal cell walls augments circulating TGF-beta and suppresses streptococcal cell wall arthritis. J Immunol. 1998; 161:6297-6304.

Christner PJ et al. Increased numbers of microchimeric cells of fetal origin are associated with dermal fibrosis in mice following injection of vinyl chloride. Arthritis Rheum. 2000; 43:2598-2605.

Christner PJ, Peters D, Hawkins LD, Siracusa SA. The tight skin 2 mouse: an animal model of scleroderma displaying cutaneous fibrosis and mononuclear cell infiltration. Arthritis Rheum. 1995; 38:1791-1798.

Clark SH Animal models in SSc. Rheumatol Rep. 2005; 7:150-155.

Clements PJ, Lachenbruch PA, Sterz M, Danovitch G, Hawkins R, Ippoliti A, et al. Cyclosporine in systemic sclerosis: results of a forty-eight-week open safety study in ten patients. Arthritis Rheum. 1993; 36:75-83. 
Cohen I, Young DB. Autoimmunity, microbial immunity and the immunological homunculus, Immunol Today. 1991; 12:105-110.

Czerkinsky C F, Anjuere JR, McGhee A, George-Chandy J, Holmgren M-P et al. Mucosal immunity and tolerance: relevance to vaccine development, Immunol Rev. 1999; 170:197-222.

Denton $\mathrm{CP}$ et al. Activation of key profibrotic mechanisms in transgenic fibroblasts expressing kinase-deficient type II transforming growth factor- $\beta$ receptor (T $\beta$ RIIIk). J Biol Chem. 2005; 280:16053-65.

Denton CP, Abraham DJ. Transgenic analysis of scleroderma: understanding key pathogenic events in vivo. Autoimmun Rev. 2004; 3(4):285-93.

Diot E, Giraudeau B, Diot P et al. Is anti-topoisomerase I a serum marker of pulmonary involvement in systemic sclerosis? Chest. 1999; 116:715-720.

Fakhoury H, Hillarby MC, Weiss JB. Increased gelatinase activity in systemic sclerosis dermal fibroblast cultures with unaltered gelatinase A mRNA expression. J Dermatol Sci. 2002; 29:62-69.

Falanga V, Gerhardt CO, Dasch JR, Takehara K, Ksander GA. Skin distribution and differential expression of transforming growth factor $\beta 1$ and ß2. J Dermatol Sci. 1992; 3:131-6. 
Faria AM, Weiner HL. Oral tolerance: Therapeutic implications for autoimmune diseases. Clin Dev Immunol. 2006; 13(2):143-57.

Faria AMC, Weiner HL. Oral tolerance. Immunol Rev. 2005; 206:232-59.

Faria AMC, Weiner HL. Oral tolerance: mechanisms and therapeutic application. Adv Immunol. 1999; 73:153-265.

Ferri CG, Valentini F et al. Systemic sclerosis: demographic, clinical, and serologic features and survival in 1,012 Italian patients. Medicine (Baltimore) 2002; 81:139-153.

Fertin C, Nicolas JF, Gillery P, Kalis B, Banchereau J, Marquart FX. Interleukin-4 stimulates collagen synthesis by normal and scleroderma fibroblasts in dermal equivalents. Cell Mol Biol. 1991; 37:823-9.

Fitch JM, Gross J, Mayne R, Johnson-Wint B, Linsenmayer TF. Organization of collagen types $\mathrm{I}$ and $\mathrm{V}$ in the embryonic chicken cornea: monoclonal antibody studies. Proc Natl Acad Sci USA. 1984; 81:2791-2795.

Freire-de-Lima CG, Nascimento DO, Soares MB, Bozza PT, Castro-FariaNeto HC, de Mello FG, DosReis GA, Lopes MF. Uptake of apoptotic cells drives the growth of a pathogenic trypanosome in macrophages. Nature. 2000; 403(6766):199-203. 
Furt DE, Clements PJ, Graze P, Gale R, Robberts N. A syndrome resembling progressive systemic sclerosis after bone marrow transplantation: a model for scleroderma? Arthritis Rheum. 1979; 22:904-10.

Garcia G, Komogata Y, Slavin AJ, Maron R, Weiner HL. Suppression of Collagen-induced Arthritis by Oral or Nasal Administration of Type II Collagen. J Autoimmunity. 1999; 13:315-324.

Gaubitz M. Epidemiology of connective tissue disorders. Rheumatol. 2006; 45:iii3-iii4.

Gay S, Martinez-Hernandez A, Rhodes RK, Miller EJ. The collagenous exocytoskeleton of smooth muscle cells. Collagen Relat Res. 1981; 1:377384.

Gelse K, Poschl E, Aigner T. Collagens--structure, function, and biosynthesis. Adv Drug Deliv Rev. 2003; 55(12):1531-46.

Gentiletti J, McCloskey LJ, Artlett CM, Peters J, Jimenez SA, Christner PJ. Demonstration of autoimmunity in the tight skin-2 mouse: a model for scleroderma. J Immunol. 2005; 175(4):2418-26.

Haque MA, Myzobuchi T, Yasufuku K, Fujisawa T, Brutkiewiez RR, Zeng Y, Woods K, Smith GN, Cummings OW, Heidler KM, Wilkes DS. Evidence for 
immune responses to a self antigen in lung transplantation: role of type $\mathrm{V}$ collagen-specific $\mathrm{T}$ cells in the pathogenesis of lung allograft rejection. $\mathrm{J}$ Immunol. 2002; 69:1542-49.

Higuchi K, Kweon MN, Fujihashi K, McGhee JR, Kiyono H. Comparison of nasal and oral tolerance for the prevention of collagen induced murine arthritis. J Rheumatol. 2000; 27:1038-44.

Hirahara K, Hisatsune T, Nishijima K, Kato H, Shiho O, Kaminogawa S. CD4+ $\mathrm{T}$ cells anergized by high dose feeding establish oral tolerance to antibody responses when transferred in SCID and nude mice. J Immunol. $1995 ; 154: 6238-6245$.

Hoyne GF, Askonas BA, Hetzel C, Thomas WR, Lamb JR. Regulation of house dust mite responses by intranasally administered peptide: transient activation of CD4+ T cells precedes the development of tolerance in vivo. Int Immunol. 1996; 8(3):335-42.

Hoyne GF, Lamb JR. Regulation of $\mathrm{T}$ cell function in mucosal tolerance. Immunol Cell Biol. 1997; 75(2):197-201.

Jimenez SA, Batuman O. Immunopathogenesis of systemic sclerosis: possible role of retroviruses. Autoimmunity. 1993; 16:225-33. 
Jonuleit H, Schmitt E. The Regulatory $T$ cell family: Distinct subsets and their interrelations. J Immunol. 2003; 171(12):6323-7.

Jun JB, Keuchle M, Harlan JM, Elkon KB. Fibroblast and endothelial apoptosis in systemic sclerosis. Curr Opin Rheumatol. 2003; 15:756.

Khare SD, Krco CJ, Griffiths MM, Luthra HS, David CS. Oral administration of an immunodominant human collagen peptide modulates collagen-induced arthritis. J Immunol. 1995; 155:3653-3659.

Kodera T, McGaha TL, Phelps R, Paul WE, Bona CA. Disrupting the IL-4 gene rescues mice homozygous for the tight-skin mutation from embryonic death and diminishes TGF-beta production by fibroblasts. Proc Natl Acad Sci U S A. 2002; 99(6):3800-5.

Kuwana M, Kaburaki J, Okano Y, Inako H, Tsuji K. The HLA_DR and DQ genes control the autoimmune response to DNA topoisomerase I in systemic sclerosis (scleroderma) J Clin Invest. 1993; 92:1296-301.

Kuwana M, Mesdger TA, Wright TM. T and B collaboration is essential for the autoantibody response to DNA topoisomerase I in systemic sclerosis. J Immunol. 1995; 155:2703-14.

Lanoue A, Bona C, von Boehmer H, Sarukhan A. Conditions that induce tolerance in mature CD4+ T cells. J Exp Med. 1997; 185(3):405-14. 
Laplante P, Raymond MA, Gagnon G, Vigneault N, Sasseville AM, Langelier Y, Bernard M, Raymond Y, Hebert MJ. Novel fibrogenic pathways are activated in response to endothelial apoptosis: implications in the pathophysiology of systemic sclerosis. J Immunol. 2005; 174(9):5740-9.

Lider O, Santos LMB, Lee CSY, Higgins PJ, Weiner HL. Suppression of experimental autoimmune encephalomyelitis by oral administration of myelin basic protein. II. Suppression of disease and in vitro immune responses is mediated by antigen-specific CD81 T lymphocytes. J Immunol. 1989; 142:748-52.

Linsenmayer TF, Gibney E, Igoe F, Gordon MK, Fitch JM, Fessler LI, Birk DE. Type $V$ collagen: molecular structure and fibrillar organization of the chicken alpha $1(\mathrm{~V}) \mathrm{NH}$ 2-terminal domain, a putative regulator of corneal fibrillogenesis. J Cell Biol. 1993; 121:1181-1189.

Lombardi G, et al. Antigen presentation by interferon-gamma-treated thyroid follicular cells inhibits interleukin-2 (IL-2) and supports IL-4 production by B7dependent human T cells. Eur J Immunol. 1997; 27:62-71.

Luparello C, David F, Campisi G, Sirchia R. T47-D cells and type V collagen: A model for study of apoptotic gene expression by breast cancer cells. Biol Chem. 2003; 381:965-975. 
Luparrelo C, Sirchia R. Type V collagen regulates the expression of apoptotic and stress renponse genes by breast cancer cells. J Cell Physiol. 2005; 202:411-421.

Mackel AM, DeLustro F, Harper FE, LeRoy EC. Antibodies to collagen in scleroderma. Arthritis Rheum. 1982; 25(5):522-31.

Mares DC, Heidler KM, Smith GN, Cummings OW, Harris ER, Foreman $\mathrm{BH}$, Wilkes DS. Type $\mathrm{V}$ collagen modulates alloantigen-induced pathology and immunology in the lung. Am J Respir Cell Mol Biol. 2000; 23:62-70.

Mayne R, Burgeson R. Structure and function of collagen types. In: Ulecham R (Ed) Biology of Extracellular Matrix. 20th ed. London: Academic Press; 1993. pp. 1-37.

McGaha T, Saito S, Phelps RG, Gordon R, Noben-Trauth N, Paul WE, et al. Lack of skin fibrosis in tight skin (TSK) mice with targeted mutation in the interleukin-4R $\alpha$ and transforming growth factor- $\beta$ genes. J Invest Dermatol. $2001 ; 116: 136-43$

McGaha TL, Bona CA. Role of profibrogenic cytokines secreted by T cells in fibrotic processes in scleroderma. Autoimmun Rev. 2002; 1(3):174-81.

Mckown KM, Carbone LD, Bustillo J, Seyer JM, Kang AH, Postlethwaite AE. Induction of immune tolerance to human type I collagen in patients with 
systemic sclerosis by oral administration of bovine type I collagen. Arthitis Rheum. 2000; 43(5):1054-61.

Mestecky J, Moldoveanu Z, Elson CO. Immune response versus mucosal tolerance to mucosally administered antigens. Vaccine. $2005 ; 23(15): 1800-3$.

Miller A, Al-Sabbagh A, Santos LMB, Das MP, Weiner HL. Epitopes of myelin basic protein that trigger TGF-b release after oral tolerization are distinct from encephalitogenic epitopes and mediate epitope-driven bystander suppression. J Immunol. 1993; 151:7307-15.

Miller A, Lider O, Roberts AB, Sporn MB, Weiner HL. Suppressor T cells generated by oral tolerization to myelin basic protein suppress both in vitro and in vivo immune responses by the release of transforming growth factor beta after antigen-specific triggering. Proc Natl Acad Sci U S A. 1992; $89(1): 421-5$.

Miller A, Lider O, Weiner HL. Antigen-driven bystander suppression after oral administration of antigens. J Exp Med. 1991; 174:791-798.

Miller EJ, Rhodes RK. Preparation and characterization of the different types of collagen. Methods Enzymol. 1982; $82 \mathrm{Pt} \mathrm{A:33-64.}$

Min SY, Hwang SY, Park KS, Lee JS, Lee KE, Kim KW, Jung YO, Koh HJ, Do JH, Kim H, Kim HY. Induction of IL-10-producing CD4+CD25+ T cells in 
animal model of collagen-induced arthritis by oral administration of type II collagen. Arthritis Res Ther. 2004; 6(3):R213-9.

Mizobuchi T, Yasufuku K, Zheng Y, Haque MA, Heidler KM, Woods K, Smith GN Jr, Cummings OW, Fujisawa T, Blum JS, Wilkes DS. Differential expression of Smad7 transcripts identifies the CD4+CD45RChigh regulatory $\mathrm{T}$ cells that mediate type $\mathrm{V}$ collagen-induced tolerance to lung allografts. $\mathrm{J}$ Immunol. 2003; 171(3):1140-7.

Modesti A, Kalebic T, Scarpa S, Togo S, Grotendorst G, Liotta LA, Triche TJ. Type $\mathrm{V}$ collagen in human amnion is a $12 \mathrm{~nm}$ fibrillar component of the pericellular interstitium. Eur J Cell Biol. 1984; 35:246-255.

Mouthon L, Pena-Lefebvre G P, Chanseaud Y, Tamby MC, Boissier MC, Guillevin L. Pathogénie de la sclérodermie: aspects immunologiques. Ann Med Int. 2002; 153:167-178.

Mowat $\mathrm{H}$, Weiner $\mathrm{H}$. Oral tolerance-physiological basis and clinical applications. In: Ogra PL, Mestecky J, Lamm ME, Strober W, Bienenstock J, McGhee JR. Editors, Mucosal Immunology, Academic Press, San Diego 1999. pp. 587-618.

Muryoi T, Kasturi KN, Kafina MJ, Cram DS, Harrison LC, Sasaki T, et al. Antitopoisomerase I monoclonal autoantibodies from scleroderma patients 
and tight skin mouse interact with similar epitopes. Revista. 1992; 175:11039.

Nabel EG, Shum L, Pompili VJ, Yang Z-Y. Direct transfer of transforming factor $\beta 1$ gene into arteries stimulates fibrocellular hyperplasia. Proc Natl Acad Sci USA. 1993; 90:10759-63.

Negi VS, Tripathy NK, Misra R. Nityanand S. Antiendothelial cell antibodies in scleroderma correlate with severe digital ischemia and pulmonary arterial hypertension. J Rheumatol. 1998; 25: 462-466.

Neidhart M, Kuchen S, Distler O, Bruhlman P, Michel BA, Gay R, et al. Increased serum levels of antibodies against human cytomegalovirus and prevalence of autoantibodies in systemic sclerosis. Arthritis Rheum. 1999; 42:389-92.

Niyibizi C, Fietzek PP, Rest VM. Human placenta type V collagens. Evidence for the existence of an $\alpha 1(\mathrm{~V}), \alpha 2(\mathrm{~V}), \alpha 3(\mathrm{~V})$. Col Mol 1984; 259:14170-174. Okano Y, Steen VD, Medsger TA. Autoantibody reactive with RNA olymerase III in systemic sclerosis. Ann Int Med. 1993; 119:1005-13.

Oliveira CC. Avaliação seqüencial da pele de coelhos imunizados com colágeno do tipo V. Monografia apresentada à Faculdade de Medicina da Universidade de São Paulo, para conclusão do programa de aprimoramento CAPES. São Paulo, 2005. p. 47. 
Ong C, Wong C, Roberts CR, Teh HS, Jirik FR. Anti-IL-4 treatment prevents dermal collagen deposition in the tight-skin mouse model of scleroderma. Eur J Immunol. 1998; 28(9):2619-29.

Ong CJ, Ip S, Teh SJ, Wong C, Jirik FR, Grusby MJ, Teh HS. Role for T helper 2 cells in mediating skin fibrosis in tight-skin mice. Cell Immunol. 1999; 196(1):60-8.

Overzet K, Gensler TJ, Kim SJ, Geiger ME, van Verooij WJ, Pollard KM, et al. Small nucleolar RNP scleroderma autoantigens associate with phosphorylated serine/arginine spicing factors during apoptosis. Arthritis Rheum. 2000; 43:1327-36.

Pandey JP, Leroy RC. Human cytomegalovirus and the vasculopathies of autoimmune diseases (especially scleroderma), allograft rejection, and coronary restenosis. Arthritis Rheum. 1998; 41:10-15.

Peters J, Ball ST. Tight skin 2 (Tsk2/+). Mouse News Lett. 74: 91 Pollard KM, Reimer G, Tan EM. Autoantibodies in scleroderma. Clin Exp Rheumatol. 1986; 3:S57-62.

Pollard KM, Reimer G, Tan EM. Autoantibodies in scleroderma. Clin Exp Rheumatol. 1989; 3:S57-62. 
Postlethwaite AE, Holness MA, Katai H, Raghow R. Human fibroblasts synthesize elevated levels of extracellular matrix proteins in response to interleukin 4. J Clin Invest. 1992; 90:1479-85.

Prakken BJ, Roord S, van Kooten PJS, Wagenaar JPA, van Eden W, Albani S, Wauben MHM. Inhibition of Adjuvant-Induced Arthritis by Interleukin-10Driven Regulatory Cells Induced Via Nasal Administration of a Peptide Analog of on Arthritis-Related Heat-Shock Protein 60 T Cell Epitope. Arthritis Rheum 2002; 46(7):1937-1946.

Prescott RJ, Freemont AJ, Jones CJP, Hoyland J, Fielding P. Sequential dermal microvascular and perivascular changes in the development of scleroderma. J Pathol. 1992; 166:255-63.

Pucci- Minafra I, Carela C, Cirincione R, Chimenti S, Minafra S, Luparello C. Type $\mathrm{V}$ collagen induces apoptosis of $8701-\mathrm{BC}$ breast cancer cells and enhaces M clapian expression. Breast Cancer Res 2000; 2:E008.

Querfeld C, Eckes B, Huerkamp C, Krieg T, Sollberg S. Expression of TGFbeta 1 , -beta 2 e -beta 3 in localized and systemic scleroderma. J Dermatol Sci. 1999; 21:13-22. 
Rattner JB, Ress J, Arnett Fc, Reveille JD, Goldstein R, Fritzler MJ. The centromere kinesis-like protein, CENP-E: an autoantigen in systemc sclerosis. Arthritis Rheum. 1996; 39:1355-61.

Riente L, Marchini B, Dolcher MP, Puccetti A, Bombardieri S, Migliorini P. Anti-collagen antibodies in systemic sclerosis and primary Raynaud's phenomenon. Clin Exp Immunol. 1995; 102(2):354-9.

Ruzek MC et al. A modified model of graft-versus-host-induced systemic sclerosis (scleroderma) exhibits all major aspects of the human disease, Arthritis Rheum. 2004; 50:1319-1331.

Saito E et al. CD19-dependent B lymphocyte signaling thresholds influence skin fibrosis and autoimmunity in the tight-skin mouse. J Clin Invest. 2002; 109:1453-62.

Sakkas LI, Platsoucas CD. Is systemic sclerosis an antigen-driven $\mathrm{T}$ cell disease? Arthritis Rheum. 2004; 50(6):1721-1733.

Sakkas LI, Xu B, Artlett CM, Lu S, Jimenez S A Platsoucas CD. Oligoclonal T Cell Expansion in the Skin of Patients with Systemic Sclerosis. J Immunol. 2002; 168:3649-3659. 
Sato S, Nagaoka T, Hasegawa M, Tamatani T, Nakanishi T, Takigawa M, et al. Serum levels of connective tissue growth factor are elevated in patients with systemic sclerosis: association with extent of skin sclerosis and severity of pulmonary fibrosis. J Rheumatol. 2000; 27:149-54.

Seder RA, Marth T, Sieve MC, Strober W, Letterio JJ, Roberts AB, et al. Factors involved in the differentiation of TGF- $\beta$ producing cells from naive CD4+ T cells: IL-4 and IFN-Y have opposing effects, while TGF- $\beta$ positively regulates its own production. J Immunol. 1998; 160: 5719-28.

Segev F, Heon E, Cole WG, Wenstrup RJ, Young F, Slomovic AR, Rootman DS, Whitaker-Menezes D, Chervoneva I, Birk DE. Structural abnormalities of the cornea and lid resulting from collagen V mutations. Invest Ophthalmol Vis Sci. 2006; 47(2):565-73.

Sgonc, R., M. S. Gruschwitz, H. Dietrich, H. Recheis, M. E. Gershwin, G. Wick. Endothelial cell apoptosis is a primary pathogenetic event underlying skin lesions in avian and human scleroderma. J Clin Invest. 1996; 98(3):78592.

Sgonc, R.The vascular perspective of systemic sclerosis: of chickens, mice and men. Int. Arch. Allergy Immunol. 1999; 120:169-176.

Shapiro SD, Endicott SK, Province MA, Pierce JA, Campbell EJ. Marked longevity of human lung parenchymal elastic fibers deduced from prevalence 
of D-aspartate and nuclear weapons-related radiocarbon. J Clin Invest. 1991; 87: 1828-1834.

Shi-Wen X, Pennington D, Holmes A, Leask A, Bradham D, Beauchamp JR, et al. Autocrine overexpression of CTGF maintains fibrosis: RDA analysis of fibrosis genes in systemic sclerosis. Exp Cell Res. 2000; 259:213-24.

Siimes MA, Johansson E, Rapola J Scleroderma-like graft-versus-host disease as a late consequence of bone-marrow grafting. Lancet. 1977; 2: $831-2$

Souza RBC, Borges CTL, Capelozzi VL, Carrasco S, Velosa APP, Teodoro WR, Goldenstein-Schainberg C, Yoshinari NH: Abnormal Collagen Type V Deposition in Lung Fibroblast is Correlated with a Worse Pulmonary Capacity in Scleroderma (SSc). Arthritis Rheum. 2005; 52(9):s177.

SPSS Statistical software (2002) Version 10.0. SPSS Inc, Chicago.

Steen VD, Powell DL, Medsger TA Jr. Clinical correlations and prognosis based on serum autoantibodies in patients with systemic sclerosis. Arthritis Rheum. 1988; 31:196-203. 
Sumpter TL, Wilkes DS. Role of autoimmunity in organ allograft rejection: a focus on immunity to type $V$ collagen in the pathogenesis of lung transplant rejection. Am J Physiol Lung Cell Mol Physiol. 2004; 286(6):L1129-39.

Taams LS, et al. Anergic T cells actively suppress $T$ cell responses via the antigenpresenting cell. Eur J Immunol. 1998; 28:2902-2912.

Takahashi T, et al. Immunologic self-tolerance maintained by CD25+ CD4+ naturally anergic and suppressive T cells: induction of autoimmune disease by breaking their anergic/suppressivestate. Int Immunol. 1998; 10:19691980.

Tamby MC, Chamseaud Y, Guillevin L, Mouthon L. New insights into the pathogenesis of systemic sclerosis. Autoimmunity Rev. 2003; 2:152-157.

Taylor A, Verhagen J, Blaser K, Akdis M, Akdis CA. Mechanisms of immune suppression by interleukin-10 and transforming growth factor- $\beta$ : the role of $T$ regulatory cells. Immunol. 2006; 117: 433-442.

Teodoro WR, Miron BG, Ogido LT, Velosa APP, Abatepaulo F, Capelozzi VL, Yoshinari $\mathrm{NH}$. Synovial remodelling process induced by type $\mathrm{V}$ collagen immunization in rabbits. Pathol Res Pract. 2003; 199:605-612. 
Teodoro WR, Velosa APP, Witzel SS, Garippo AL, Farhat C, Parra ER, Sonohara S, Capelozzi VL, Yoshinari NH. Architectural remodelling in lungs of rabbits induced by type $\mathrm{V}$ collagen immunization: a preliminary morphologic model to study diffuse connective tissue diseases. Pathol Res Pract. 2004; 200:681-91.

Thompson SJ, et al. Prevention of pristaneinduced arthritis by the oral administration of type II collagen. Immunol. 1993; 79:152-157.

Thorbecke GJ, Schwarcz R, Leu J, Huang C, Simmons WJ. Modulation by cytokines of induction of oral tolerance to type II collagen. Arthritis Rheum. 1999; 42(1):110-8.

Tsuji NM, Mizumachi K, Kurisaki J. Antigen-specific, CD4+ CD25+ regulatory T cell clones induced in Peyer's patches. Int Immunol. 2003; 15:525-534.

Unger WWJ, Hauet-Broere F, Jansen W, van Berkel LA, Kraal G, Samsom JN. Early Events in Peripheral Regulatory T Cell Induction via the Nasal Mucosa. J Immunol. 2003; 171(9):4592-603.

Unger WWJ, Jansen W, Wolvers DAW, van Halteren AGS, Kraal G, Samsom JN. Nasal tolerance induces antigen-specific $\mathrm{CD} 4^{+} \mathrm{CD} 25^{-}$regulatory $\mathrm{T}$ cells that can transfer their regulatory capacity to naive $\mathrm{CD} 4^{+} \mathrm{T}$ cells. Jap Soc Immunol. 2003; 15 (6):731-739. 
Van Halteren AGS, Van der Cammen MJF, Cooper D, Savelkoul HFJ, Kraal G, Holt PG. Regulation of antigen-specific lgE, IgG1 and mast cell responses to ingested allergen by mucosal tolerance induction. J. Immunol. 1997; 59(6):3009-15.

Varga $\mathrm{J}$ and Jimenez SA. Modulation of collagen gene expression: its relation to fibrosis in systemic sclerosis and other disorders. Ann Intern Med. $1995 ; 122: 60-2$.

Vilas AP, Veiga MZ, Abecasis P. Esclerose sistémica - perspectivas actuais. Med Int. 2002; 9(2):111-120.

Weiner H L. Oral tolerance: immune mechanisms and the generation of Th3type TGF-beta-secreting regulatory cells. Microbes Infect. 2001; 3(11):94754.

Whitacre CC, Gienapp IE, Orosz CG, Bitar DM. Oral tolerance in experimental autoimmune encephalomyelitis. III. Evidence for clonal anergy. J Immunol. 1991; 147:2155-2163.

Wigley FM. Systemic sclerosis. In: Klippel JH; Dieppe PA (ed). Rheumatology. $2^{\text {nd }}$ ed. London Philadelphia: Mosby; 1999. pp. 7.9.1-7.13.11. 
Wilkes DS. The role of autoimmunity in the pathogenesis of lung allograft rejection. Arch Immunol Ther Exp (Warsz). 2003; 51(4):227-30.

Wolfraim LA. Treating autoimmune diseases through restoration of antigenspecific tolerance. Arch Immunol Ther Exp. 2006; 54:1-13.

Wolvers DAW, Roo, CJJ.C, Mebius RE, van der Cammem MJF, Tirion F, Miltenburg AMM, Kraal G. Intranasally Induced Immunological Tolerance Is Determined by Characteristics of the Draining Lymph Nodes: Studies with OVA and Human Cartilage gp-39. J Immunol. 1999; 162:1994-1998.

Wolvers DAW, Van der Cammen MJF, Kraal G. Mucosal tolerance is associated with, but independent of, upregulation of Th2 responses. Immunol. 1997; 92:328.

Yamakage A, Kikuchi K, Smith EA, LeRoy EC, Trojanowska M. Selective upregulation of platelet-derived growth factor $\alpha$ receptors by transforming growth factor $\beta$ in scleroderma fibroblasts. J Exp Med. 1992; 175:1227-34.

Yamamoto T, Eckes B, Krieg T. (2001) Effect of interleukin-10 on the gene expression of type I collagen, fobronectin, and decorin in human skin fibroblasts: differential regulation by transforming growth factor- $\beta$ and Monocyte chemoattractant protein-1. Biochem Biophysic Res Comm 281: 200-205. 
Yamamoto T, Nisshioka K. Cellular and molecular mechanisms of bleomycininduced murine SSc: current update and future perspective. Exp Dermatol. $2005 ; 14: 81-95$.

Yasufuku K, Heidler KM, O’Donell PW, Cummings OW. Foreman BH, Fujisawa T, Wilkes DS. Oral tolerance induction by type $\mathrm{V}$ collagen Downregulates lung allograft. Am J Respir Cell Mol Biol. 2001; 25(1):26-34.

Yasufuku K, Heidler KM, Woods KA, Smith GN Jr, Cummings OW, Fujisawa T, Wilkes DS Prevention of bronchiolitis obliterans in rat lung allografts by type V collagen-induced oral tolerance. Transplant. 2002; 73:500-505.

Yoshida S, Haque A, Mizobuchi T, Iwata T, Chiyo M, Webb TJ, Baldridge LA, Heidler KM, Cummings OW, Fujisawa T, Blum JS, Brand DD, Wilkes DS. Anti-type $\mathrm{V}$ collagen lymphocytes that express IL-17 and IL-23 induce rejection pathology in fresh and well-healed lung transplants. Am J Transplant. 2006; 6(4):724-35.

Yoshinari NH, Callado MR, Velosa APP, Viana VTS, GoldeinsteinSchainberg C, Carrasco S, Bezerra MC, Ogido LT, Oliveira CC, Capelozzi VL, Teodoro WR. Experimental Model of Scleroderma Induced in Rabbits. Arthritis Rheum 2005; 52(9):s369.

Yoshinari NH, Teodoro WR, Ogido LTI, Velosa APP, Prizon CP, Miron B, Bissoli JCC, Cuentas ERP, Capelozzi VL. Modelo experimental de doenças 
difusas do tecido conjuntivo (DDTC) induzido por colágeno do tipo V. Rev Bras Reumatol. 2002; 42:295-305.

Yoshino S MA, Yoshino S, Inada S, Nomaguchi H, Tokunaga O, Kohashi O. Suppression of adjuvant arthritis in rats by induction of oral tolerance to mycobacterial 65-kDa heat shock protein. Eur J Immunol. 1996; 26:26502656.

Yoshino S. Antigen-induced arthritis in rats is suppressed by the inducing antigen administered orally before, but not after immunization. Cell Immunol. 1995; 163:55-58.

Yoshino S. Downregulation of siliconeinduced chronic arthritis by gastric administration of type II collagen. Immunopharmlogy 1995; 31:103-108.

Yoshino S. Treatment with an anti-IL-4 monoclonal antibody blocks suppression of collagen-induced arthritis in mice by oral administration of type II collagen. J Immunol. 1998; 160(6):3067-71.

Zhang J, Markovic S, Raus J, Lacet B, Weiner HL, Hafler DA. Increased frequency of IL-2 responsive T-cells specific for myelin basic protein and proteolipid protein in peripheral blood and cerebrospinal fluid of patients with multiple sclerosis. J Exp Med. 1993; 179(3):973-84.

Zhang Y, Gilliam AC. Animal models for SSc: an update. Curr Rheumatol Rep. 2002; 4:150-62. 
VIII - Apêndices 
08-Jan-2007

Manuscript No. ADR-06-0138.R1

Title : COLLAGEN V NASAL TOLERANCE IN EXPERIMENTAL MODEL OF SYSTEMIC SCLEROSIS

By: Velosa, Ana Paula; Teodoro, Walcy; Oliveira, Cristiane; Santos Filho, Antonio; Moutinho, Rodnei; Santos, Angela; Vendramine, Margarete; Bueno, Cleonice; Parra, Edwin; Capelozzi, Vera; Yoshinari, Natalino

Dear Dr. Teodoro,

your manuscript ADR-06-0138.R1, entitled

"COLLAGEN V NASAL TOLERANCE IN EXPERIMENTAL MODEL OF SYSTEMIC SCLEROSIS",

is now accepted for publication in the Archives of Dermatological Research.

The manuscript will be forwarded to the publisher, from whom you will shortly receive information regarding the correction of proofs and fast online publication.

Please let Springer know as soon as possible, by return mail or by filling out the order form, if you wish to opt for Springer's Open Choice programme, which would make your article's online version available with open access. Detailed information about the Springer Open Choice option and an order form can be found at: www.springer.com/openchoice.

If you choose to participate in Open Choice you will be charged US $\$ 3000$ and your paper will be freely available with open access, ensuring the widest possible access to your research. Open Choice articles are also clearly indicated so users know about their enhanced access.

If you do not wish your article to be published with open access, no further action is necessary.

Should you have any questions regarding publication of your paper, please contact the responsible production editor, Ms.Ingrid Haas at ingrid.haas@springer.com.

Best wishes and thanks,

Prof. Ulrich Mrowietz

Editor-in-Chief

Archives of Dermatological Research 


\section{Archives of
Dermatological Springer
Research}

COLLAGEN V NASAL TOLERANCE IN EXPERIMENTAL MODEL OF SYSTEMIC SCLEROSIS

\begin{tabular}{|r|l|}
\hline Journal: & Archives of Dermatological Research \\
\hline Manuscript ID: & ADR-06-0138.R1 \\
\hline Type of Manuscript: & Original Paper \\
\hline Author: & 29-Nov-2006 \\
\hline Complete List of Authors: & $\begin{array}{l}\text { Velosa, Ana Paula; School of Medicine, University of São Paulo, } \\
\text { Discipline of Rheumatology } \\
\text { Teodoro, Walcy; School of Medicine, University of São Paulo, } \\
\text { Discipline of Rheumatology } \\
\text { Oliveira, Cristiane; School of Medicine, University of São Paulo, } \\
\text { Discipline of Rheumatology } \\
\text { Santos Filho, Antonio; School of Medicine, University of São Paulo, } \\
\text { Discipline of Rheumatology } \\
\text { Moutinho, Rodnei; School of Medicine, University of São Paulo, } \\
\text { Discipline of Rheumatology } \\
\text { Santos, Angela; School of Medicine, University of São Paulo, } \\
\text { Department of Pathology } \\
\text { Vendramine, Margarete; School of Medicine, University of São } \\
\text { Paulo, Discipline of Rheumatology } \\
\text { Bueno, Cleonice; School of Medicine, University of São Paulo, } \\
\text { Discipline of Rheumatology } \\
\text { Parra, Edwin; School of Medicine, University of São Paulo, } \\
\text { Department of Pathology } \\
\text { Capelozzi, Vera; School of Medicine, University of São Paulo, } \\
\text { Department of Pathology } \\
\text { Yoshinari, Natalino; School of Medicine, University of São Paulo, } \\
\text { Discipline of Rheumatology }\end{array}$ \\
\hline Keywords: & \begin{tabular}{l} 
collagen V, nasal tolerance, systemic sclerosis model, scleroderma \\
\hline
\end{tabular} \\
\hline \hline
\end{tabular}




\section{COLLAGEN V NASAL TOLERANCE IN EXPERIMENTAL MODEL OF SYSTEMIC SCLEROSIS}

Ana Paula Pereira Velosa ${ }^{(1)}$, Walcy Rosolia Teodoro ${ }^{(1)}$, Cristiane Carla de Oliveira $^{(1)}$, Antonio dos Santos Filho ${ }^{(1)}$, Rodnei Francisco Moutinho ${ }^{(1)}$, Angela Gomes Santos ${ }^{(2)}$, Margarete Borges Galhardo Vendramini( ${ }^{(1)}$, Cleonice Bueno ${ }^{(1)}$, Edwin Roger Parra ${ }^{(2)}$, Vera Luiza Capelozzi ${ }^{(2)}$, Natalino Hajime Yoshinari ${ }^{(1)}$

(1) Discipline of Rheumatology and (2) Department of Pathology from Faculty of Medicine, University of São Paulo

This study was supported by Fundação de Amparo à Pesquisa do Estado de São Paulo [FAPESP 2000/14336-0, FAPESP 2003/02543-0, CNPq- 300430/95-7] and Laboratório de Investigação Médica [Lim 17, Lim 05], School of Medicine, University of São Paulo, Brazil.

Running title: Type $V$ nasal tolerance in Scleroderma

Address for correspondence and reprint requests:

Natalino Hajime Yoshinari, MD, PhD

Disciplina de Reumatologia

Faculdade de Medicina da Universidade de São Paulo

Av. Dr. Arnaldo 455; cep - 01246-903, São Paulo, SP, Brasil.

phone - (5511)3061-7496; fax - (5511)3061-7490

e-mail - lyme@lim17.fm.usp.br

e-mail - matrix@lim17.fm.usp.br

e-mail -vcapelozzi@lim05.fm.usp.br 


\section{ABSTRACT}

Objective: Our aim was to study skin remodeling and autoantibody production in an experimental model of Scleroderma (SSc), following nasal tolerance with human type $\mathrm{V}$ collagen (Col V). Methods: Female New Zealand rabbits $(\mathrm{N}=12)$ were immunized with two doses of $1 \mathrm{mg} / \mathrm{ml}$ of Col $V$ in complete Freund's adjuvant and additional two boosters in incomplete Freund's adjuvant to induce SSc. After 150 days, half of from these immunized rabbits were submitted to type $V$ collageninduced tolerance receiving a daily nasal administration of $25 \mu \mathrm{g}$ of Col V. Control animals $(\mathrm{N}=6)$ were only submitted to type $\mathrm{V}$ collagen-induced tolerance. Serial skin biopsies were performed at 0,150 and 210 days, and stained with H\&E, Masson's trichrome and Picrosirius for morphological and morphometric analysis. Types I, III and V collagen were identified by immunofluorescence. The animals serum samples were collected to determine anti types I, III, IV and V collagen and antinuclear antibodies (ANA). Results: Skin biopsies from immunized animals confirmed SSc morphology as previously described, such as progressive decrease of papillary dermis, appendages atrophy, increased type I, III and V collagen deposition. Rabbits with Col V-induced nasal tolerance showed reduction of skin involvement, with significant decrease of collagen amount. Humoral immune response did not change with nasal tolerance. Conclusions: Col V nasal tolerance promotes regression of skin remodeling process in an experimental model of SSc. We suggest that nasal tolerance with type $\mathrm{V}$ collagen can be a promising therapeutic option to treat Scleroderma patients.

Key words: collagen V, nasal tolerance, systemic sclerosis model, Scleroderma 


\section{INTRODUCTION}

Systemic sclerosis (SSc) or scleroderma is a rheumatic disease, characterized by endothelium lesion, vascular fibrointima proliferation, matrix extracellular collagen deposition and autoantibody production, resulting in intense remodeling process with skin involvement and function loss of internal organs.

The pathogenesis of SSc is unknown, but recently the hypothesis that it could be an antigen-driven T cell disease has been more accepted [22]. According to this theory, $\mathrm{T}$ cells may be activated by unknown antigens and thus proliferate in a non-specific manner, promoting all the pathogenic aspects of SSc. The presence of oligoclonal T cells in skin biopsy specimens from patients with SSc [23] suggests that T-cell activation can be induced by a specific antigen [22].

In this respect, participation of many specific antigens has been proposed, such as HLA of fetal or maternal origin [4]; DNA topoisomerase I and other antibodies [13]; fibrillarin [3], centromere [31]; RNA polymerase and other nuclear antigens [19]; cytomegalovirus [18]; retrovirus [10].

Experimental models of SSc have been used in an attempt to understand its pathogenesis, but most of these models are obtained from genetically modified animals, such as naturally-occurring TSK-1 [21], UCD-200 chickens [24] or genetically manipulated animals through mutagenesis or genetic modifications [7]. Scleroderma-like lesions are also observed following chemical exposure to bleomycin [32] or transplantation of immune cells originating a graft-versus-host disease (GVHD) [38]. However, none of these conditions reproduce all the aspects observed in SSc [1]. 
We discovered that healthy female New Zealand rabbits immunized with human type $\mathrm{V}$ collagen (Col $\mathrm{V}$ ) plus Freund's adjuvant, develop progressive scleroderma-like lesions, characterized by endothelium damage (unpublished data), fibrosis $[6,28,29]$ and late presence of autoantibodies [37]. The same organs normally affected in patients with SSc are compromised in this experimental model $[6,28,29,36,37]$. Furthermore, there are strong histological and immunohistochemical similarities, when lung and skin tissues of immunized animals and patients with Ssc are compared $[6,29]$. These similarities were also observed when fibroblasts from skin and lungs of animals and patients with Ssc were cultured "in vitro" [26].

Another important discovery was the finding that fibroblasts of animals and patients with scleroderma synthesize structurally abnormal molecules of type $\mathrm{V}$ collagen [6]. As this molecule participates in fibrillogenesis process by helping to keep the integrity of the extracellular matrix and regulating the collagen fibril diameter [16], it is possible to hypothesize that the erroneous assembly of heterotypic fibrils, as a consequence of the presence of abnormal col $\mathrm{V}$, could be the main responsible factor for originating the altered extracellular matrix remodeling, observed in patients and animals immunized with Col V.

Collagen $\mathrm{V}$ is a component of the basement membrane and surrounds vascular smooth cells [16]. It is a very preserved protein found in many different animal species and it maintains the $\mathrm{NH} 2$ and $\mathrm{COOH}$ terminal ends, making this molecule more immunogenic [16]. Normally, this protein is not found exposed in the extracellular matrix, since it is found hidden among collagen types I and III fibrils, composing heterotypic fibers. 
In our previous manuscripts, we proposed that rabbit immunization with col $\mathrm{V}$ had probably exposed hidden self col $\mathrm{V}$, originating an experimental model of autoimmune disease resembling SSc $[6,28,29,36,37]$. This self antigen could perpetuate tissue damage, activating the immunological mechanisms and promoting lesions of organs normally compromised in SSc. So, it is possible to admit that Col $\mathrm{V}$ could can be one of the antigens responsible for T-cell activation, originating Th2 immune response with release of cytokines such as IL- 4, which induces fibrosis, endothelium damage and autoantibody production. For this reason, we decided to perform nasal tolerance with Col $V$ in this experimental model of scleroderma.

The aim of promoting mucosal tolerance is to suppress the specific immune reactivity, without affecting the entire immunologic system, by deleting or inactivating specific T-cell antigen driven clones. Nasal (or oral) administration of antigens is thought to lead to immune tolerance through one of two mechanisms, depending upon the dose used [8]. High doses of nasally administrated antigen lead to the deletion or anergy of Th cells, whereas a low dose leads to the induction of Th2 (IL-5, IL-10 and transforming growth factor (TGF)- $\beta$-secreting), TH3 (transforming growth factor (TGF)- $\beta$-secreting) and Tr1 (IL-10 and IL-4 secreting, but not TGF- $\beta$ ) regulatory cells $[8,11]$. Normally, T-regulatory cells maintain homeostasis in mucosal environments, with Tr1 cells predominating in the draining lymph nodes of the lung and Th3 cells predominating in the gut [2]. However, once activated by specific antigens, these T-regulatory cells suppress in an antigen-nonspecific manner, a phenomenon referred to as "bystander 
suppression" [17]. Since TGF- $\beta$ and IL-10 are potent immunosuppressants, capable of blocking $\mathrm{T}$ cell proliferation, mucosal tolerance to specific antigen involved in autoimmune diseases is being successfully used to treat animal models and human diseases [30].

We proposed to perform nasal tolerance with col $V$ protein in this new model, in an attempt to verify whether the main aspects of this disease, including skin fibrosis and antibody production, could be reverted with this therapeutic trial.

\section{METHODS}

\section{Scleroderma-like induction by immunization with type $V$ collagen}

Female New Zealand rabbits $(\mathrm{N}=12)$ were immunized with type $\mathrm{V}$ collagen $1 \mathrm{mg} / \mathrm{ml}$ in complete and/or incomplete Freund's adjuvant (Sigma Chemical Co.; St. Louis, Missouri, USA), as previously described $[6,28,29,36,37]$. The control group $(\mathrm{N}=6)$ was inoculated with complete and/or incomplete Freund's adjuvant, in a similar way to that used for immunization with collagen V. Animals from all groups were of the same age, with a mean weight of $2,500 \mathrm{~g}$.

\section{Induction of nasal tolerance by collagen $V$}

Nasal tolerance was induced in 6 rabbits immunized with type $\mathrm{V}$ collagen (COL $\mathrm{V}$ TOL) by daily nasal administrations of $25 \mu \mathrm{g}$ of the type $V$ collagen diluted in $25 \mu \mathrm{l}$ of acetic acid $10 \mathrm{mM}$. This first group started nasal tolerance at 150 days after the beginning of immunization, during 60 days. The second group was composed by six rabbits only immunized with type $\mathrm{V}$ collagen (Immunized group). The third group ( $\mathrm{N}=6)$ was inoculated with complete and incomplete Freund's adjuvant 
(Control group) and also nasally tolerated with type $V$ collagen after 150 days. All animals were sacrificed at 210 days.

\section{Skin biopsies}

Each animal was submitted to sequential skin biopsies from animal's dorsum region after anesthesia. A total of three biopsies, each one performed in a distinct region, were performed in all rabbits at 0 (before collagen $V$ immunization), 150 (before collagen $\mathrm{V}$-induced nasal tolerance) and 210 days after the beginning of immunization. The collected samples were immersed in 10\% formalin for 24 hours, embedded in paraffin, cut into 3 to $4-\mu \mathrm{m}$ thick sections and stained with hematoxylin-eosin (H\&E) and Masson's trichrome for morphological analysis. At day 210 all animals were anesthetized with $2 \%$ (2,6-xilidino) 5,6-dihidro-4H 1,3tiazin $1 \mathrm{M}$ (Rompum, Bayer do Brasil S. A) and euthanatized with lethal doses of Ketamin (Ketalar, Park-Davis) $1 \mathrm{M}$. The other organs, such as lung, heart, kidney, esophagus, synovia, aortic artery and articular cartilage were collected for future morphologic analysis.

\section{Morphometric analysis}

Collagen fibers were evaluated from the skin biopsies from all rabbits at 0, 150 and 210 days after the first immunization. For the collagen analysis, 3- $\mu m$ paraffinembedded sections were stained in a $0.2 \%$ solution of Sirius red (Direct Red 80, C. I. 35780 , Aldrich, Milwaukee, WI 53233, USA) dissolved in aqueous saturated picric acid [25]. The area occupied by collagen fibers in the skin compartments (papillary dermis, reticular dermis and deep dermis) were determined by optical 
density in the image analysis system in different randomly selected fields. The system used consists of a CCD Sony DXC-101 camera, applied to a Zeiss Axioplan microscope, from which the images are sent to a monitor (Trinitron Sony). By means of a digitizing system (Oculus TCX; Coreco Inc., St Laurent, Quebec, Canada) inserted into a computer (Pentium $133 \mathrm{MHz}$ ), the images were processed by a software (Imagen Pro-Plus). A total of 10 fields per case were analyzed at a magnification of $X 100$. The thresholds for collagen fibers were established for each slide, after enhancing the contrast up to a point at which the fibers were easily identified as birrefringent (collagen) bands. The area occupied by the fibers was determined by digital densitometric recognition, by adjusting the threshold level of measurement up to the different color densities of the collagen fibers. The area occupied by the fibers was divided by the total area of the field. The results express the skin area fraction occupied by the collagen fibers.

\section{Immunofluorescence assays for collagen I, III and V}

For collagen types I, III and V detection, the immunofluorescence of the animals' skin samples was performed in paraffin-embedded fragments mounted on slides with aminosylane (Sigma Chemical Co.; St. Louis, Missouri, USA). The slides were immersed in xylene and dehydrated in decreasing ethanol concentrations. The immunogenic sites were exposed by enzymatic treatment of the skin samples with bovine pepsin 4mg/ml (10,000 UTD; Sigma Co.; St. Louis, Missouri, USA) in acid buffer, $\mathrm{pH} 2.2$, for 30 min at $37^{\circ} \mathrm{C}$, followed by incubation in phosphate-buffered $5 \%$ milk, $\mathrm{pH}$ 7.0. The slides were incubated overnight at $4^{\circ} \mathrm{C}$ with polyclonal anticollagen types $\mathrm{I}$ and $\mathrm{V}$ antibodies obtained from mice and diluted 1:20 and 1:50, 
respectively in phosphate-buffered saline (PBS), and with monoclonal anti-collagen type III (Oncogen; San Diego, USA) diluted 1:50. After that, all slides were washed several times in PBS-0.05\% Tween 20 and incubated for 90 min with secondary antibody (fluorescein conjugated mouse anti-lgG, Sigma; St. Louis, Missouri, USA) diluted 1:50 in PBS containing $0.006 \%$ Evans blue. The slides were again washed several times in PBS-0.05\% Tween 20 and mounted with buffered glycerin. The reaction was visualized under a Nikon fluorescence microscope.

\section{Morphological study}

Histological Compartments. The skin was histologically divided into 3 anatomical compartments of reference: a) papillary dermis; b) reticular dermis; c) deep dermis. Histological changes in the 3 anatomical compartments were then analyzed for temporal evolutional regarding: 1.) type I, III and V immunostaining; 2.) the immunodetection pattern (homogeneous, heterogeneous); 3.) collagen fiber aspects (thin, thick, large, small).

Semi-Quantitative Assessment of Histological Changes. The severity of the histological changes in terms of extension, intensity and distribution were inhomogeneous along the anatomic compartments. Thus, the severity of these various histological changes was rated by a semi-quantitative method by two independent observers according to the amount and severity of disease according to the following histological score:

Score 1: when the histological changes were present in 1 to $30 \%$ of the dermis analyzed; 
Score 2: when the histological changes were present in 31 to $60 \%$ of the dermis analyzed;

Score 3: when the histological changes were present in 61 to $100 \%$ of the dermis analyzed.

\section{Serum collect}

Samples of blood were obtained from the ear artery of all rabbits, collected at 0,150 and 210 days after the first immunization and the sera were separated by centrifugation and kept frozen at minus $70^{\circ} \mathrm{C}$ until use.

\section{ELISA for collagen types I, III, IV and V}

Microtiter plates were coated with $50 \mu$ l of collagen types I, III, IV and V (Sigma, Chemical Co.; St. Louis, Missouri, USA) at a concentration of $5 \mu \mathrm{g} /$ well in bicarbonate buffer, $\mathrm{pH} 9,6$ and incubated overnight at $4^{\circ} \mathrm{C}$. Plates were blocked with 1\% BSA-PBS (Sigma, Chemical Co.; St. Louis, Missouri, USA) for 1 hour. Rabbit serum samples were diluted 1:100 into 1\% BSA-PBS with 0,05\% Tween 20 (Sigma, Chemical Co.; St. Louis, Missouri, USA.); duplicates at 50 $\mu$ l were added to the microtiter plates and incubated for 1 hour at room temperature. Plates were washed with PBS-Tween 20 and $50 \mu$ l of goat-anti-rabbit lgG alkaline phosphatase conjugated (Sigma, Chemical Co.; St. Louis, Missouri, USA) diluted 1:4000 into 1\% BSA-PBS with $0.05 \%$ Tween 20 was added to each well. The reaction was revealed by adding $50 \mu \mathrm{l} /$ well of $1 \mathrm{mg} / \mathrm{ml}$ p-nitrophenyl phosphate (pNPP) as substrate diluted in $1 \mathrm{M}$ diethanolamine, $0.5 \mathrm{mM} \mathrm{MgCl} 2, \mathrm{pH} 9.8$ buffer. The plates 
were read at $405 \mathrm{~nm}$ on a microplate reader (Labsystems Multiskan MS). The cutoff was determined based on the mean average plus 3 SD (standard deviation) of 8 normal serum samples. The results were expressed in arbitrary units (AU) as follows:

$$
\mathrm{AU}=\frac{\mathrm{OD} \text { sample }}{\text { Cut off }}
$$

\section{Anti-nuclear antibodies (ANA)}

Slides precoated with HEp-2 cells were used to evaluate the presence of ANA in all rabbits' serum samples. A FITC-conjugated goat-anti-rabbit IgG antibody (Sigma, Chemical Co.) at a 1:50 dilution was used as the secondary antibody. Slides were examined in a NIKON fluorescence microscope.

\section{Statistical analysis}

The quantitative results were expressed as means \pm SD. Sets of results were evaluated according to the temporal evolution and distribution of the morphological and serological alterations in immunized and collagen $\mathrm{V}$-induced nasal tolerance group and control rabbits. A descriptive analysis followed by the ANOVA test was applied to verify the differences of the means between and within groups and controls. When necessary, Bonferroni test was employed to identify differences among means. The significance level was set at 5\% [27]. 


\section{RESULTS}

\section{Histological analysis}

Histological evaluation of skin samples after HE and Masson's trichrome-staining before immunization at day 0 (Figures $1 \mathrm{~A}$ and $1 \mathrm{~B}$; Figures $2 \mathrm{~A}$ and $2 \mathrm{~B}$ ), was characterized by the maintenance of papillary dermis architecture and connective tissue, with preservation of the extracellular matrix. Equally preserved were cutaneous appendages (APP) and the adipose layer in the deep dermis. In contrast, at day 150 after the first immunization (Figure 1C and 1D; Figures 2D and 2E) and 210 (Figure 1E and 1F), the skin of immunized animals showed normal epiderme, but collagen bundles in the reticular dermis thickened and closely packed and stained deeply eosinophilic than in respective controls. In addition, the papillary dermis, where the collagen normally consists of loosely arranged fibers, the collagen appeared homogeneous. Also, the glands appeared markedly atrophic, and the fatty tissue normally surrounding them was greatly reduced in amount. This histologic pattern is usually found in human scleroderma.s. After 210 days, the skin samples from rabbits with col V-induced nasal tolerance presented increase of cutaneous appendages and decrease of collagen deposition (Figure $2 \mathrm{G}$ and $2 \mathrm{H}$ ), in comparison with the rabbits skin samples before tolerance (Figure 2D and 2E).

\section{Quantitative collagen analysis}

The collagen fibers birefringence from rabbits skins at 0 (Figure 2C), 150 (Figure $2 \mathrm{~F})$ and 210 days (Figure 2I) showed a decrease of collagen birefringence in the 
skin after rabbits' tolerance with type $\mathrm{V}$ collagen (Figure 2I) in comparison with the skin from rabbits before tolerance (Figure 2F).

Table 1 shows the quantitative analysis of the rabbits skins at 0,150 and 210 days from all groups. There was a statistically significant difference between control and immunized groups at 210 days $(p<0.01)$ and collagen $V$-induced nasal tolerance group and immunized group without type V-induced nasal tolerance at 210 days after immunization $(p=0.002)$ (Graphic 1).

Table 1 - Percentage of collagen fibers by area fraction in the rabbit skin of the control, immunized and COL V-TOL (type $\mathrm{V}$-induced tolerance group) groups

\begin{tabular}{|c|c|c|c|}
\hline GROUPS & 0 days & 150 days & 210 days ${ }^{*}$ \\
\hline $\begin{array}{c}\text { Control } \\
(n=6)\end{array}$ & $26 \% \pm 0,06$ & $32 \% \pm 0,02$ & $30 \% \pm 0,05$ \\
\hline$\underset{(n=6)}{\text { Immunized }}$ & $27 \% \pm 0,02$ & $38 \% \pm 0,05$ & $40 \% \pm 0,01$ \\
\hline $\begin{array}{c}\text { COL V-TOL } \\
(n=6)\end{array}$ & $23 \% \pm 0,02$ & $41 \% \pm 0,09$ & $31 \% \pm 0,02$ \\
\hline
\end{tabular}

\section{Immunostaining analysis}

The anti-collagen I immunostaining showed a homogeneous pattern of this protein detection in the sub-epidermic region and in the reticular dermis in all the control rabbits skin samples (Figures 3A, 3B, 3C and 3E). However, after 150 and 210 days of rabbits immunization (Figure $3 \mathrm{D}$ and $3 \mathrm{~F}$ ) type I collagen (COL I) was 
expressed in a dense heterogeneous pattern in the deep dermis, around the appendages (APP) and along the adipose layer. In the skins of type V-induced nasal tolerance rabbits (COL V-TOL group at 210 days, see Figures $3 G, 3 \mathrm{H}$ ) a homogeneous pattern was observed and characterized by a lower intensity of immunostaining around the appendages (APP) in the superficial and deep dermis. A thin fiber pattern of type III collagen (COL III) distribution was observed in the papillary region of the dermis in the skin of control rabbits (Figures 4A, 4B, 4C and 4E). In contrast, skin from immunized rabbits at 150 and 210 days showed a very strong expression of type III collagen (COL III), involving the entire superficial and deep dermis (Figures 4D and 4F). Type III collagen immunostaining was less expressed in the superficial and deep dermis of skin from type V-induced nasal tolerance rabbits (Figure $4 \mathrm{G}$ and $4 \mathrm{H}$ ). Type $\mathrm{V}$ collagen ( $\mathrm{COL} \mathrm{V}$ ), detected at a quantitatively lower percentage, showed a thin fiber pattern and was expressed in a non-significant manner in the basement membrane region in control rabbits (Figures $5 \mathrm{~A}, 5 \mathrm{~B}, 5 \mathrm{C}$ and $5 \mathrm{E}$ ). On the other hand, type $\mathrm{V}$ collagen (COL $\mathrm{V}$ ) was present in the shape of thick bundles along the papillary dermis and deep dermis in the skin of immunized rabbits (Figures $5 \mathrm{D}$ and $5 F$ ). This immunostaining pattern was changed after type $\mathrm{V}$-induced nasal tolerance, revealing a thin fiber pattern in the basement membrane and deep dermis (Figure $5 \mathrm{G}$ and $5 \mathrm{H}$ ).

\section{Semiquantitative collagen analysis}

The semiquantitative collagen analysis confirmed the results of the morphological study, by demonstrating the significant increase in the remodeling of the types I, III and $\mathrm{V}$ collagen, in the collagen $\mathrm{V}$ immunized and collagen $\mathrm{V}$-induced nasal 
tolerance groups, when compared with the control group (Graphic 2). At 150 days a significant increase of collagen between the control and immunized groups to the types I $(p<0.01)$, III $(p<0.01)$ and $V(p=0.019)$ collagen, as well in the control and collagen V-induced nasal tolerance groups to the types I ( $p=0.033)$, III $(p<0.01)$ and $V(p=0.020)$ collagen was observed. In contrast, at 210 days the skins of collagen V-induced nasal tolerance rabbits presented a significant decrease of types I $(p=0.002)$, III $(p=0.025)$ and $V(p=0.005)$ collagen in relation to the immunized group only (graphic 2 ).

\section{Determination of types I, III, IV and V antibodies}

The sera of the immunized and collagen $V$-induced nasal tolerance groups expressed significantly high levels of anti types III $(p<0.01)$, IV $(p<0.01)$ and V $(p<0.01)$ antibodies in relation to the control group at 150 and 210 days (Table 2). However, after type V-induced nasal tolerance, a statistical difference in anticollagen antibodies between the collagen $\mathrm{V}$-induced nasal tolerance and immunized groups was not observed (Table 2). Antibodies directed to collagen type I were not statistically significant in all the studied groups. 
Table 2 - Anti types I, III, IV and V collagen antibodies levels in the sera of the control, immunized and COL V-TOL (type $\mathrm{V}$-induced nasal tolerance) groups

\begin{tabular}{|c|c|c|c|c|c|}
\hline Groups & Days & Anti I & Anti III & Anti IV & Anti V \\
\hline $\begin{array}{l}\text { Control } \\
(n=6)\end{array}$ & $\begin{array}{c}0 \\
150 \\
210\end{array}$ & $\begin{array}{c}0,37 \pm 0,21 \\
0,38 \pm 0,14 \\
0,4 \pm 0,16\end{array}$ & $\begin{array}{l}0,28 \pm 0,05 \\
0,22 \pm 0,14 \\
0,32 \pm 0,19\end{array}$ & $\begin{array}{l}0,42 \pm 0,21 \\
0,69 \pm 0,53 \\
0,38 \pm 0,28\end{array}$ & $\begin{array}{l}0,32 \pm 0,06 \\
0,22 \pm 0,07 \\
0,45 \pm 0,37\end{array}$ \\
\hline $\begin{array}{l}\text { Immunized } \\
\qquad(n=6)\end{array}$ & $\begin{array}{c}0 \\
150 \\
210\end{array}$ & $\begin{array}{l}0,23 \pm 0,04 \\
0,67 \pm 0,20 \\
0,76 \pm 0,38\end{array}$ & $\begin{array}{c}0,31 \pm 0,09 \\
19,64 \pm 1,32^{*} \\
18,03 \pm 1,49^{*}\end{array}$ & $\begin{array}{c}0,31 \pm 0,50 \\
16,67 \pm 2,14^{*} \\
16,54 \pm 1,29^{*}\end{array}$ & $\begin{array}{c}0,36 \pm 0,24 \\
5,79 \pm 1,52^{*} \\
5,07 \pm 1,19^{*}\end{array}$ \\
\hline $\begin{array}{c}\text { COL V-TOL } \\
\qquad(n=6)\end{array}$ & $\begin{array}{c}0 \\
150 \\
210\end{array}$ & $\begin{array}{l}0,29 \pm 0,20 \\
1,44 \pm 1,54 \\
0,92 \pm 0,81\end{array}$ & $\begin{array}{c}0,33 \pm 0,06 \\
18,13 \pm 3,17^{* *} \\
16,73 \pm 4,05^{* *}\end{array}$ & $\begin{array}{c}0,15 \pm 0,11 \\
12,54 \pm 2,6^{* *} \\
11,35 \pm 2,85^{* *}\end{array}$ & $\begin{array}{c}0,28 \pm 0,09 \\
6,06 \pm 1,59^{* *} \\
5,35 \pm 1,62^{* *}\end{array}$ \\
\hline
\end{tabular}

\section{Determination of antinuclear antibodies (ANA)}

Almost all animal presented antibodies directed to cytoplasmic antigens after immunization with type $\mathrm{V}$ collagen. The immunized animals showed two patterns: one was characterized by fine cytoplasmic immunofluorescence staining, close to the nuclear membrane; the other pattern revealed the presence of dense dotted staining. The last staining pattern was more frequent in the immunized animals group at 210 days than that observed in the collagen $\mathrm{V}$-induced nasal tolerance group. 


\section{DISCUSSION}

This study was proposed in order to verify whether type $\mathrm{V}$ collagen nasal tolerance was able to suppress morphological and immunological alterations observed in rabbits immunized with type $\mathrm{V}$ collagen. This alternative therapeutic trial, if successfully conducted, could constitute a promising treatment for Scleroderma patients.

Recently, type $V$ collagen has been considered a potential self antigen; capable of promoting autoimmune disease $[6,28,29,36,37]$ or graft-versus-host disease $[9,15,34,35]$. Our group has shown that rabbits immunized with human type $\mathrm{V}$ collagen, in an attempt to produce the corresponding antibodies, developed remodeling process due to collagen deposition in vessels and lung parenchyma, as well as in other organs similar to human SSc. Interestingly, Wilkes group concomitantly discovered that type $\mathrm{V}$ collagen was the antigen responsible for lung allograft rejection in a murine model of transplantation $[9,15]$. According to them, the inflammatory process generated during organ rejection phenomenon had promoted the exposition of hidden self type $\mathrm{V}$ collagen, originating a graft-versus host disease directed to the epitopes of this molecule. Furthermore, the same group demonstrated that oral tolerance with collagen $V$ prevented the onset of acute lung allograft rejection, blocking the development of bronchiolitis obliterans, the main causative factor of death following mice and human lung transplants $[34,35]$.

Broad evidence encouraged us to carry out a study on nasal tolerance with collagen $\mathrm{V}$ in an experimental model induced by type $\mathrm{V}$ collagen: 1- existence of similarities between graft-versus-host disease and SSc [5]; 2- strong evidence that 
SSc is an antigen-driven T-cell disease [22]; 3- prevention of lung allograft rejection by oral tolerance with type $\mathrm{V}$ collagen [34]. The analysis of these points led us to think that a hidden self protein, perhaps collagen $V$ fragments, could be involved in triggering SSc, via T-cell activation by specific antigen.

At the first time, in the present study two of six rabbits immunized with type V collagen developed macroscopic skin lesions, characterized by localized coat loss, with the presence of multiple reddish maculated lesions on the exposed areas (data not shown). This manifestation was probably not previously observed because the animals had never been followed until 210 days after the beginning of immunization. In fact, histological analysis confirmed that immunized animals presented progressive rectification of epidermis, decrease of papillary dermis, appendage atrophy and collagen deposition in the reticular and deep dermis. On the other hand, tolerated rabbits exhibited reversal aspects, such as increase of cutaneous appendages and decrease of collagen amount, when compared with animals prior to tolerance. Moreover, quantitative skin collagen analysis, demonstrated that there was a significant difference between control and immunized animals at 210 days after the beginning of immunization. Additionally, tolerated rabbits showed significant decrease of collagen contents, when compared with immunized animals at 210 days. Collagen immunostainning showed increased collagen types I, III and V depositions in the skin of immunized rabbits at 150 and 210 days, when compared with control animals. Nasally tolerated animals expressed a significant lower quantity of collagen types I, III and V. Interestingly enough, abnormal immunostaining of type $\mathrm{V}$ collagen, observed in immunized animals, had reversed after nasal tolerance with type $V$ collagen, 
exhibiting a thin fiber pattern in the basement membrane and deep dermis. Furthermore, rabbits immunized with Freund's adjuvant and nasally tolerated with collagen $\mathrm{V}$ for two months did not present any morphological changes. In addition, immunized rabbits expressed ANA and anticollagen types III and IV antibodies in the serum, as previously demonstrated [37]. The presence of antibodies directed to collagen types IV and V, previously reported in patients with SSc [20], is very suggestive evidence of basement membrane injury. The inflammatory and immunological aggressions directed to type $\mathrm{V}$ collagen located just beneath the basement membrane probably contributed to basement membrane injury, leading to further exposition of collagen IV for the immunological system. Apparently, nasal tolerance did not interfere with antibody production, perhaps due to the short follow-up period. It is usually accepted that suppression of the humoral immune response following tolerance mechanisms is delayed.

We have also found that rabbits with scleroderma-like lesions and collagen V-induced nasal tolerance revealed minor deposition of structurally normal collagen associated with low expression of TGF- $\beta$ and PDGF (data not shown). Surprisingly, nasal tolerance leads to synthesis of structurally normal type $\mathrm{V}$ collagen. According to our opinion, correction of the abnormal synthesis of this molecule, responsible for the histoarchitectural tissue disarrangement observed in SSc, reverted the altered remodeling of extracellular matrix. Many researchers have described abnormalities within the TGF- $\beta$ signaling pathway in scleroderma [14]. Again we emphasize the role of Col V epitopes in the pathogenesis of SSc, which acts as an antigen to activate the $\mathrm{T}$ cell cascade, especially Th2 cell 
population, with the release of pro-fibrotic cytokines such as IL-4, IL-5 and IL-13. Additionally, IL-4 cytokine induces the synthesis of TGF- $\beta$ [12], which is expressed in mononuclear cells, endothelial cells and fibroblasts.

We suggest that the decreased synthesis of the types I, III and V collagen and fibrotic cytokines (TGF- $\beta$ and PDGF) in the rabbits skin after nasal tolerance with type $\mathrm{V}$ collagen, was related to the induction of $\operatorname{Tr} 1$ regulatory cells, as these cells predominate in the draining lymph nodes of the lung [2]. It is known that Tr-1 regulatory cells produce high amounts of IL-10, a potent immunosuppressant capable of preventing the development of $\mathrm{T}$ cell-mediated autoimmune responses [11]. On the other hand, previous studies demonstrated that collagen I and fibronectin mRNAs from scleroderma skin fibroblasts were downregulated by IL-10 [33].

Based on our results, we hypothesized that type $\mathrm{V}$ collagen could be one of the possible specific antigens to trigger T-cell immune response in SSc. Environmental factors could promote endothelium and basement membrane injury with further exposition of self antigens, such as collagen $\mathrm{V}$, which could trigger specific T-cell mediated immune response. In this context, exposition of these hidden antigens may be associated with infection by cytomegalovirus, contact with bleomycin or vinyl chloride, graft-versus-host disease and transplantation of mismatched immune cells. Interestingly, nasal tolerance with Col $\mathrm{V}$ reverted endothelium apoptosis (data not shown), possibly the main pathogenic factor, responsible for the perpetuation of the remodeling phenomenon observed is scleroderma. 
We conclude that this experimental model of SSc, induced by type $\mathrm{V}$ collagen, is possibly a specific antigen-driven T-cell disease, induced by self antigens, generated during prolonged aggression against the endothelium and extracellular matrix components. One of the proposed self antigens is type $\mathrm{V}$ collagen, but we cannot rule out the participation of other hidden self proteins, possibly exposed during prolonged inflammatory processes, inducing specific Tcell immune responses. Based on this hypothesis, we demonstrated that nasal tolerance with collagen $\mathrm{V}$ induced the histological regression of the main features observed in an experimental model of SSc. As the present experimental model of Ssc and the disease in humans share strong similarities, we consider nasal tolerance with Col $\mathrm{V}$ a promising therapeutic option for the control of this severe disease.

\section{Acknowledgments}

This study was supported by the following Brazilian agencies: Foundation for the Support of Research of the State of São Paulo (FAPESP) and Laboratories for Medical Research (LIMs), University Hospital, School of Medicine, University of São Paulo. We thank Cassia Arruda for preparing the skin slides. 


\section{REFERENCES}

1. Abraham DJ and Varga J (2005) Scleroderma: from cell and molecular mechanisms to disease models. Autoimmunity Spec Iss 26(11): 587-595

2. Akbari O, Dekruyff RH, Umetsu DT (2001) Pulmonary dentritic cells producing IL-10 mediate tolerance induced by respiratory expore to antigen. Nat Immun 2: 725-731

3. Arnett FC, Reveille JD, Goldstein R, Pollard KM, Leaird K, Smith EA, Leroy EC, Fritzler MJ (1996) Autoantibodies to fibrillarin in systemic sclerosis (scleroderma): an immunogenetic, serologic, and clinical analysis. Arthritis Rheum 39: 1151-1160

4. Artlett CM, Cox LA, Jimenez SA (2000) Detection of cellular microchimerism of male origin in systemic sclerosis patients by polymerase chain reaction analysis of HLA-Cw antigens. Arthritis Rheum 43: $1062-1066$

5. Bell SA, Faust H, Mittermuller J, Kolb HJ, Meurer M (1996) Specificity of antinuclear antibodies in scleroderma-like graft versus host disease: clinical correlation and histocompatibility locus antigen association. $\mathrm{Br} \mathrm{J}$ Dermatol 134: 848-854

6. Bezerra MC, Teodoro WR, Oliveira CC, Velosa APP, Ogido LTI, Gauditano G, Parra ER, Capelozzi VL, Yoshinari NH (2006) Scleroderma-like remodelling induced by type $\mathrm{V}$ collagen. Arch Dermatol Res 298(2): 51-57

7. Clark SH (2005) Animal models in SSc. Rheumatol Rep 7: 150-155 
8. Faria AMC and Weiner $H$ (1999) Oral tolerance: Mechanisms and therapeutic Applications. Advanc Immunol 73: 153-264

9. Haque MA, Myzobuchi T, Yasufuku K, Fujisawa T, Brutkiewiez RR, Zeng Y, Woods K, Smith GN, Cummings OW, Heidler KM, Wilkes DS (2002) Evidence for immune responses to a self antigen in lung transplantation: role of type $\mathrm{V}$ collagen-specific $\mathrm{T}$ cells in the pathogenesis of lung allograft rejection. J Immunol 169: 1542-1549

10. Jimenez SA, Batuman O (1993) Immunopathogenesis of systemic sclerosis: possible role of retroviruses. Autoimmunity 16: 225-233

11. Jonuleit H and Schmitt E (2003) The Regulatory T cell family: Distinct subsets and their interrelations. J Immunol 171(12): 6323-6327.

12. Kodera T, McGaha TL, Phelps R, Paul WE, Bona CA (2002) Disrupting the IL-4 gene rescues mice homozygous for the tight-skin mutation from embryonic death and diminishes TGF- $\beta$ production by fibroblasts. Proc Natl Acad Sci USA 99: 3800-3805

13. Kuwana M, Kaburaki J, Okano Y, Inako H, Tsuji K (1993) The HLA_DR and DQ genes control the autoimmune response to DNA topoisomerase I in systemic sclerosis (scleroderma) J Clin Invest 92: 1296-1301

14. Leask A and Abraham (2004) TGF- $\beta$ signaling and the fibrotic response. FASEB J 18: 816-827

15. Mares DC, Heidler KM, Smith GN, Cummings OW, Harris ER, Foreman BH, Wilkes DS (2000) Type V collagen modulates alloantigen-induced 
pathology and immunology in the lung. Am J Respir Cell Mol Biol 23: 6270.

16. Mayne R, Burgeson R (1993) Structure and function of collagen types. In: Ulecham R (ed) Biology of Extracellular Matrix, 20th ed., Academic Press, London, pp 1-37

17. Miller A, Lider O, Weiner HL (1991) Antigen-driven bystander suppression after oral administration of antigens. J Exp Med 174: 791798

18. Neidhart M, Kuchen S, Distler O, Bruhlman P, Michel BA, Gay R, Gay S (1999) Increased serum levels of antibodies against human cytomegalovirus and prevalence of autoantibodies in systemic sclerosis. Arthritis Rheum 42: 389-392

19. Overzet K, Gensler TJ, Kim SJ, Geiger ME, van Verooij WJ, Pollard KM, Anderson P, Utz PJ (2000) Small nucleolar RNP scleroderma autoantigens associate with phosphorylated serine/arginine spicing factors during apoptosis. Arthritis Rheum 43: 1327-1336

20. Riente L, Marchini B, Dolcher MP, Puccetti A, Bombardieri S, Migliorini P (1995) Anti-collagen antibodies in systemic sclerosis and primary Raynaud's phenomenon. Clin Exp Immunol 102(2): 354-359

21. Saito E, Fujimoto M, Hasegawa M, Komura K, Hamaguchi Y, Kaburagi Y, Nagaoka T, Takehara K, Tedder TF, Saito S (2002) CD19-dependent B lymphocyte signaling thresholds influence skin fibrosis and autoimmunity in the tight-skin mouse. J Clin Invest 109: 1453-1462 
22. Sakkas LI, Platsoucas CD (2004) Is systemic sclerosis an antigen-driven T cell disease? Arthritis Rheum 50(6): 1721-1733

23. Sakkas LI, Xu B, Artlett CM, Lu S, Jimenez SA, Platsoucas CD (2002) Oligoclonal $\mathrm{T}$ cell expression in the skin of patients with systemis sclerosis. J Immunol 168: 3649-3659

24. Sgonc R (1999) the vascular perspectives of systemic sclerosis: of chickens, mice and men. Int Arch Allergy Immunol 120: 169-176

25. Shapiro SD, Endicott SK, Province MA, Pierce JA, Campbell EJ (1991) Marked longevity of human lung parenchymal elastic fibers deduced from prevalence of D-aspartate and nuclear weapons-related radiocarbon. J Clin Invest 87: 1828-1834

26. Souza RBC, Borges CTL, Capelozzi VL, Carrasco S, Velosa APP, Teodoro WR, Goldenstein-Schainberg C, Yoshinari NH (2005) Abnormal Type $\mathrm{V}$ collagen Deposition in Lung Fibroblast is Correlated with a Worse Pulmonary Capacity in Scleroderma (SSc). Arthritis Rheum 52(9): s177

27. SPSS Statistical software (2002) Version 10.0. SPSS Inc, Chicago

28. Teodoro WR, Miron BG, Ogido LT, Velosa APP, Abatepaulo F, Capelozzi VL, Yoshinari NH (2003) Synovial remodelling process induced by type $\mathrm{V}$ collagen immunization in rabbits. Pathol Res Pract 199: $605-612$

29. Teodoro WR, Velosa APP, Witzel SS, Garippo AL, Farhat C, Parra ER, Sonohara S, Capelozzi VL, Yoshinari NH (2004) Architectural remodelling in lungs of rabbits induced by type $\mathrm{V}$ collagen immunization: 
a preliminary morphologic model to study diffuse connective tissue diseases. Pathol Res Pract 200: 681-91

30. Wolfraim LA (2006) Treating autoimmune diseases through restoration of antigen-specific tolerance. Arch Immunol Ther Exp 54: 1-13

31. Xu S-W, Panesar M, Vanchesswaran R, Mason J, Haskard D, Black C, et al. (1994) Expression and shedding of intercellular adhesion molecule 1 and lymphocyte function-associated antigen 3 by normal and scleroderma fibroblasts: effect of interferon- $\gamma$, tumor necrosis factor $\alpha$, and estrogen. Arthritis Rheum 37: 1689-1697

32. Yamamoto $T$ and Nisshioka $K$ (2005) Cellular and molecular mechanisms of bleomycin-induced murine SSc: current update and future perspective. Exp Dermatol 14: 81-95

33. Yamamoto T, Eckes B, Krieg T. (2001) Effect of interleukin-10 on the gene expression of type I collagen, fobronectin, and decorin in human skin fibroblasts: differential regulation by transforming growth factor- $\beta$ and Monocyte chemoattractant protein-1. Biochem Biophysic Res Comm 281: $200-205$

34. Yasufuku K, Heidler KM, O’Donell PW, Cummings OW, Foreman BH, Fujisawa T, Wilkes DS (2001) Oral tolerance induction by type V collagen Downregulates lung allograft. Am J Respir Cell Mol Biol 25(1): $26-34$

35. Yasufuku K, Heidler KM, Woods KA, Smith GN Jr, Cummings OW, Fujisawa T, Wilkes DS (2002) Prevention of bronchiolitis obliterans in rat 
lung allografts by type $\mathrm{V}$ collagen-induced oral tolerance. Transplantation 73: $500-505$

36. Yoshinari NH, Teodoro WR, Ogido LTI, Velosa APP, Prizon CP, Miron B, Bissoli JCC, Cuentas ERP, Capelozzi VL (2002) Modelo experimental de doenças difusas do tecido conjuntivo (DDTC) induzido por colágeno do tipo V. Rev Bras Reumatol 42: 295-305

37. Yoshinari NH, Callado MR, Velosa APP, Viana VTS, GoldeinsteinSchainberg C, Carrasco S, Bezerra MC, Ogido LT, Oliveira CC, Capelozzi VL, Teodoro WR (2005) Experimental Model of Scleroderma Induced in Rabbits. Arthritis Rheum 52(9): s369

38. Zhang Y and Gilliam AC (2002) Animal models for SSc: an update. Curr Rheumatol Rep 4: 150-162 


\section{Legends}

Figure 1 - Skin section of immunized rabbits at 0,150 and 210 days after immunization stained with H\&E (left side) and Masson's trichromic (right side). In A and $B$, skin of rabbit at 0 days (before immunization) showing maintenance of papillary dermis architecture, connective tissue and preserved cutaneous appendages (APP). In contrast, at 150 (C and D) and 210 (E and F) days after the first immunization, the skin of immunized animals showed linear modification of epidermis and progressive decrease of papillary dermis, appendage atrophy and collagen deposition in the reticular and deep dermis, as well as around blood vessels and appendages, modifying the conformation of the latter to a Scleroderma pattern (Original magnification X100, A-F; H\&E staining A, C and E; Masson's trichromic staining $B, D$ and $F$ ).

Figure 2 - Skin section of rabbits stained with H\&E (left side), Masson's trichromic (middle) and Sirius red (right side). In A, B and C, skin from animal at 0 days (before immunization) shows maintenance of papillary dermis architecture and connective tissue, with preservation of the extracellular matrix, presence of many cutaneous appendages (APP) and the adipose layer in the deep dermis. In D, E and $F$, skin from immunized rabbits at 150 days after immunization (before tolerance) shows linear modification of epidermis and decrease of papillary dermis, appendage atrophy and collagen deposition in the reticular and deep dermis, as well as around blood vessels and appendages, similar to the Scleroderma pattern. In $\mathrm{G}, \mathrm{H}$ and I, skin from tolerated animal at 210 days shows the presence of more cutaneous appendages and decrease of collagen when compared to the rabbits' 
skins before tolerance (Original magnification X40, A-I; H\&E staining A, D and G; Masson's trichromic staining B,E and H; Sirius red staining $C, F$ and I).

Figure 3 - Immunofluorescence to type I collagen in skin section of control, immunized and tolerated rabbits. In A, C and E, skins from control animal at 0, 150 and 210 days, respectively, show a homogeneous pattern of type I collagen in the sub-epidermic region and in the reticular dermis in all control rabbits. In $\mathrm{B}$, $\mathrm{a}$ pattern similar to control of type I collagen in skin of immunized rabbit at 0 days (before immunization) was observed. In D and F, type I collagen from immunized rabbits after 150 and 210 days, respectively, expressed a dense heterogeneous pattern in the deep dermis, around the appendages and along of the adipose layer. In $\mathrm{G}$ and $\mathrm{H}$, type I collagen from tolerated rabbit shows a homogeneous pattern, lower intensity of immunostaining around the appendages, in the superficial and deep dermis, similar to the control group (Original magnification $\mathrm{X} 100, \mathrm{~A}-\mathrm{H}$ ).

Figure 4 - Immunofluorescence to type III collagen in skin section of control, immunized and tolerated rabbits. In A, C and E, skins from control animals at 0 , 150 and 210 days, respectively, show a thin fiber pattern of type III collagen (COL III) distribution, in the papillary region of the dermis. In B, a similar pattern to control of type III collagen in skin of immunized rabbit was observed at 0 days (before immunization). In D and F, type III (COL III) collagen from immunized rabbits after 150 and 210 days, respectively, shows a very strong expression in the superficial and deep dermis. In $\mathrm{G}$ and $\mathrm{H}$, skin from tolerated rabbit shows type III collagen 
immunostaining less expressed in the superficial and deep dermis. (Original magnification $\times 100, A-H)$.

Figure 5 - Immunofluorescence to type $V$ collagen in skin section of control, immunized and tolerated rabbits. In A, C and E skin from control animals at 0,150 and 210 days, respectively, show a low expression of type $V$ collagen (COL V), a thin fiber pattern in the basement membrane region. In $\mathrm{B}$, a similar pattern to control of type $\mathrm{V}$ collagen in skin of immunized rabbit at 0 days (before immunization) was observed. In $\mathrm{D}$ and $\mathrm{F}$, type $\mathrm{V}$ collagen from immunized rabbits after 150 and 210 days, respectively, show a pattern of thick bundles along the papillary dermis and deep dermis. In $\mathrm{G}$ and $\mathrm{H}$, skin from tolerated rabbits shows that the type $\mathrm{V}$ immunostaining pattern changed after nasal tolerance, revealing a thin fiber pattern in the basement membrane region and deep dermis. (Original magnification $\mathrm{X} 100, \mathrm{~A}-\mathrm{H})$. 

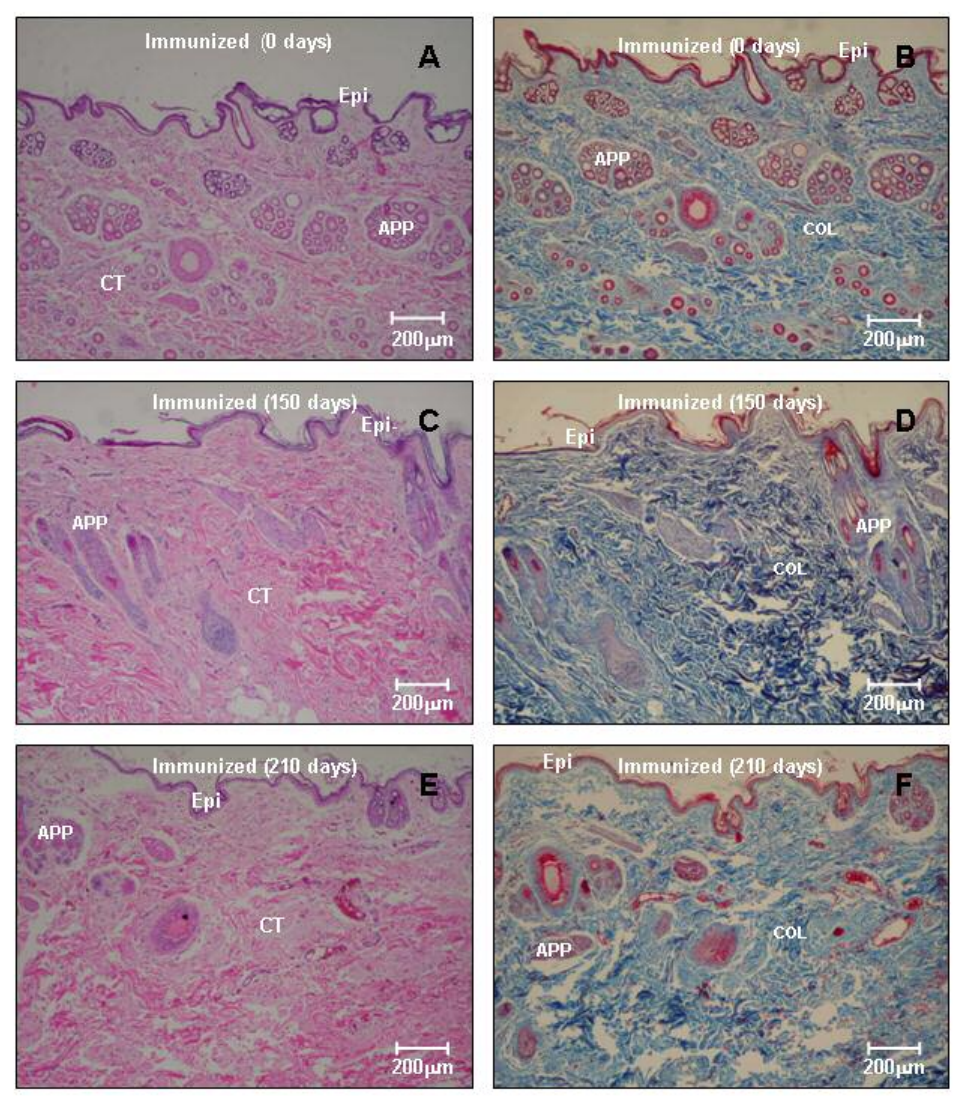

Figure 1

Fig.1 


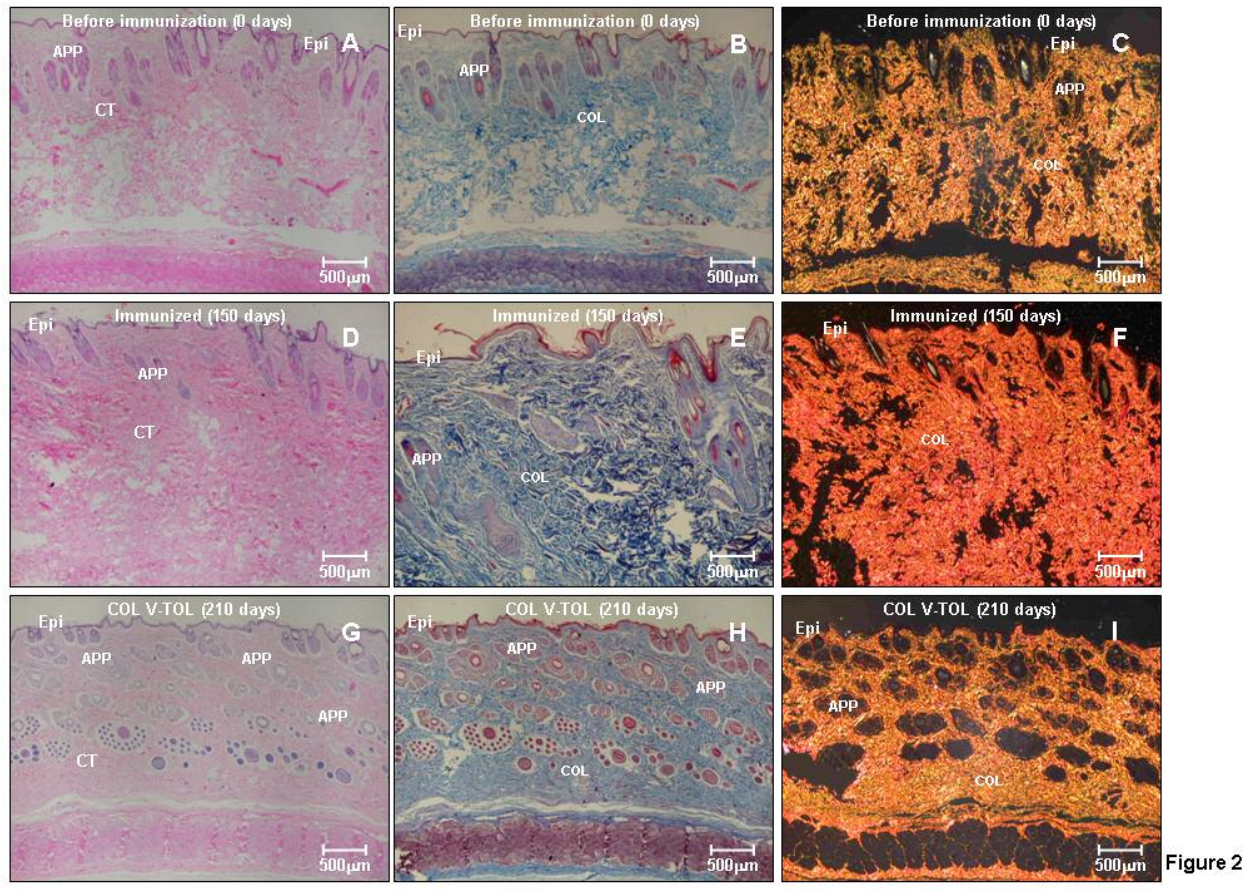



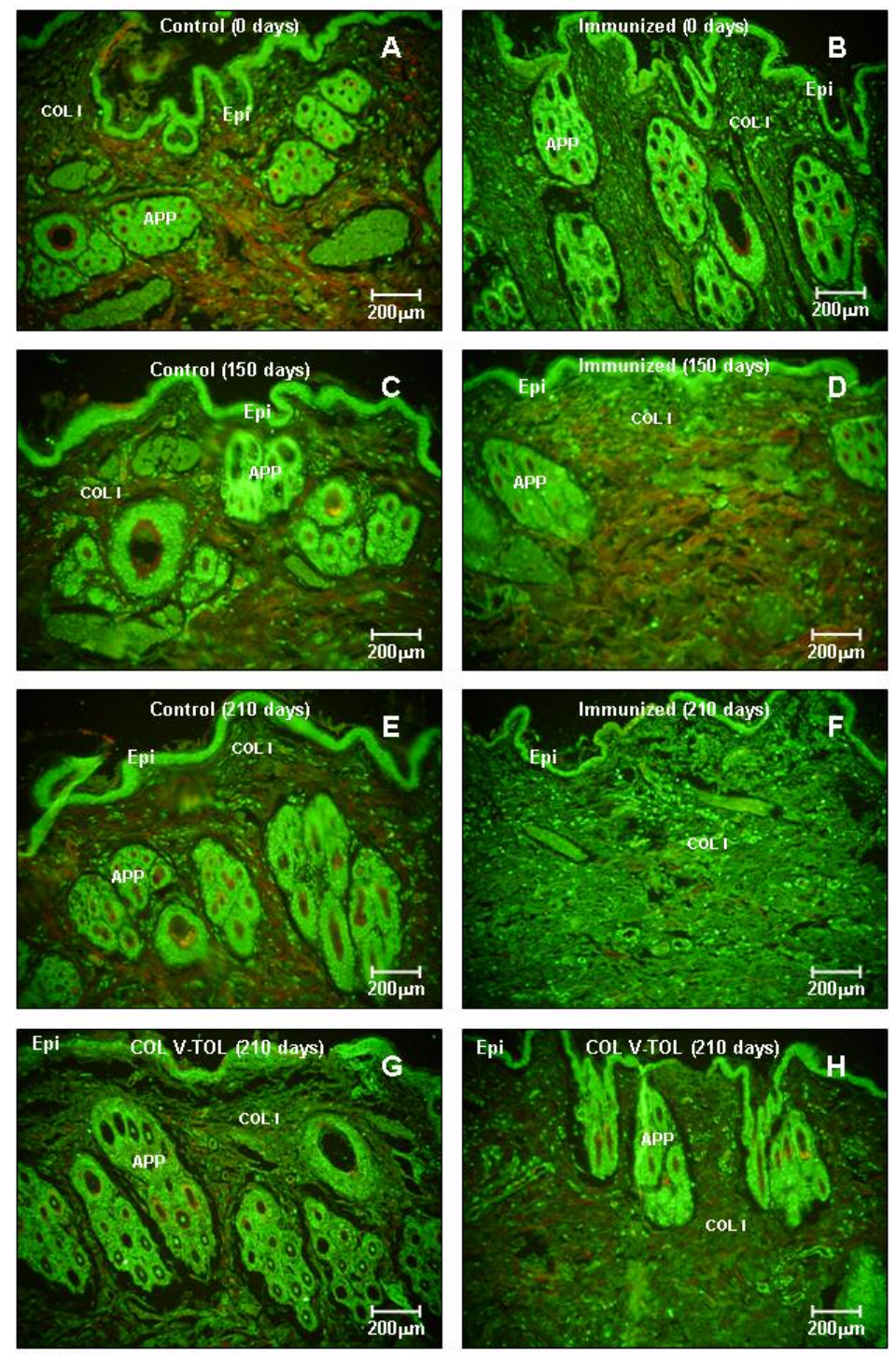

Figure 3 

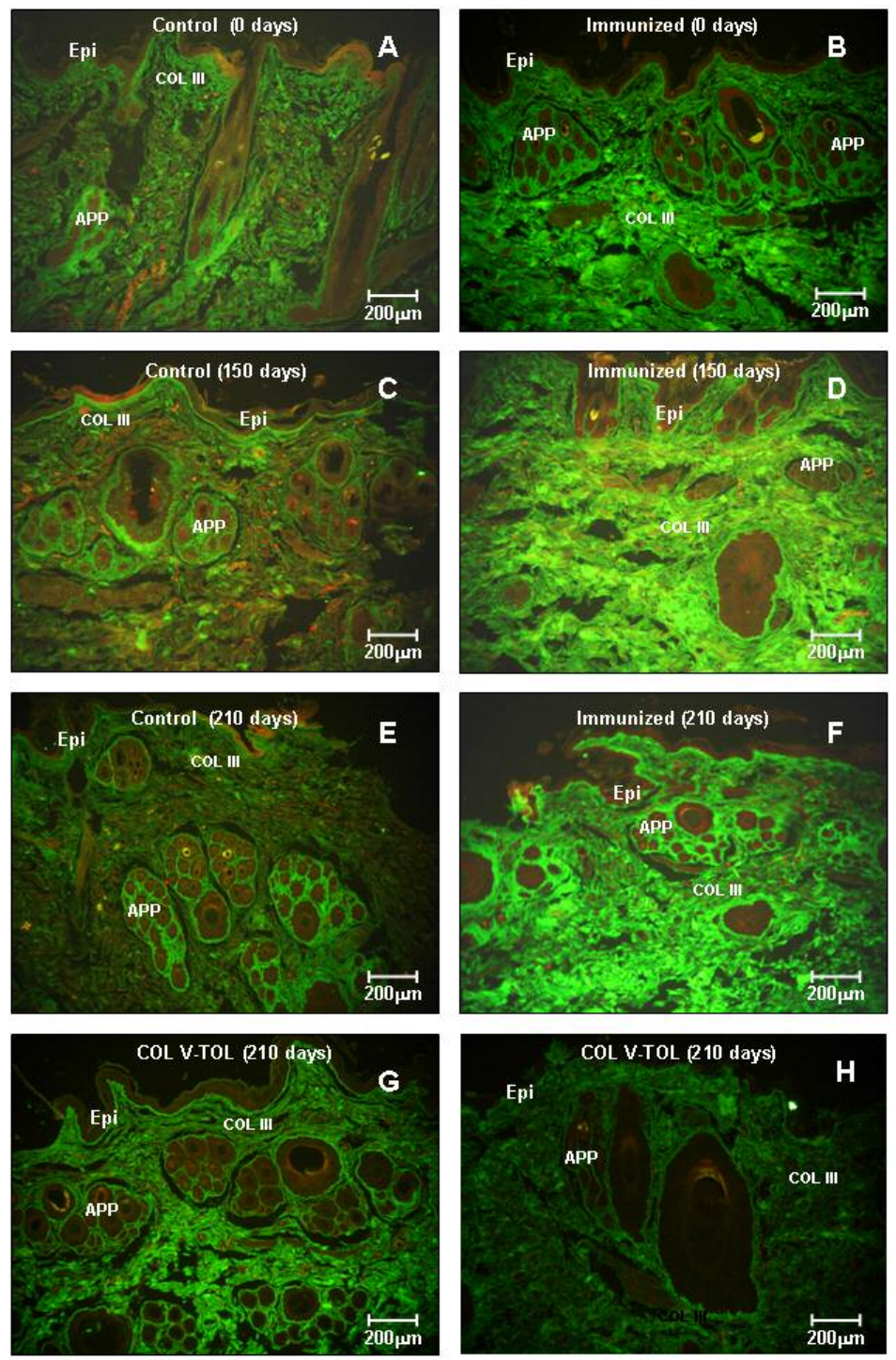

Figure 4 



Figure 5 